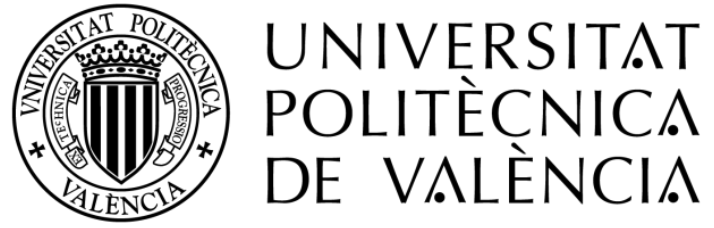

\title{
EFFECT OF FEED RESTRICTION IN A RABBIT LINE SELECTED FOR GROWTH RATE ON REPRODUCTIVE PERFORMANCE: OVULATION INDUCTION, OOCYTE QUALITY, \\ EMBRYONARY AND FETAL LOSSES
}
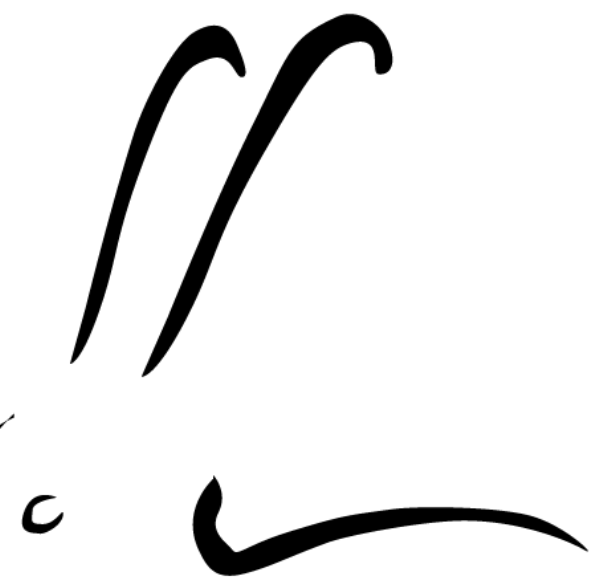

Ph.D Thesis by

Carmen Naturil Alfonso

Supervisors

Prof. Francisco Marco Jiménez Prof. José Salvador Vicente Antón 



\title{
UNIVERSITAT POLITÈCNICA DE VALÈNCIA
}

\author{
EFFECT OF FEED RESTRICTION IN A RABBIT LINE SELECTED FOR \\ GROWTH RATE ON REPRODUCTIVE PERFORMANCE: OVULATION \\ INDUCTION, OOCYTE QUALITY, EMBRYONARY AND FETAL \\ LOSSES
}

A thesis submitted to the Polytechnic University of Valencia in partial fulfilment of the requirements for the degree of doctor of philosophy

By

\section{Carmen Naturil Alfonso}

Sig.

Thesis Directors

Dr. Francisco Marco Jiménez

Dr. José Salvador Vicente Antón

Sig.

Sig. 



\title{
ABSTRACT/RESUMEN/RESUM
}

\author{
C. Naturil-Alfonso
}

Instituto de Ciencia y Tecnología Animal, Laboratorio de Biotecnología de la Reproducción, Universidad Politécnica de Valencia, Valencia, 46022 

The general aim of this thesis was to reproductively characterize females from a rabbit line selected for growth rate (line R) and to evaluate the effect of different nutritional strategies (ad libitum and restricted before reproduction), in order to improve the reproductive performance of these females.

In chapter 1, the influence of maternal and embryonic genotype on prenatal survival and fetal growth over gestation was evaluated and contrasted with a maternal line. Prenatal survival, fetal weight and fetal placenta weight were affected by both embryonic and maternal genotype. Firstly, embryonic genotype was a main factor at Days 14 and 24 and maternal genotype contributed at Day 30 of prenatal survival. Secondly, differences in fetal weight were only manifested at Day 14, the embryonic/maternal genotype from the maternal line being the heaviest $(0.29 \pm 0.01 \mathrm{~g}$ vs. $0.19 \pm 0.01 \mathrm{~g}$, for line $\mathrm{R}$ genotypes). However, while for fetal placenta weight both genotypes showed an effect at Day 24, for maternal placenta weight they were relevant at Day 30. Nevertheless, no differences were detected either at transcriptomic level in fetal placenta or in progesterone and IGF-I plasma levels in these females. From this chapter it may be concluded that in rabbit females from paternal lines both embryonic and maternal genotypes are key factors in the reproductive performance of these females.

The aim of chapter 2 was to explore the causes of ovulation failures in these rabbit females. Results showed that non-ovulated females presented lower LH plasma concentration as well as higher body weight and leptin and BOHB 
plasma levels than ovulated females. Thus, ovulation failures in females from line $\mathrm{R}$ could be attributed to decreased LH plasma concentrations in these females which may be related with their higher body weight and leptin levels.

In the light of the previous results, the following three chapters were focused on improvement of the reproductive performance of these females through a different nutritional strategy: a feed-to-appetite diet of these females after the rearing period and prior to insemination. The initial hypothesis was that the females are submitted to a restricted nutritional regimen which is not enough to cope with their needs during reproduction, causing long-term disturbances of energy balance which leads to the subsequent reproductive problems.

Chapter 3 aimed to determine if a feed-to-appetite nutritional strategy would affect the hypothalamus-hypophysis axis and the quality of the produced oocytes, by transcriptomic analysis. While no differences were found in the microarray analysis of the hypothalamus-hypophysis, small differences were detected in the transcript expression analysis in oocytes of a group of genes selected. MSY2 was found to be downregulated in oocytes from restricted females. As a key regulator of maternal RNA transcription and translation, changes in this essential gene could explain some of the reproductive problems of these females with high growth potential.

Whether the differences found at oocyte level were inherent at embryonic level and so involved in the drop of fertility found in these females was studied in Chapter 4. Although no significant differences were revealed in ovulation, embryo recovery, and implantation rate, higher fetal and gestational losses were found in restricted females, as well as lower fetal growth. Thus, we concluded that the nutritional strategy employed may have an impact on the 
oocyte (Chapter 3), but we also demonstrated that these changes were inherited by the embryo, and result in disturbances in gestational losses and fetal growth.

For this reason, the final chapter of this thesis was conducted to determine whether these effects on reproductive and metabolic elements were also evident in females following the common semi-intensive farm production system. Although the results obtained showed small variances in NEFAs and $\mathrm{BOHB}$ plasma levels, and also in body weight, no differences were detected in global reproductive performance in terms of fertility, prolificacy and productivity.

The results obtained established that although differences are found at oocyte level and inherited by embryo and fetus, no improvements are reached with the proposed nutritional strategy in terms of reproductive performance when females selected for growth rate lead a normal semi-intensive production system. 

El objetivo general de esta tesis fue la caracterización en términos reproductivos de las hembras de una línea de conejo seleccionada por velocidad de crecimiento (Línea R) y el efecto de distintas estrategias nutricionales (ad libitum y restringidas previas al inicio de su vida reproductiva), con la finalidad de mejorar el rendimiento reproductivo de estas hembras.

En el capítulo 1 se evaluó y contrastó la influencia de los genotipos materno y embrionario en la supervivencia prenatal y crecimiento fetal en el transcurso de la gestación, entre las hembras de esta línea y una línea maternal. Por una parte, en lo referente a la supervivencia prenatal, el genotipo embrionario mostró ser un factor importante en los días 14 y 24 de gestación, mientras que a día 30 fue el genotipo materno el que resultó ser relevante. Por otra parte, en cuanto al peso fetal, solo se apreciaron diferencias el día 14 de gestación, siendo los fetos resultantes de la combinación del genotipo embrionario/materno de la línea maternal aquellos que mostraron un mayor peso $(0.29 \pm 0.01 \mathrm{~g}$ vs. $0.19 \pm 0.01 \mathrm{~g}$, para genotipos de la línea R). Sin embargo, mientras que ambos genotipos mostraron ejercer un efecto para el peso de la placenta fetal a día 24 de gestación, a día 30 el efecto de estos genotipos resultó determinante sobre el peso de la placenta materna. No obstante, a pesar de las diferencias encontradas, no se detectaron diferencias sobre la placenta fetal a nivel del transcriptoma ni en los niveles de progesterona e IGFI determinados en estas hembras. Por lo tanto, de este capítulo se puede concluir que en las hembras de líneas de conejo seleccionadas por velocidad de crecimiento, tanto el genotipo embrionario como el materno son factores clave en su rendimiento reproductivo. 
El objetivo del capítulo 2 fue explorar las causas de los fallos reproductivos en estas hembras de conejo. Los resultados mostraron que aquellas hembras que no ovularon presentaban menores niveles de LH, así como un mayor peso corporal y mayor concentración en sangre de leptinas y $\mathrm{BOHB}$ que las hembras que había ovulado. Por ello, los fallos en ovulación detectados en las hembras de la línea $\mathrm{R}$ podrían estar relacionados con una reducción en los niveles circulantes de LH, consecuencia del mayor peso de estas hembras y de los incrementados niveles de leptinas.

A la luz de estos resultados, los siguientes capítulos se enfocaron a la mejora del rendimiento reproductivo de estas hembras empleando una estrategia nutricional distinta: la ingesta libre y no controlada de alimento (ad libitum) de estas hembras tras el periodo de crianza hasta el momento del comienzo de su vida reproductiva. La hipótesis de partida fue que estas hembras son sometidas a un régimen nutricional restringido que no es suficiente para satisfacer sus necesidades energéticas durante la reproducción, lo que causa alteraciones en su balance energético que se manifestarían en los problemas reproductivos observados.

El capítulo 3 trató de determinar a través de un análisis trasncriptómico si la estrategia nutricional planteada afectaría el eje hipotalámico-hipofisario y la calidad de los ovocitos producidos. Mientras que no se encontraron diferencias en el análisis de un micrarray realizado sobre el hipotálamo-hipófisis de estas hembras, sí que se detectaron pequeñas diferencias en la expresión génica de los ovocitos. El transcrito MSY2 mostró una menor expresión en los ovocitos de las hembras restringidas. Este gen es un regulador clave en la maduración ovocitaria, ya que regula la transcripción y traducción de los ARN 
maternales. Por lo tanto, cambios en la expresión de este gen podrían explicar algunos de los problemas reproductivos de estas hembras.

En el capítulo 4 se estudió si estas diferencias detectadas a nivel ovocitario eran heredadas por el embrión pudiendo causar la baja fertilidad característica de estas hembras. Aunque no se encontraron diferencias en las tasas de ovulación, recuperación embrionaria y de implantación, sí que aparecieron diferencias significativas en las pérdidas fetales y gestacionales, así como un menor crecimiento fetal en los embriones procedentes de hembras con restricción alimentaria. Por ello, concluimos que la estrategia nutricional empleada tiene unas consecuencias en el ovocito (Capítulo 3), y demostramos que estos cambios parecen continuar en el embrión, resultando en alteraciones a nivel de pérdidas gestacionales y crecimiento fetal.

Por este motivo, el capítulo final de esta tesis fue desarrollado para evidenciar si los efectos reproductivos y metabólicos observados en los capítulos previos se manifestaban en las hembras que se encuentran en un sistema de producción tradicional en granja. Sin embargo, a pesar de que los resultados mostraron pequeñas variaciones en los niveles circulantes de NEFAs y BOHB y de peso corporal, no se encontraron diferencias en el rendimiento reproductivo global a nivel de fertilidad, prolificidad y productividad.

Con todo ello, los resultados obtenidos parecen indicar que a pesar de las diferencias encontradas a nivel ovocitario, embrionario y fetal, con el régimen nutricional propuesto no se logra alcanzar mejoras en la eficiencia reproductivo de las hembras seleccionadas por velocidad de crecimiento. 

L'objectiu general d'aquesta tesi va ser la caracterització en termes reproductius de les femelles d'una línia de conill seleccionada per velocitat de creixement (Línia R) i l'efecte de diferents estratègies nutricionals (ad libitum i restringides prèvies a l'inici de la seva vida reproductiva), amb la finalitat de millorar el rendiment reproductiu d'aquestes femelles.

En el capítol 1 s'avaluà i contrastà la influència dels genotipus matern i embrionari en la supervivència prenatal i el creixement fetal durant la gestació, entre les femelles d'aquesta línia i les de una altra línia maternal. D'una banda, pel que fa a I supervivència prenatal, el genotipus embrionari mostrà ser un factor important en els dies 14 i 24 de gestació, mentre que el 30 va ser el genotipus matern el que resultà rellevant. D'altra banda, pel que fa al pes fetal, només s'apreciaren diferències el dia 14 de gestació, moment en el qual el fetus resultants de la combinació de genotipus embrionari/matern de la línia maternal mostraren un major pes $(0.29 \pm 0.01 \mathrm{~g}$ vs. $0.19 \pm 0.01 \mathrm{~g}$, per als genotipus de la línia R). No obstant això, mentre que ambdós genotipus mostraren un efecte per al pes de la placenta fetal el dia 24 de gestació, el dia 30 este efecte resultà determinant en el pes de la placenta materna. Tot i això, no es detectaren diferències en la placenta fetal a nivell de trascriptoma ni en els nivells de progesterona i IGF-I determinats en aquestes femelles. Per tant, d'aquest capítol es pot concloure que en les femelles de conill seleccionades per velocitat de creixement tant el genotipus embrionari com el matern són factors clau en el seu rendiment reproductiu. 
L'objectiu del capítol 2 va ser explorar les causes de les fallades reproductives en aquestes femelles. Els resultats mostraren que aquelles femelles que no ovularen presentaren menor nivells de LH, així com un major pes corporal i major concentració en sang de leptines i BOHB que les femelles que sí que hi havia ovulat. Per això, les fallades d'ovulació detectades en les femelles de la línia $\mathrm{R}$ podrien estar relacionades amb la reducció en els nivells circulants de LH, com a conseqüència del major pes d'aquestes femelles i dels incrementats nivells de leptines.

A la llum d'aquests resultats, els capítols següents s'enfocaren a la millora del rendiment reproductiu d'aquestes femelles mitjançant una estratègia nutricional distinta: la lliure ingesta i no controlada d'aliment (ad libitum) d'aquestes femelles després del període de criança i fins al moment de l'inici de la vida reproductiva. La hipòtesi de partida fiu que aquestes femelles són sotmeses a un règim nutricional restringit que no és suficient per a satisfer es seves necessitats energètiques durant la reproducció, la qual cosa provoca alteracions en el balanç energètic que podrien manifestar-se en els problemes reproductius observats.

El capítol 3 tractà de determinar mitjançant un anàlisi trasncritòmic si la estratègia nutricional plantejada podria afectar l'eix hipotalàmic-hipofisiari i la qualitat dels ovòcits produïts. Metre que no es detectaren diferències en el anàlisi del microarray realitzat en el hipotàlem-hipòfisi d'aquestes femelles, sí que es detectaren petites diferències en l'expressió gènica del ovòcits. El transcrit MSY2 mostrà una menor expressió en els ovòcits de les femelles restringides. Aquest gen es un regulador clau en la maduració ovocitària, en tant en quant que regula la transcripció i la traducció dels ARN maternals. Per 
aquest motiu, canvis en l'expressió d'aquest gen podrien explicar alguns del problemes reproductius d'aquestes femelles.

En el capítol 4 s'estudià si aquestes diferències detectades a nivell ovocitari eren heretades per l'embrió i podrien causar la baixa fertilitat característica d'aquestes femelles. Encara que no se trobaren diferències en les taxes d'ovulació, recuperació embrionària i de implantació, sí que es trobaren diferències significatives en les pèrdues fetals i gestacionals, així com un menor creixement fetal en els embrions de les femelles provinents d'un règim alimentari restringit. Per això concloíem que l'estratègia nutricional emprada té conseqüències en el ovòcit (Capítol 3), i demostrarem que aquest canvis pareixen continuar en l'embrió, resultant en alteracions a nivell de pèrdues gestacionals i creixement fetal.

Per aquest motiu, el capítol final d'aquesta tesi fou desenvolupat amb la fi de evidenciar si els efectes reproductius i metabòlics observats en els capítols previs eren manifestats en les femelles que es troben en un sistema productiu tradicional de granja. No obstant això, tot i que el resultats mostraren petites variacions en els nivells circulants de NEFAs i BOHB i pes corporal, no es trobaren diferències en el rendiment reproductiu global, en termes de fertilitat, prolificitat i productivitat.

Amb tot això, els resultats obtinguts pareixen indicar que tot i que les diferències trobades a nivell ovocitari i embrionari amb un efecte significatiu en el desenvolupament i creixement fetal, amb el règim nutricional proposat no s'aconsegueix assolir millores en el rendiment reproductiu de les femelles seleccionades per velocitat de creixement sotmeses a una sistema tradicional de producció semi-intensiu. 

I. GENERAL INTRODUCTION 1

1. RABBIT SELECTION AND PRODUCTION 1

2. CHARACTERISTICS OF POPULATIONS SELECTED BY GROWTH RATE 3

2.1 Relationship between quantitative and reproductive traits in rabbits 4

2.2 Paternal lines

2.3 Effects of selection by growth rate on reproductive performance 11

3. NUTRITION 12

$\begin{array}{ll}3.1 \text { Energy deficit and reproductive performance } & 12\end{array}$

3.2 Interactions between reproduction and nutrition 13

$\begin{array}{ll}3.3 \text { Feeding strategies for improving reproduction } & 19\end{array}$

$\begin{array}{lr}\text { 4. LITERATURE CITED } & 20\end{array}$

$\begin{array}{ll}\text { II. OBJECTIVES } & 35\end{array}$

III.CHAPTER ONE. Role of embryonic and maternal genotype on prenatal survival and fetal growth in rabbit

$\begin{array}{ll}\text { ABSTRACT } & 39\end{array}$

$\begin{array}{ll}\text { INTRODUCTION } & 41\end{array}$

MATERIAL AND METHODS $\quad 42$

1. Ethical Statement 42

2. Animals 42

3. Embryo transfer 43

4. Prenatal survival rate and samples at Day 14,24 and 30

5. RNA Extraction $\quad 45$

6. Microarray analysis 46

7. RT-PCR 47

8. Progesterone and IGF I serum levels 48

9. Statistical analysis 50

RESULTS 51

1. Prenatal survival rate 51

2. Fetal and placental weight 53

3. Effect of group (R/R and $A / A)$ on fetal placental gene expression at Day 14 and

Day 24

4. Effect of maternal genotype on progesterone and IGF1 levels 57

$\begin{array}{ll}\text { DISCUSSION } & 58\end{array}$ 
IV.CHAPTER TWO. Study of ovulation failures in a rabbit line selected for gorwth rate

MATERIALS AND METHODS

1. Ethical Statement $\quad 72$

2. Animals 73

3. Determination of LH concentration and ovulation relationship 73

4. Hormone and metabolites analysis $\quad 74$

5. Body condition $\quad 76$

6. Statistical analysis 76

$\begin{array}{ll}\text { RESULTS } & 77\end{array}$

$\begin{array}{ll}\text { DISCUSSION } & 79\end{array}$

$\begin{array}{lc}\text { REFERENCES } & 82\end{array}$

V. CHAPTER THREE. Feed restriction regime in a rabbit line selected for growth rate alters oocyte maturation manifested by alteration in msy2 gene expression

$\begin{array}{ll}\text { ABSTRACT } & 91\end{array}$

$\begin{array}{ll}\text { INTRODUCTION } & 93\end{array}$

MATERIAL AND METHODS

1. Ethical Statement 94

2. Animals 95

3. Experiment 1. Hypothalamus-pituitary microarray 95

4. Experiment 2. Oocyte gene expression 98

$\begin{array}{lr}\text { 5. Statistical analysis } & 102\end{array}$

$\begin{array}{ll}\text { RESULTS } & 103\end{array}$

1. Experiment 1. Hypothalamus-pituitary microarray 103

$\begin{array}{ll}\text { 2. Experiment 2. Oocyte gene expression } & 104\end{array}$

$\begin{array}{ll}\text { DISCUSSION } & 105\end{array}$

$\begin{array}{ll}\text { REFERENCES } & 108\end{array}$ 
VI.CHAPTER FOUR. Effects of female dietary restriction in a rabbit growth line during rearing on reproductive performance and embryo quality

ABSTRACT

INTRODUCTION

MATERIAL AND METHODS

$\begin{array}{ll}\text { 1. Ethical Statement } & 119\end{array}$

2. Animals $\quad 119$

3. Experiment 1. Effect of feeding regimen on reproductive performance $\quad 120$

4. Experiment 2. Effect of feeding regimen on embryo development and fetal growth

5. Statistical analysis

$\begin{array}{ll}\text { RESULTS } & 127\end{array}$

1. Experiment 1. Effect of feeding regimen on reproductive performance $\quad 127$

2. Experiment 2. Effect of feeding regimen on embryo development and fetal growth

DISCUSSION

REFERENCES

VI. CHAPTER FIVE. Effects of rearin feeding programme on reproductive performance and metabolism on young rabbit does selected by growth rate

MATERIAL AND METHODS

1. Ethical Statement

2. Animals

3. Reproductive traits

4. Body condition

5. Collection of blood samples

6. Metabolites assay

7. Statistical analysis

$\begin{array}{lr}\text { 1. Reproductive performance } & 153\end{array}$

2. Body condition $\quad 155$

3. Blood metabolites parameters $\quad 157$ 
VIII. GENERAL DISCUSSION

IX. CONCLUSIONS 


\section{GENERAL INTRODUCTION}

Figure I.1: Schematic representation of the three-way cross used in rabbit production

Figure I.2: Components and factors affecting female reproductive performance

Figure I.3: Relations between nutrition and reproduction

\section{CHAPTER ONE}

Figure 1.1: Schematic illustration of the embryo transfer model used in this study 44 Figure 1.2: Prenatal survival at Day 14, 24 and 30 for the different lines Figure 1.3: Interaction of fetal survival at Day 24 when the covariate implantation rate is included

Figure 1.4: Fetal and placental (fetal and maternal) weights at Day 14, 24 and 30 of gestation

Figure 1.5: Interaction of fetal weight at Day 14

Figure 1.6: Interaction of fetal placenta weight at Day 24

Figure 1.7: Relative expression of vascular endothelial growth factor (VEGF), Epidermal Growth Factor receptor 3 (eRBB3), Transforming Growth Factor- $\beta 2$ (TGFB2), Insulin-like Growth Factor I (IGFI), Integrin alpha-I (ITGA I) and Interferon-gamma (IFNG) for validation of Day 14 fetal placentas microarray Figure 1.8: Relative expression of vascular endothelial growth factor (VEGF), Epidermal Growth Factor receptor 3 (eRBB3), Transforming Growth Factor- $\beta 2$ (TGFB2), Insulin-like Growth Factor I (IGFI), Integrin alpha-I (ITGA I) and Interferon-gamma (IFNG) for validation of Day 24 fetal placentas microarray Figure 1.9: Effect of maternal genotype on progesterone and IGFI serum levels at Day 14,21 and 28 of gestation

\section{CHAPTER TWO}

Figure 2.1: Mean LH concentration 90 minutes after natural mating or artificial insemination females, related to ovulation and gestation diagnosis

\section{CHAPTER THREE}

Figure 3.1: Relative expression of genes selected for validation of hypothalamus-hypophysis microarray. 


\section{CHAPTER FOUR}

Figure 4.1: Ultrasound measurements of the crown-up length (CRL) of fetus at different days of gestation

Figure 4.2: Schematic illustration of the experimental procedure used in experiment 2 to determine the effect of maternal feeding prior to mating on the embryo

Figure 4.3: Implantational, fetal and gestational losses for embryos derived from restricted and ad libitum fed females

Figure 4.4: Regression lines of fetal growth from day 14 to 28 of gestation in surrogate females for ad libitum and restricted produced embryos

\section{CHAPTER FIVE}

Figure 5.1: Litter size for ad libitum and restricted females

Figure 5.2: Live body weight evolution of females

Figure 5.3: Perirenal Fat Thickness evolution of females

Figure 5.4: Evolution of blood plasma (A) leptin, (B) non-esterified fatty acids (NEFA), (C) fructosamine and (D) beta-hydroxybutyrate concentrations in females 


\section{GENERAL INTRODUCTION}

Table I.1: Rabbit paternal lines most commonly used in rabbit production

\section{CHAPTER ONE}

Table 1.1: Primers sequence, accession number, amplicon size obtained, efficiency, correlation and reference where indicated, of genes analysed and housekeeping genes used

\section{CHAPTER TWO}

Table 2.1: Metablite concentration of naturally mated females if ovulated or non-ovulated after mating.

Table 2.2: Body conditions of naturally mated females if ovulated or nonovulated after mating.

\section{CHAPTER THREE}

Table 3.1: Primers sequence, accession number, amplicon size obtained, efficiency, correlation and reference where indicated, of genes analysed and housekeeping genes used for hypothalamus-hypophysis microarray validation

Table 3.2: Primers sequence, accession number, amplicon size obtained, efficiency, correlation and reference where indicated, of genes analysed and housekeeping genes used for oocyte gene expression analysis

\section{CHAPTER FOUR}

Table 4.1: Reproductive performance and body condition in ad libitum and restricted females after the rearing period

\section{CHAPTER FIVE}

Table 5.1: Effect of an ad libitum or restricted diet during rearing and Al success (pregnant status) on body condition. 



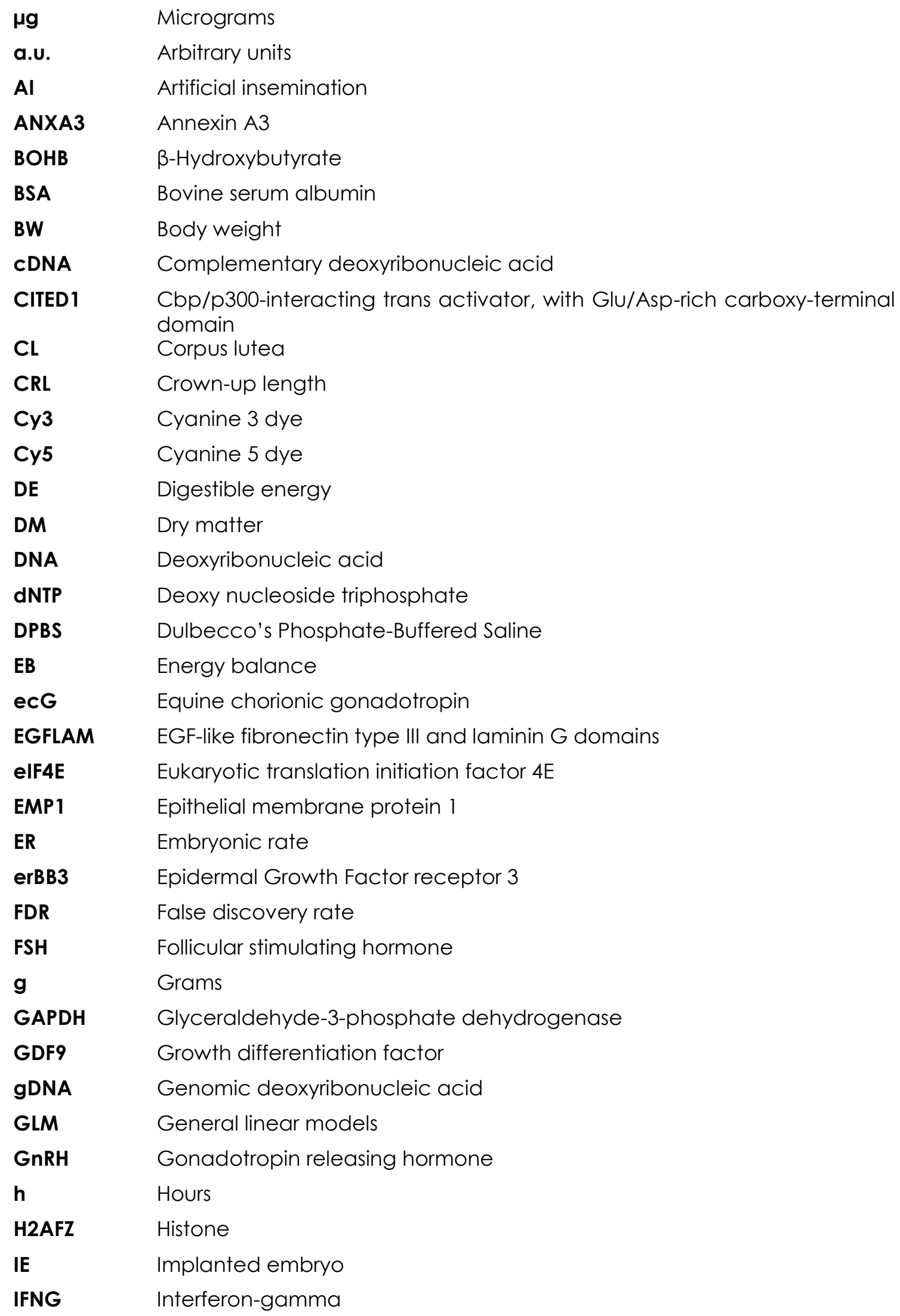




\begin{tabular}{|c|c|}
\hline IGF & Insulin-like growth factor \\
\hline IPTR & Inositol 1,4,5-triphosphate receptor \\
\hline ITGAI & Integrin alpha-I \\
\hline kg & Kilograms \\
\hline KR & Kindling rate \\
\hline LBW & Live bodyweight \\
\hline LH & Luteinizing hormone \\
\hline LRP2 & LDL-related protein \\
\hline LS & Litter size \\
\hline mg & Milligrams \\
\hline $\min$ & Minutes \\
\hline $\mathrm{mL}$ & Millilitres \\
\hline mRNA & Messenger ribonucleic acid \\
\hline MSY2 & Y-box binding protein 2 \\
\hline NADH & Nicotine adenine dinucleotide \\
\hline NEB & Negative energy balance \\
\hline NEFA & Non-esterified fatty acids \\
\hline ng & Nanograms \\
\hline $\mathrm{nM}$ & Nanomolar \\
\hline NM & Natural mating \\
\hline OR & Ovulation rate \\
\hline PAPOL & Poly(A) polymerase \\
\hline PARN & Poly(A)-specific ribonuclease \\
\hline PCR & Polymerase chain reaction \\
\hline PTF & Perirenal fat thickness \\
\hline RbLH & Rabbit luteinizing hormone \\
\hline RBP4 & Retinol-binding protein 4 \\
\hline RNA & Ribonucleic acid \\
\hline rpm & Revolutions per minute \\
\hline RT-PRC & Real time polymerase chain reaction \\
\hline s & Seconds \\
\hline SEM & Standard \\
\hline TB & Total born \\
\hline TGF- $\beta 2$ & Transforming Growth Factor- $\beta 2$ \\
\hline TNFAIP6 & Tumour necrosis factor alpha-induced protein 6 \\
\hline VEGF & Vascular endothelial growth factor \\
\hline vs & Versus \\
\hline wk & Weeks \\
\hline YY1 & Ubiquitously distributed transcription factor expression \\
\hline ZAR1 & Zygote arrest 1 \\
\hline
\end{tabular}




\title{
I. GENERAL INTRODUCTION
}

\author{
C. Naturil-Alfonso
}

Instituto de Ciencia y Tecnología Animal, Laboratorio de Biotecnología de la Reproducción, Universidad Politécnica de Valencia, Valencia, 46022 



\section{GENERAL INTRODUCTION}

\section{RABBIT SELECTION AND PRODUCTION}

Intensive rabbit meat production emerged in Europe at the end of the 1960s, but became consolidated in the 80s and 90s (Lebas et al., 1997). Currently, the European Union is the second-largest rabbit meat producer worldwide after China. Within the European countries, the principal rabbit meat producers sorted by production rates are Italy, Spain, France and Hungary (FAO-STAT, 2012).

The first breeding programme was consolidated in France in the 1960s (Legault et al., 1996). In Spain, the first breeding programmes began in the 1970s and continue to be developed today by two public institutions: Universidad Politécnica de Valencia (UPV, Valencia) and Institut de Recerca I Tecnologia Agroalimentàries (IRTA, Catalunya) (Baselga, 2004).

Efficiency of rabbit meat production depends on several traits, which can be divided into production and reproduction related traits (Baselga and Blasco, 1989; Baselga, 2004). Production traits (growth, feed efficiency, carcass and meat traits) are relevant during fattening period and attributed to paternal lines, while reproduction traits (kindling interval, number of weaning kits, number of live young rabbits and longevity) are important for maternal lines. To take advantage of both of these characteristics, in prolific species the three-way cross is the most commonly used system. Efficiency of rabbit meat production can be improved by taking advantage of the diversity of rabbit breeds and lines through crossbreeding. In a first cross, animals from two maternal lines selected for reproductive traits are mated to produce a crossbred female, 
which is used as stock doe for production on commercial farms. A second cross consists on mating the crossbred doe with males from a paternal line selected for growth rate at a given age (Figure 1.1). Afterwards, the second cross of a crossbred female with the terminal sire, combines the desirable traits (litter size and growth rate) into one composite breed which is kept as a pure bred (Bünger et al., 2005). The final aim of the cross is to capitalize on the complementarity between reproductive and growth traits to produce large number of rabbits with fast growth and high feed efficiency (Baselga, 2004). In this sense, the demand for crossbred does and the use of males from specialized paternal lines are becoming increasingly higher.

Additionally, in some cases, mainly in developing countries, where facilities allow selection on one line only, this line is selected for litter size and growth rate, and additionally for some traits related to maternal ability, such as litter weight at weaning (Bünger et al., 2005).

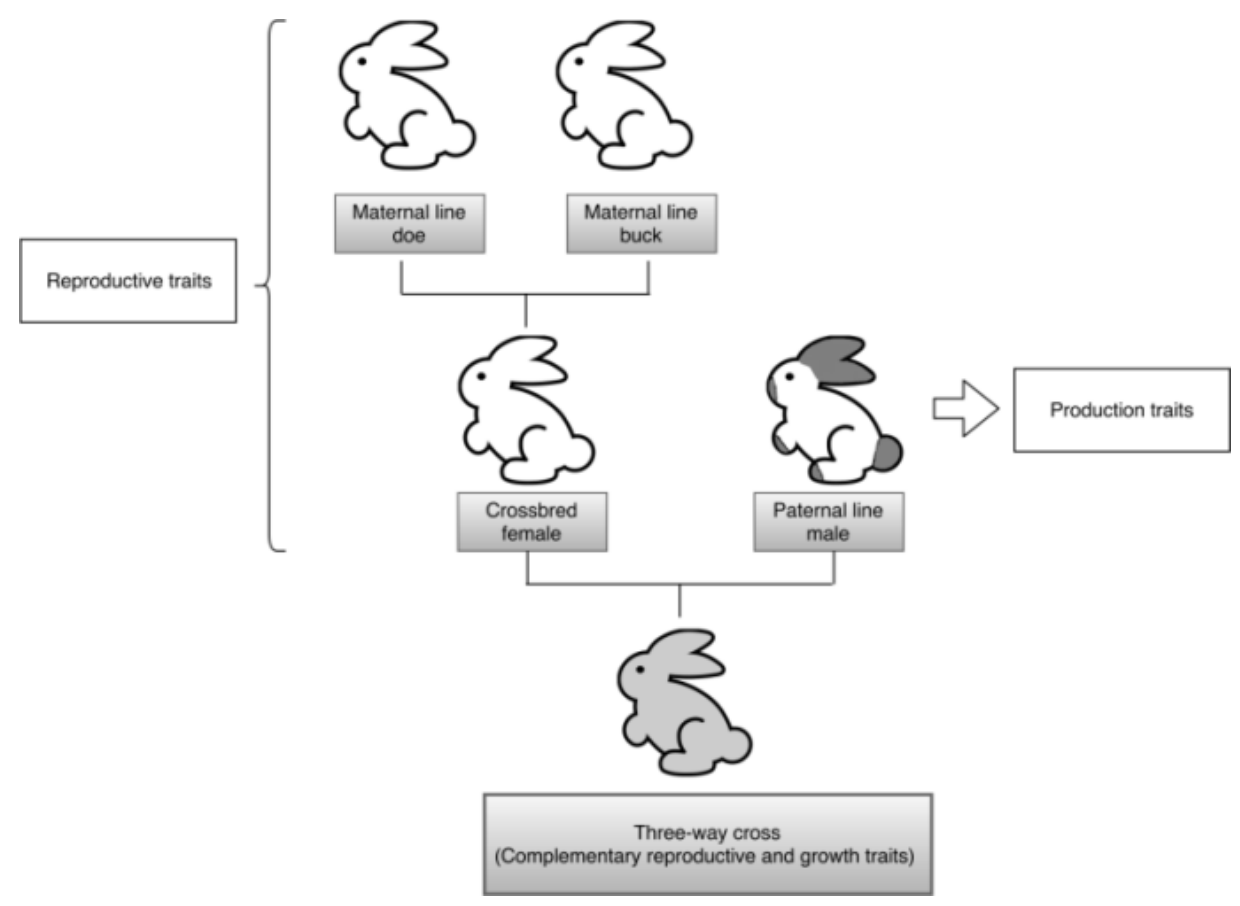

Figure I.1. Schematic representation of the three-way cross used in rabbit production. 


\section{CHARACTERISTICS OF POPULATIONS SELECTED BY GROWTH RATE}

Apart from the desired effects of genetic selection focused on high economic production efficiency, negative side effects become apparent when intensive selection for a single trait is performed. A population of animals that have been genetically selected for high production efficiency seem to be more at risk from behavioural, physiological (such as longevity and reproductive performance: fertility, litter size) and immunological problems (elevated disease incidence) (Rauw et al., 1998; Antonini and Cordiviola, 2010). Therefore, the relationships between quantitative and reproductive fitness traits in animals are of general biological importance and direct economic significance for breeding on animal farms.

A comparison between highly divergent strains/breeds/variants in several species (dogs, rabbits, sheep, pigs and mice) suggested a positive relationship between body weight (BW) or size and litter size (LS) and fecundity. A comparison between wild and selected populations in mice showed a reduction in size of the initially substantial positive genetic correlation between these traits in unselected populations with selection. One may assume that a positive correlation might also have originally existed in farm animals at the beginning of domestication. However, during domestication and through intense selection the correlation may also have been reduced. In fact, in breeds of farm animals that have undergone selection, there seems to be only a weak positive, zero or even negative genetic relationship between BW and LS. Thus, there are a number of deviations from this general pattern, indicating a substantial genetic plasticity allowing for the development of breed-/variant- 
specific reproductive strategies and relationships (reviewed by Bünger et al., 2005).

\subsection{Relationship between quantitative and reproductive traits in rabbits}

As both growth rate and litter size are relevant for rabbit production, the effects of growth selection on reproductive performance should be understood. In rabbit meat production, the efficiency and profitability of farms depend on reproductive success, defined by fertility and litter size (Piles et al., 2005). However, Rauw et al. (1998) showed that long-term selection for growth traits can result in physiological and/or reproductive problems, as well as an elevated disease incidence despite higher body condition scores (Sánchez et al., 2012).

To date, studies focused on genetic correlation between growth and reproductive characters in rabbit have provided dissimilar results. Several studies have shown that ovulation rate and litter size increase with the body weight of the doe in different breeds of rabbits ranging from 1.2 to $6 \mathrm{~kg}$ (Bünger et al., 2005), which suggests a positive relationship between BW and LS (Mgheni and Christensen, 1985; Camacho and Baselga, 1990). However, others found that the genetic correlation between average daily weight gain and reproductive traits in females is negative but low in magnitude: selection for growth traits could produce a small negative effect in fertility of paternal lines (Rochambeaua et al., 1989; Piles and Tusell, 2011). Other studies have established negative correlations between growth rate and sperm quality, but these differences were not determined in sperm production parameters (Lavara et al., 2008; 2011 ). 
Using different breeds and crossbreeds, early studies found that ovulation rate (OR) and LS increase with the BW of the doe (Gregory, 1932), which suggested a genetic correlation between BW and OR which may be mediated hormonally or genetically (Roberts, 1979; Brien, 1986). This was confirmed in rabbit by studies in the 1950s involving breeds with a wide range of BWs (from $1.2 \mathrm{~kg}$ to $6 \mathrm{~kg}$ ), which also suggested a positive relationship between BW and LS (reviewed by Bünger et al., 2005). However, certain breeds deviated substantially from this type of interbreed regression line and this relation can also break down during selection, allowing for relative independent development (reviewed by Bünger et al., 2005). Bolet et al. (2004) revealed that medium-weight breeds present higher LS than lighter and heavier breeds, with the lower LS in small-sized breeds when comparing medium-sized and smallsized breeds with a medium-sized control breed. Thus, no pattern appears when comparisons are made between breeds, as light and heavy breeds have smaller LS than some medium-weight breeds. Therefore, estimates of genetic correlation in rabbits between the litter size and growth traits are low and contradictory, and both positive and negative estimates have been reported, possibly depending on the line analysed (Camacho and Baselga, 1990). The magnitude and sign of the correlations could depend on the correlated reproductive trait, as well as the population or strain under study. Thus, genetic correlations between growth and reproductive traits in rabbits are contradictory, which may be due to the studied genetic line and the reproductive characteristics studied (Figure I.2) (Camacho and Baselga, 1990; Rochambeau et al., 1994; Gómez et al., 1998; Garreau et al., 2000; García and Baselga, 2002). 

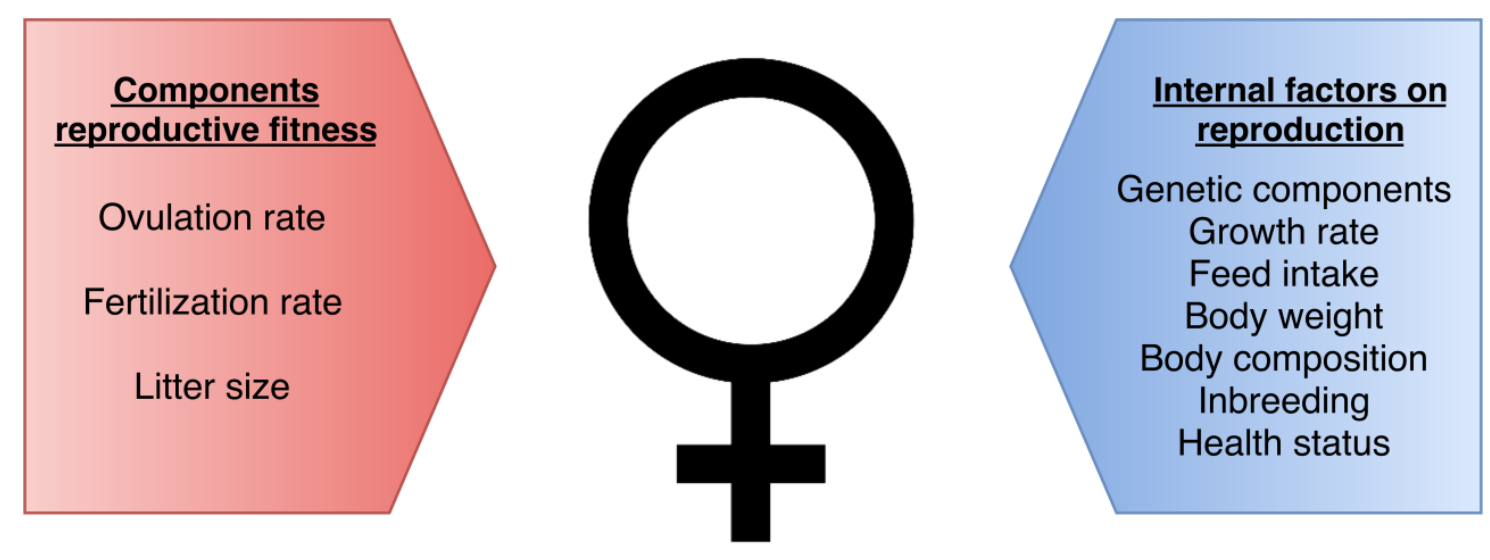

Figure 1.2. Components and factors affecting female reproductive performance.

\subsection{Paternal lines}

In this context, paternal lines are selected for traits that have an economic impact within a farm. These lines are commonly selected for post-weaning daily weight gain (Rochambreau et al., 1989; Estany et al., 1992) or for a certain weight at a time close to market (Lukefahr et al., 1996; Larzul et al., 2003), as essential features in farm production. De la Fuente and Rosell (2012) showed that paternal lines weighed $26 \%$ more than maternal and other lines/breeds not used in meat production, similar to the $23 \%$ showed by Bolet and Saleil (2002).

Selection for rapid growth rate was largely introduced to develop paternal lines in order to modify the growth pattern and feed efficiency, affecting carcass, tissue composition and meat quality traits (Pascual and Pla, 2007; Khalil and AlSaef, 2008). However, selection for growth traits has made the growing period shorter and the degree of maturity is thus lower at slaughter age (Pascual and Pla, 2007), which could in turn have a negative effect on carcass and meat. In 
practice, post-weaning growth is the criterion chosen to select paternal lines (Piles at al., 2004), although average weight daily gain is the trait most widely used for selection during the post-weaning period, which is moderately correlated with feed conversion ratio, which in turn is the desired trait in paternal lines (Khalil and Al-Saef, 2008).

Orengo et al. (2009) showed, on average, that genetic groups from lines selected for growth rate (Caldes and R) were heavier, with faster growth rate, higher feed intake and better feed conversion ratio than the genetic groups that originated from crosses among lines selected for litter size $(A, V$, and Prat as maternal lines). Nevertheless, parental lines are currently characterized by high feed intake, elevated growth rate and adult live weight (Estany et al., 1992), reduced reproductive performance (Mehaisen et al., 2004; Vicente et al., 2012) and by elevated disease incidence despite a higher body condition score (Sánchez et al., 2012). Some paternal rabbit lines are: 


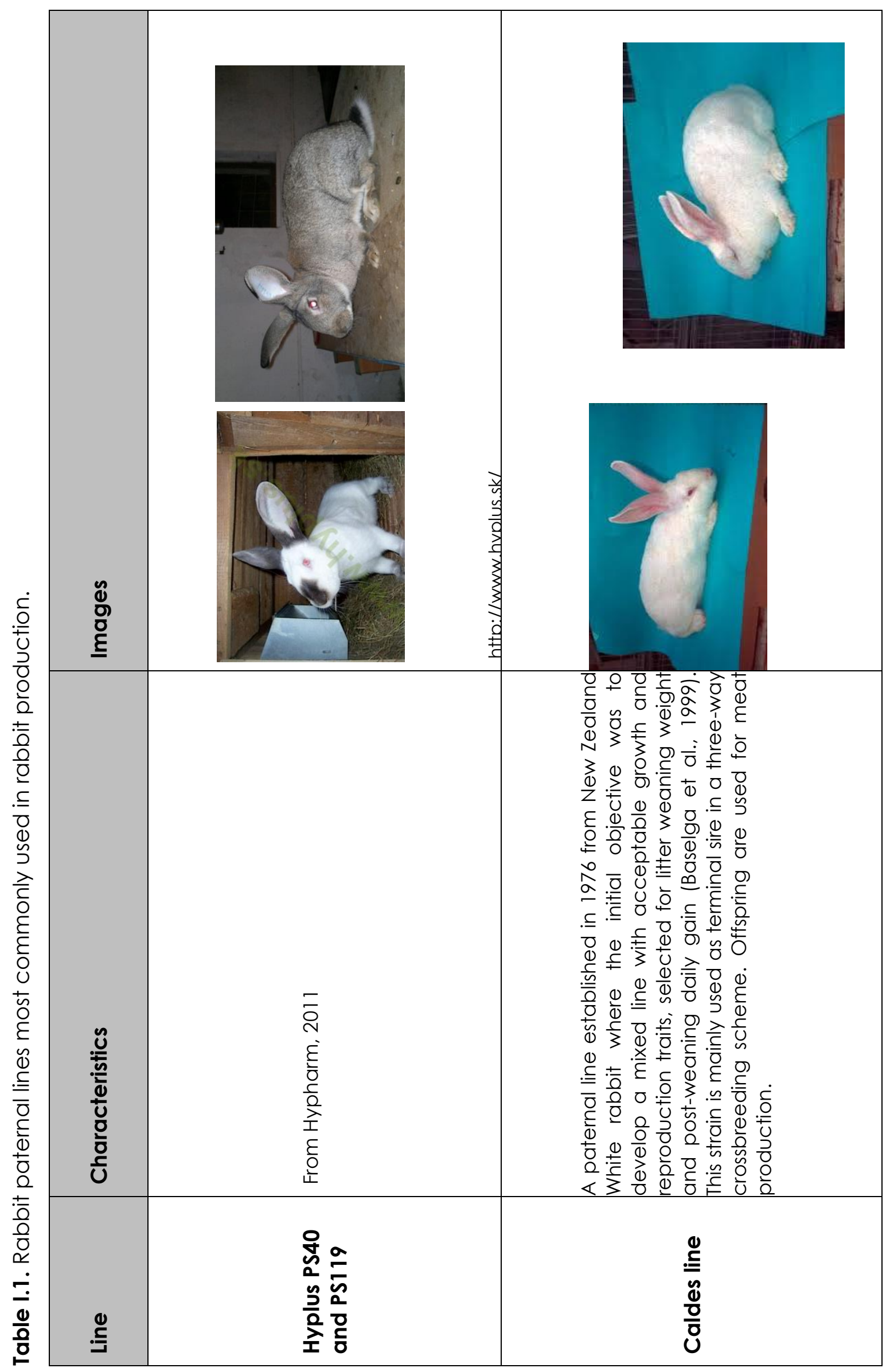




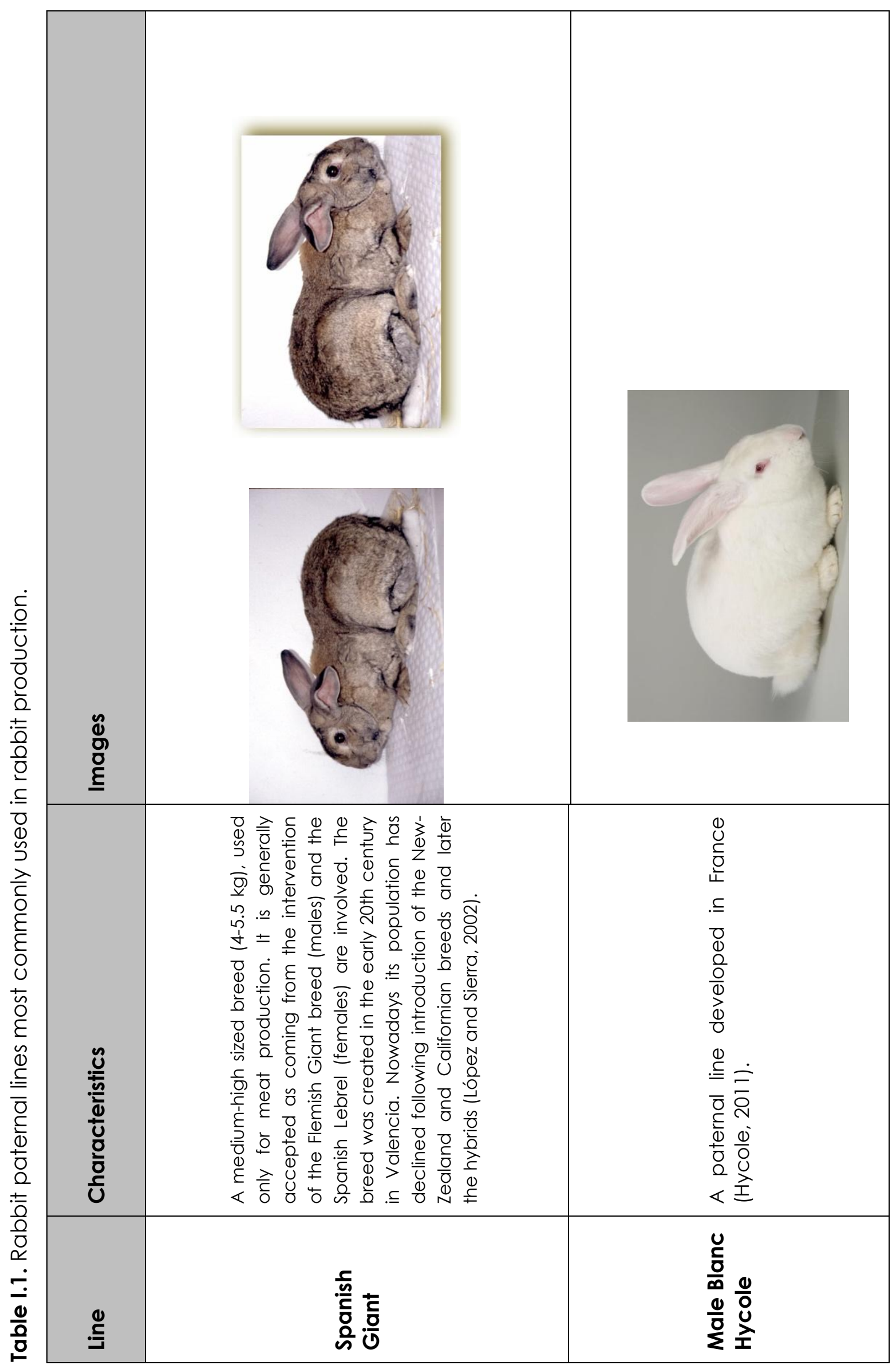




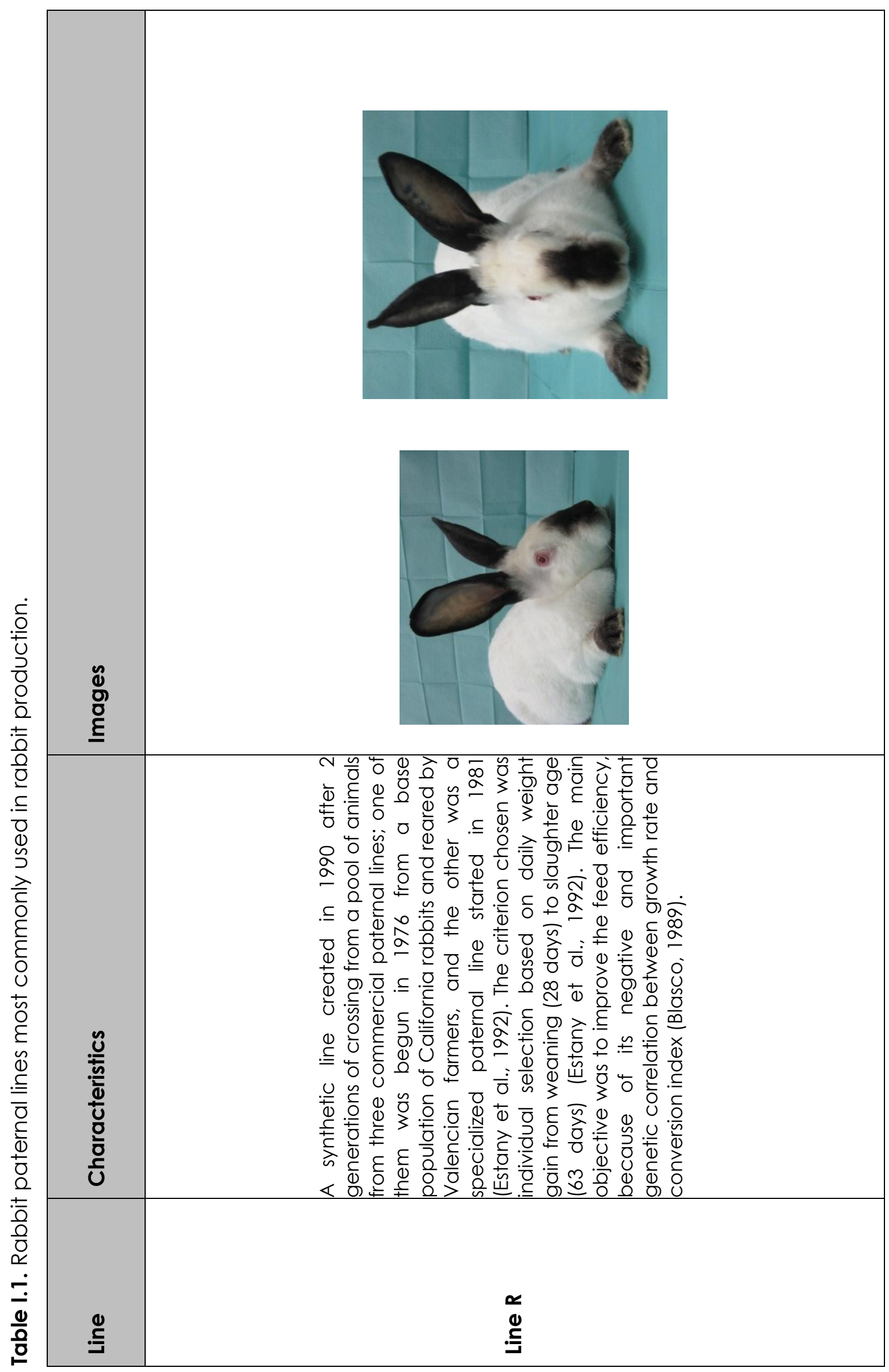




\subsection{Effects of selection by growth rate on reproductive performance}

There are several works in the literature relating reproductive characteristics in rabbit paternal lines (García and Baselga, 2002; Lavara et al., 2008; Tusell et al., 2012; Vicente et al., 2012). Specifically, paternal rabbit lines selected uniquely for growth rate are characterised by elevated growth rate and adult live weight (Estany et al., 1992), but reduced reproductive performance (Mehaisen et al., 2004; Vicente et al., 2012). In previous studies comparing paternal and maternal rabbit lines, differences have been reported in ovulation frequency, ovulation rate, prenatal survival, gestational losses and consequently in litter size (Vicente et al., 2003; 2012; 2013). Specifically, works carried out with line R, selected by weight daily gain, reported severe reproductive characteristics. This line showed more ovulation failures (30\%), higher implantational losses (20-30\%), gestational losses (50\%) and lower litter size than the maternal control line, despite similar ovulation rates and embryo development until day 6 of gestation (Llobat et al., 2012; Vicente et al., 2012). Additionally, these authors in rabbit and others (Ernst et al., 2000) in mice, showed that the embryo genotype of females selected for growth rate had a significant effect on embryo survival at implantation and fetal survival rate.

On the other hand, the selection process for the rabbit paternal line, showed a response per generation of $0.5 \mathrm{~g} /$ day in daily weight gain from weaning to slaughter and $118 \%$ overweight at end of fattening period, specifically $139 \%$ in adult females compared to the maternal line (Gómez et al., 1999). Reproductive troubles described in these rabbit parental lines have been reported in many mouse, rat and rabbit models of obesity (Tortoriello et al., 2004). Body fat excess has shown a negative effect on pulsatile LH release from 
the pituitary (Cano et al., 2008; Uenoyama et al., 2008), early embryonic gene expression (Picone et al., 2011), disturbances in pre-implantation development (Sjoblom et al., 2005), reduction in implantation and fetal development (Haggarty, 2002) and reduced birth weights of the kits (Montoudis et al., 1999; Cordier et al., 2013).

\section{NUTRITION}

Apart from intrinsic factors of the animal, such as genotype, other factors are able to modify the animal's reproductive performance. Among these factors, the most important are those which affect the energy balance of the female, such as feeding, reproductive rhythm and stress (Fortun-Lamothe, 2006).

\subsection{Energy deficit and reproductive performance}

The reproductive performance of animals could be greatly affected when their nutritional balance is negative. In this sense, the reproductive rhythm currently applied in rabbit production means that does are inseminated while suckling, so gestation and lactation overlap, which in turns has an adverse effect on reproductive performance, such as fertility and litter size (Maertens and Okerman, 1988; Cervera et al., 1993). Energy balance (EB) of animals is influenced by both intrinsic factors (parity, LS, genetic type...) and extrinsic factors linked to the rearing conditions (reproductive rhythm, environmental temperature...) (Fortun-Lamothe, 2006). Data indicate that EB during the reproductive cycle explains many of the reduced performance issues in rabbit does. Specifically, NEB seems to have an effect on the fall in ovulation due to an abnormal follicular development, on the quality of the oocytes and 
gametes produced, fecundity, embryo development at early stages, the quality of uterine environment and secretion of prostaglandins (Butler and Smith, 1989; Foxcroft et al., 2006; Fortun-Lamothe, 2006).

In this way, body condition at first insemination influences reproductive performance. Particularly, the state of the body reserves (the quantity of adipose tissue) affects the ability to reproduce in many animal models (Pasquali and Casimirri, 1993; Tortoriello et al., 2004). Adipose tissue reserves can influence the reproductive ability of the females in two ways: 1) the time of first ovulation and 2) the ability to maintain reproductive function during adulthood (Cunningham et al., 1999). In rabbit, does with optimum body condition reach higher fertility rates (Rommers et al., 2004; Castellini et al., 2006; Feugier and Fortun-Lamothe, 2006). This body condition can be influenced by feed intake during rearing and before mating/artificial insemination (Rommers et al., 2004). Moreover, maternal body weight or body condition before or immediately after conception may play a role in feto-placental growth in early pregnancy, altering the weight of the fetal membranes and individual fetal weight (MacLaughlin et al., 2005).

\subsection{Interactions between reproduction and nutrition}

The interactions between nutrition and reproduction are established through endocrine signals that transmit the nutritional status of the female to the hypothalamus-pituitary axis (Foster et al., 1998). The correlation between body status and/or nutritional state and reproduction is controlled by several factors. These metabolites and hormones, which are likely to be mediators between nutritional status and reproductive performance, are implicated in different key 
points of the mammalian reproductive axis, including glucose, NEFA, leptin, insulin and IGF-I (Ferguson et al., 2003; Brecchia et al., 2006). Previous studies have demonstrated that the nutritional regimen before and after mating influences the profile of circulating concentrations of these metabolic and reproductive hormones (Ferguson et al., 2003; Brecchia et al., 2006; GarcíaGarcía et al., 2011).

\subsubsection{Leptins}

In particular, leptin, a hormone synthesized by the adipose tissue, is correlated with the body lipids and modulates fat reserves and reproductive function (Cardinali et al., 2008). In fact, leptin has been established as the main signal telling the brain that energy stores are sufficient to support the energy demands of reproduction, and is a major determinant factor in the timing of puberty (Ahima et al., 1997). Additionally, leptin has a dual effect on the reproductive mechanisms: the fall in leptin levels, associated with insufficient body reserves to trigger gestation or lactation, with the consequent reproductive function inhibition (Fortun-Lamothe, 2006). At the same time, leptin above a certain threshold impairs ovarian steroidogenesis and has deleterious effects on reproduction (Zerani et al., 2004). Specifically, leptin controls GnRH functionally through its ability to activate kisspeptin-positive neurons (Smith et al., 2006). Kisspeptin has been shown to stimulate GnRH neurons in several species (Martin et al., 2008) which finally affects the reproductive capacity in animals by disturbing $\mathrm{LH}$ and FSH secretion and hence estradiol and testosterone release. 
Leptin mRNA has been found in the hypothalamus-anterior-pituitary in pigs (Barb, 1999) which indicates that leptin plays a role as a central sign to the brain and/or pituitary gland, regulating $\mathrm{LH}$ and to a lesser extent, FSH release (Moschas et al., 2002). On the other hand, the findings of leptin receptors in the different ovarian structures and the oviducts of rabbits suggest that leptin may have a role in the steroidogenesis of pre- and post-implantatory follicles, as well as in early developmental stages of blastocysts (Zerani et al., 2004; 2005). In fact, Ferguson et al. (2003) found a positive correlation between leptin plasma concentrations and oocytes in metaphase II.

\subsubsection{Insulin and related growth factors}

Several works have suggested a key role of insulin and insulin-like growth factors (IGFs) at hypothalamus-hypophysis level and at ovarian level by modifying endocrine, paracrine and autocrine regulation, which permit follicle growth ovulation and functioning of the corpus luteum (Fortun-Lamothe, 2006).

The main physiological role of insulin is glucose homeostasis, the regulation of nutrient substrate metabolism (Gamba and Pralong, 2006). However, insulin has also been shown to play a modulatory role in the hypothalamus-hypophysisgonad axis. Conditions of low or null insulin levels are associated with suppressed gonadotropins and reproductive deficiencies (Pralong, 2010), but mice lacking insulin receptors also had impaired gonadal function associated with GnRH deficiency (Bruning et al., 2000). Specifically, insulin exerts an effect on GnRH neurons modulation both directly and indirectly, through inhibiting the 
hypothalamic arcuate nucleus Neuropeptide Y expression, which inhibits GnRH expression and secretion per se (Pralong, 2010).

Additionally, insulin and insulin-like growth factors (IGF-I and IGF-II) play a relevant role in embryonic and fetal development. IGFs play an essential role in early embryo development, growth and differentiation, but also in the implantation process (Thieme et al., 2012). At early embryo development they mediate mitogenic, anti-apoptotic and anabolic effects in mammalian preimplantation embryos (Navarret-Santos et al., 2004).

\subsubsection{Glucose and fructosamine}

Glucose has been widely employed in experiments which try to relate nutrition and reproduction, as a good indicator of EB in animals (Fortun-Lamothe, 2006). Adequate levels of plasma glucose concentrations are necessary for proper functioning and preparation of the ovary, oviducts and uterus (Oikonomou et al., 2008; Wathes et al., 2011; Green et al., 2012). The higher concentration of glucose in blood may prepare the uterus for inception and maintenance of a pregnancy later post-partum (Wathes et al., 2011). In the rabbit, a fall in glycaemia has been observed during the course of gestation in response to the gradual increase in the requirements for fetal growth (Gilbert et al., 1984; ParigiBini, 1988). Plasma glucose levels reach a minimum in rabbits which are simultaneously gestating and lactating (Fortun, 1994).

Fructosamine is a product of non-enzymatic glycation. It is measured as an indicator of glucose levels, being a more stable indicator of short-term glycaemic status. The serum concentration of fructosamine correlates with the 
plasma glucose level, reflecting the average blood glucose levels for the previous 10-14 days (True, 2009).

\subsubsection{Non Esterified Fatty Acids (NEFA)}

Free fatty acids are released by the action of hormone-sensitive lipase on triglyceride stores in adipose tissue and an increase in NEFA concentrations generally indicates mobilization of body lipids and a negative energy balance (Emery et al., 1992). Thus, the amount of plasma NEFAs concentration is used as an indicator of body reserve mobilization and energy balance by the females (Fortun-Lamothe, 2006). Consequently, circulating levels of NEFAs are higher in rabbits gestating and lactating, at the start and in the middle of lactation. At the end of lactation these levels no longer increase, reflecting the relative exhaustion of fat reserves of the lactating females at this stage (FortunLamothe, 2006). Fortun-Lamothe and Prunier (1999) showed that NEFA concentrations were higher (by $41.7 \%$ ) in the females which refuse to mate than in those which allowed mating, but also in non-ovulating females than others $(0.223 \mathrm{mmol} / \mathrm{L}$ vs. $0.19 \mathrm{mmol} / \mathrm{L})$. Moreover, elevated NEFAs levels in cow have been associated with a pro-apoptotic effect on granulosa cells and diminished oocyte quality, with consequent reduction in fertilization, cleavage and embryonic development (Jorritsma et al., 2004; Leroy et al., 2005; Vanholder et al., 2005).

\subsection{5 $\beta$-Hydroxybutyrate (BOHB)}

$\mathrm{BOHB}$ is a ketone product of breakdown of fatty acids. When the body has insufficient carbohydrates available to cope with energy demands, it begins to utilize stored fat reserves for energy production. BOHB is one of the compounds 
released by the breakdown of fats in the body. Elevated concentrations of BOHB in dairy cows have been associated with reduced post-partum reproductive performance (Opsina et al., 2010). In fact, this metabolite and NEFAs are employed as an indicator of fat oxidation and mobilization (respectively) which in turns reflect the success of an animal's adaptation to an NEB situation (Herdt, 2000).

Figure I.3 schematics of the relationship between nutrition and reproduction.

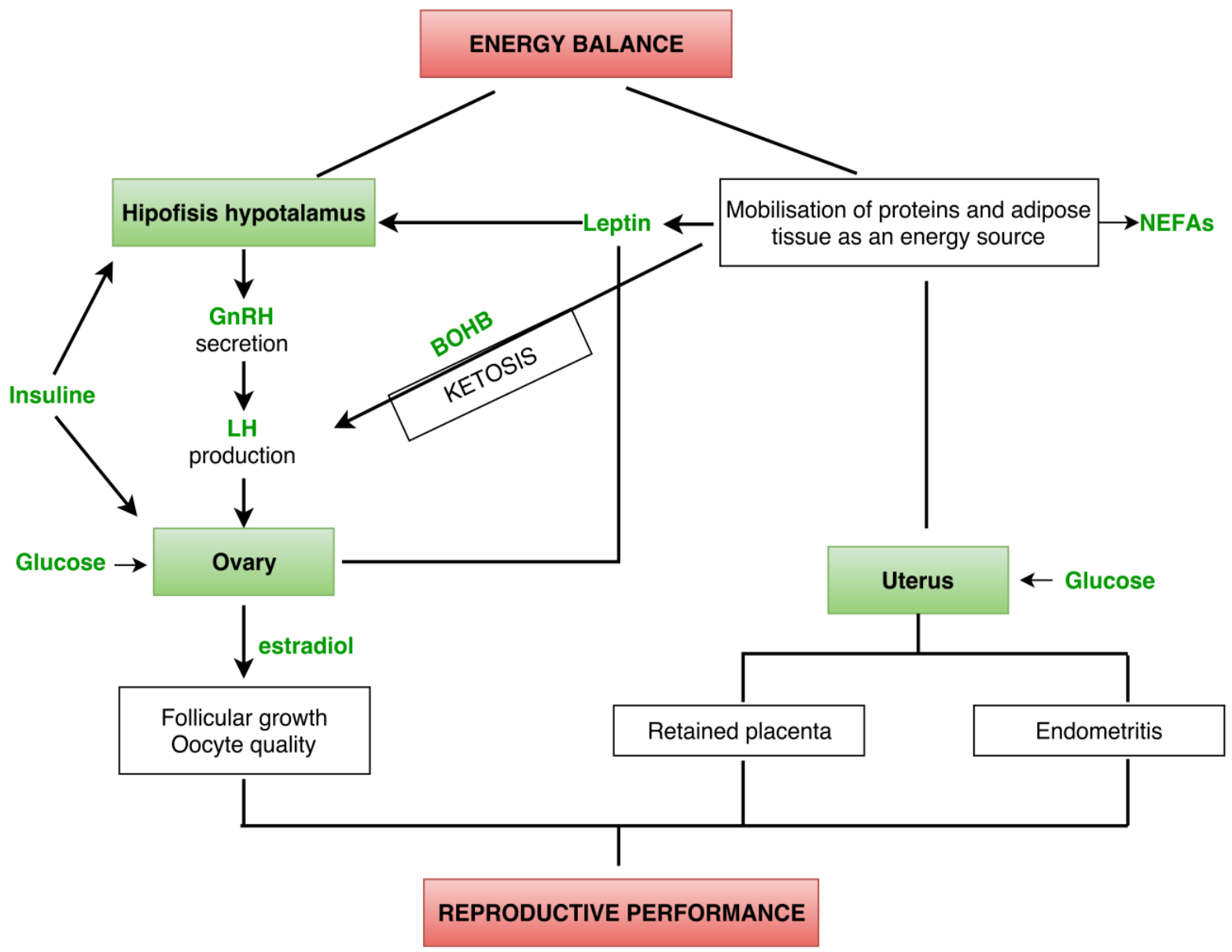

Figure I.3. Relations between nutrition and reproduction. 


\subsection{Feeding strategies for improving reproduction}

Several strategies are being proposed for better management of the energy balance in females to improve their performance or body condition (FortunLamothe, 2006). Feeding regimen has been linked to oocyte quality and embryo and fetal development (Wolfenson and Blum, 1988). In recent years, much work has been done on the influence of an increase in the energy content of the feed on body conditions and/or reproductive performance in rabbits (reviewed by Pascual et al., 2003). Although nutritional regimes after mating can have an effect, more data indicate that modifications to the nutritional regimen before mating may have greater impact on embryo survival and uniformity of litter size than the diet after mating (Ashworth et al., 1999a, b). Several reports have established that an altered nutritional regimen prior to mating can influence follicular/oocyte characteristics, but also that the maternal diet during pre-implantation development acts as a signalling input to the early embryo to regulate its future growth, as the peri-implantation period is a key period for future embryo development (Edwards and McMillen, 2002; MacLaughlin et al., 2005; Watkins et al., 2008; Picone et al., 201 1; Daoud et al., 2012, Lorenzo et al., 2014).

In this sense, two feeding regimes (restricted or ad libitum) have mainly been tested. A restrictive diet during rearing is used to control body condition and prevent overfattening, while an ad libitum diet provides better sexual development in terms of receptivity, number of corpora lutea and recovery rate, even containing more fat (Rommers et al., 2004). An ad libitum diet has also been shown to increase ovulation rates, embryo survival at implantation and blastocyst size (Ashworth et al., 1999a, b). Nutritionally-derived factors can 
result in unbalanced energy reserves, endocrine support of gestation and uterine blood flow (Brecchia et al., 2005, Cappon et al., 2005; Fortun-Lamothe, 2006).

Additionally, other nutritional strategies have been carried out, such as modification of dietary components with fibre-rich diets, high-fat diets, highstarch diets, or even supplements such as propylene glycol or omega-3 fatty acids in order to improve reproductive performance of rabbit females (Lorenzo et al., 2014).

\section{LITERATURE CITED}

Ahima RS, Dushay J, Flier SN, Prabakaran B, Flier JS. 1997. Leptin accelerates the onset of puberty in normal female mice. J Clin Invest 99 391-395.

Asworth CJ, Antipatis C, Beattie L. 1999a. Effects of pre- and post-mating nutritional status on hepatic function, progesterone concentration, uterine protein secretion and embryo survival in Meishan pigs. Reprod Fertil Devel 11 6773.

Asworth CJ, Beattie L, Antipatis C, Vallet J. 1999b. Effects of pre- and postmating feed intake on blastocyst size, secretory function and glucose metabolism in Meishan gilts. Reprod Fertil Devel 11 323-327.

Antonini AG, Cordiviola C. 2010. Mejoramiento genético en conejos para carne (Oryctolagus cuniculus). BAG, J Basic Appl Genet 21 art 5.

Barb CR. 1999. Role of leptin modulating neuroendocrine function: a metabolic link between brain-pituitary and adipose tissue. Reprod Dom Anim $34111-125$.

Baselga M, Blasco A. 1989. Mejora genetica del conejo de produccion de carne. Ed Mundi-Prensa Libros SA, Madrid. 
Baselga M, García ML, Gómez EA, Rafel O, Ramón J. Selection, diffusion and performances of six Spanish lines of meat rabbit. In: Testik A. (ed.), Baselga M. (ed.) 2. International Conference on Rabbit Production in Hot Climates. Zaragoza: CIHEAM, 1999. P. 147-152 (Cahiers Options Méditerranéennes; n.41).

Baselga M. 2004. Genetic improvement of meat rabbits. Programmes and diffusion. In: Proc. 8th World Rabbit Congress, Puebla, Mexico, 1-13.

Blasco A. 1989. Genética y nutrición del conejo. In C. de Blas Alimentación del conejo. Ediciones Mundi,Prensa, Madrid.

Bolet G, Saleil G. 2002. Strain INRA1077 (France). En: Khalil M.H., Baselga M. (Eds.) Rabbit genetic resources in Mediterranean countries. CIHEAM. Zaragoza, España, pp. 109-116.

Bolet G, Brun JM, Lechevestrier S, Lopez M, Boucher S. 2004. Evaluation of the reproductive performance of eight rabbit breeds on experimental farms. Anim Res 53 59-65.

Brecchia G, Bonanno A, Galeati G, Federici C, Maranesi M, Gobbetti A, Zerani M, Boiti C. 2006. Hormonal and metabolic adaptation to fasting: Effects on the hypothalamic-pituitary-ovarian axis and reproductive performance of rabbit does. Domest Anim Endocrinol 31 105-122.

Brien FD. 1986. A review of the genetic and physiological relationships between growth and reproduction in mammals. Anim Breed Abstr 54 975-997.

Bruning JC, Gautman D, Burks DJ, Gillette J, Schubert M, Orban PC, Rudiger K, Kroneb W, Muller-Wieland D,Kahn CR. 2000. Role of brain insulin receptor in control of body weight and reproduction. Science 289 2122-2125.

Bunger L, Lewis RM, Rothschild MF, Blasco A, Renne U, Simm G. 2005. Relationships between quantitative and reproductive fitness traits in animals. Phil Trans R Soc B 360 1489-1502.

Butler WR, Smith RD. 1989. Interrelationship between energy balance and post partum reproductive function in dairy cattle. J Dairy Sci 72 767-783. 
Camacho J, Baselga M. 1990. Genetic correlation between reproductive and growth traits in rabbits. In Proc: 4th World Congress on Genetics Applied to the Livestock Production, Edinburgh, Scotland 16:366-369.

Cano P, Jiménez-Ortega V, Larrad A, Reyes Tosco CF, Cardinali DP, Esquifina Al. 2008. Effect of a high-fat diet on 24-h pattern of circulating levels of prolactin, luteinising hormone, testosterone, corticosterone, thyroid-stimulating hormone and glucose, and pineal melatonin content, in rats. Endocrine 33118 125.

Cappon GD, Fleeman TL, Chapin RE, Hurtt ME. 2005. Effects of feed restriction during organogenesis on embryo-fetal development in rabbit. Birth Defects Research 74, 424-430.

Cardinali R, Dal Bosco A, Bonanno A, Di Grigoli A, Rebollar PG, Lorenzo PL, Castellini C. 2008. Connection between body condition score, chemical characteristics of body and reproductive traits of rabbit does. Livest Sci 116 209215.

Castellini C, Dal Bosco A, Cardinali R. 2006. Long term effects of postweaning rhythm on the body fat and performance of rabbit doe. Reprod Nutr Dev 46 195-204.

Cervera C, Fernandez-Carmona J, Viudes P, Blas E. 1993. Effect of remating interval and diet on the performance of female rabbits and their litters. An Prod 56 399-405.

Cordier AG, Léveille P, Dupont C, Tarrade A, Picone O, Larcher T, Dahirel M, Poumerol E, Mandon-Pepin B, Lévy R, Chavatte-Palmer P. 2013. Dietary lipid and cholesterol induce ovarian dysfunction and abnormal $\mathrm{LH}$ response to stimulation in rabbits. Plos one 8 e63101.

Cunningham MJ, Cliftoon DK, Steiner RA. 1999. Leptin's actions on the reproductive axis: perspectives and mechanisms. Biol Reprod 60 216-222. 
Daoud NM, Mahrous KF, Ezzo OH. 2012. Feed restriction as a biostimulant of the production of oocytes, their quality and GDF-9 gene expression in rabbit oocytes. Anim Reprod Sci 136 121-127.

De la Fuente LF and Rosell JM. 2012. Body weight and body condition of breeding rabbits in commercial units. J Anim Sci 90 3252-3258.

De Rochambeau H, Bolet G, Tudela F. 1994. Long term selection. Comparison of two rabbit strains. In: Proc. $5^{\text {th }}$ World Congress on Genetics Applied to Livestock Production, Guelph 19, 257-260.

Edwards LJ, McMillen IC. 2002. Impact of maternal undernutrition during the periconceptional period, fetal number, and fetal sex on the development of the hypothalamo-pituitary adrenal axis in sheep during late gestation. Biol Reprod 66 1562-1569.

Emery RS, Liesman JS, Herdt TH. 1992. Metabolism of long chain fatty acids in ruminant liver. Anim Nutr Phys 122 832-837.

Ernst CA, Rhees BK, Miao CH, Atchely WR. 2000. Effect of long-term selection for early postnatal growth rate on survival and prenatal development of transferred mouse embryos. J Reprod Fert 118 205-210.

Estany J, Camacho J, Baselga M, Blasco A. 1992. Selection response of growth rate in rabbits for meat production. Genet Sel Evol 24 527-537.

FAO, STAT. 2012. Statistics Data: Food and Agriculture organization http://faostat.fao.org/faostat/servlet/xteservlet3? areas=\%3e862\&items $=1141$ \&el ements $=51 \&$ year $=2003 \&$ xaxis=years $\&$ xaxis $=$ countries $\&$ aggreate=over_areas $\&$ ca Iculate=mean+std_dev\&domain=sua\&itemtypes=production.livestock.primary\& language $=e n$.

Ferguson EM, Ashworth CJ, Edwards SA, Hawkins N, Hepburn N, Hunter MG. 2003. Effect of different nutritional regimens before ovulation on plama concentrations of metabolic and reproductive hormones and oocyte maturation in gilts. Reproduction 126 61-71. 
Feugier A and Fortun-Lamothe L. 2006. Extensive reproductive rhythm and early weaning improve body condition and fertility of rabbit does. Anim Res $\mathbf{5 5}$ 459-470.

Fortun-Lamothe L. 1994. Influence of progesterone supplementation on foetal survival in concurrently pregnant and lactating rabbit does. Reprod Nutr Dev 34 125-131

Fortun-Lamothe L. 2006. Energy balance and reproductive performance in rabbit does. Anim Repr Sci 93 1-15.

Fortun-Lamothe L, Prunier A. 1999. Effects of lactation, energetic deficit and remating interval on reproductive performance of primimarous rabbit does. Anim Reprod Sci 55 289-298.

Foster DL, Nagatani S, Bucholtz DC, Tsukamura H, Tanaka T, Maeda K, Donna HR. 1998. Metabolic links between nutrition and reproduction: signals, sensors, and pathways controlling GNRH secretion. In Nutrition and reproduction. (pp. 59-80). Lovisiana State University Press.

Foxcroft GR, Dixon WT, Novak S, Putman CT, Town SC, Vinsky MDA. 2006. The biological basis for prenatal programming of postnatal performance in pigs. J Anim Sci 84 105-112.

Gamba M and Pralong FP. 2006. Control of GnRH neuronal activity by metabolic factors: The role of leptin and insulin. Mol Cell Endocrinol 254 133-139.

García ML, Baselga M. 2002. Estimation of correlated response on growth traits to selection in litter size of rabbits using a cryopreserved control population and genetic trends. Livest Prod Sci 78 91-98.

García-García RM, Rebollar PG, Arias-Álvarez M, Sakr OG, BermejoÁlvarez P, Brecchia G, Gutierrez-Adan A, Zerani M, Boiti C, Lorenzo PL. 2011. Acute fasting before conception affects metabolic and endocrine status without impacting follicle and oocyte development and embryo gene expression in the rabbit. Reprod Fertil Dev 23 759-768. 
Garreau H, Szendro ZS, Larzul C, Rochambeau De H. 2000. Geentics parameters and genetic trends of growth and litter sizr in the White Phannon Breed. In: Proc. $7^{\text {th }}$ World Rabbit Congress, Valencia, Spain, 403-408.

Gilbert M, Hay WW, Johnson RL, Battaglia FC. 1984. Some aspects of maternal metabolism throughout pregnancy in the conscious rabbit. Pediatr Res 18 854-859.

Giudice LC, Mark SP, Irwin JC. 1998. Paracrine actions of insulin-like growth factors and IGF binding protein-1 in non-pregnant human endometrium and at the decidual-trophoblast interface. J Reprod Immunol 39 133-148.

Gomez EA, Baselga M, Rafel O, Garcia ML, Ramon J. 1999. Selection, diffusion and performances of six Spanish lines of meat rabbit. Cahiers Options Mediterraneennes 41 147-152.

Gómez EA, Rafel O, Ramon J. 1998. Genetic relationships between growth and litter size traits at first parity in a specialized dam line. In: Proc. $6^{\text {th }}$ World Congress on Genetics Applied to Livestock Production, Armidale 25, 552-555.

Green JC, Meyer JP, Williams AM, Newsom EM, Keisler DH, Lucy MC. 2012. Pregnancy development from day 28 to 42 of gestation in postpartum Holstein cows that were either milked (lactating) or not milked (not lactating) after calving. Reproduction 143 699-711.

Gregory, PW. 1932. The potential and actual fecundity of some breeds in rabbits. J Exp Zool 62 271-285.

Haggarty P. 2002. Placental regulation of fatty acid delivery and its effect on fetal growth- a review. Placenta 23 S28-38.

Herdt TH. 2000. Ruminant Adaptation to Negative Energy Balance: Influences on the Etiology of Ketosis and Fatty Liver. Vet Clin N Am-Food A 16 215-230.

Jorritsma R, César ML, Hermans JT, Kruitwagen CL, Vos PL, Kruip TA. 2004. Effects of non-esterified fatty acids on bovine granulosa cells and developmental potential of oocytes in vitro. Anim Reprod Sci 81 225-235. 
Khalil MH, Al-Saef AM. Methods, criteria, techiniques and genetique responses for rabbit selection: A review. In: 9 th World Rabbit Congress - June 10-13, 2008 - Verona - Italy.

Larzul C, Gondret F, Combers S, De Romchanbeau H. Analyse d'une expérience de sélection sur le poids á 63 jours: I-Déterminisme génétique de la croissance. In Proc: 10émes Journées de la Recherche Cunicole, 2003.

Lavara R, Vicente JS, Baselga M. 2011.Genetic parameter estimates for semen production traits and growth rate of a paternal rabbit line. J Anim Breed Genet 128 44-51.

Lavara R, Vicente JS, Marco-Jimenez F, Baselga M. 2008. Correlation between casa and plasma parameters in Rabbit semen. 9th World Rabbit Congress 381-386.

Lebas F, Coudert P, Rouveir R, De Rochambeau H. 1997. The rabbit husbandry, health and production. FAO Animal Production and Health Series, Rome.

Legault CF, Menissier P, Merat G, Rilcordeau, Rouvier R. 1996. X. INRA Prod. Anim Hors série 41-56.

Leroy JLMR, Vanholder T, Mateusen B, Christophe A, Opsomer G, de Kruif A, Genicot G, Van Soom A.2005. Non-esterified fatty acids in follicular fluid of dairy cows and their effect on developmental capacity of bovine oocytes in vitro. Reproduction 130 485-495.

Llobat L, Marco-Jiménez F, Peñaranda DS, Thieme R, Navarrete A, Vicente JS. 2012. mRNA expression in rabbit blastocyst and endometrial tissue of candidate gene involved in gestational losses. Reprod Dom Anim 47 281-287.

López M, Sierra I. 2002. The Gigante de España Breed (Spain). Options Méditerranéennes. Série B: Etudes et Recherches (CIHEAM). 
Lorenzo PL, García-García RM, Árias-Álvarez M, Rebollar PG. 2014. Reproductive and nutritional management on ovarian response and embryo quality on rabbit does. Reprod Dom Anim 49 49-55.

MacLaughlin SM, Walker SK, Roberts CT, Kleemann D, McMillen IC. 2005. Periconceptional nutrition and the relationship between maternal body weight changes in the periconceotional period and feto-placental growth in the sheep. J Physiol 565 111-124.

Maertens L and Okerman F. 1988. Le rythme de reproduction intensif en cuniculture. Cuniculture 82 171-177.

Martin B, Golden E, Carlson OD, Egan JM, Mattson MP, Maudsley S. 2008. Caloric restriction: Impact upon pituitary function and reproduction. Ageing Res Rev 7 209-224.

Mehaisen GMK, Vicente JS, Lavara R. 2004. In vivo embryo recovery rate by laparoscopic technique from rabbit does selected for growth rate. Reprod Dom Anim 39 347-351.

Mgheni M, Christensen K. 1985. Selection experiment on growth and litter size in rabbits: II. Two-way selection response for body weight at 112 days. Acta Agric Scand 95 278-286.

Montoudis A, Simoneau L, Brisette L, Forest JC, Savard R, Lafond J. 1999. Impact of cholesterol enriched diet on maternal and fetal plasma lipids and fetal deposition in pregnant rabbits. Life Sci 64 2439-2450.

Moschas S, Chan JL, Mantzoros CS. 2002. Leptin and reproduction: a review. Fertil Steril 77 433-444.

Navarrete-Santos A, Tonack S, Kirstein M, Pantaleon M, Kaye P, Fischer B. 2004. Insulin acts via mitogen-activated protein kinase phosphorylation in rabbit blastocysts. Reproduction 128 517-526.

Oikonomou G, Arsenos G, Valergakis GE, Tsiaras A, Zygoyiannis D, Banos G. 2008. Genetic relationship of body energy and blood metabolites with reproduction in Holstein cows. J Dairy Sci 91 4323-4332. 
Opsina PA, Nydam DV, Stokol T, Overton TR. 2010. Associations of elevated nonesterified fatty acids and $\beta$-hydroxybutyrate concentrations with early lactation reproductive performance and milk production in transition airy cattle in the northeaster United States. J Dairy Sci 93 1596-1603.

Orengo J, Piles M, Rafel O, Ramón J, Gómez EA. 2009. Crossbreeding parameters for growth and feed consumption traits from a five diallel mating scheme in rabbits. J Anim Sci 87 1896-1905.

Pascual JJ, Cervera C, Blas E, Fernandez-Carmona J. 2003. High-energy diets for reproductive rabbit does: effect of energy source. Nutr Abstr Rev 73 27R$39 R$.

Pascual M. Pla M. 2007. Changes in carcass composition and meat quality when selecting rabbits for growth rate. Meat Science 77 474-481.

Parigi-Bini R. 1988. Recent developments and future goals in research on nutrition of intensively reared rabbits. In: Procceedings of $4^{\text {th }}$ World Rabbit Congress, vol.3, Budapest, Hungary, 10-14 Oct. pp. 1-29.

Pasquali R, Casimirri F. 1993. The impact of obesity in hyperandrogenism and polycystic ovary syndrome in premenopausal women. Clin Edocrinol 39 1-16.

Picone O, Laigre P, Fortun-Lamothe L, Archilla C, Peynot N, Ponter AA, Berthelot V, Cordier AG, Duranthon V, Chavatte-Palmer P. 2011. Hyperlipidic hypercholesterolemic diet in prepubertal rabbits affects gene expression in the embryo, restricts fetal growth and increases offspring susceptibility to obesity. Theriogenology 75 287-299.

Picone O, Laigre P, Fortun-Lamothe L, Archilla C, Peynot N, Ponter AA, Berthelot V, Cordier AG, Duranthon V, Chavatte-Palmer P. 2011. Hyperlipidic hypercholesterolemic diet in prepubertal rabbits affects gene expression in the embryo, restricts fetal growth and increases offspring susceptibility to obesity. Theriogenology 75 287-299.

Piles M, Rafel O, Ramon J, Varona L. 2005. Genetic parameters of fertility in two lines of rabbits with different reproductive potential. J Anim Sci 83 340-343. 
Piles M, Gomez EA, Rafel O, Ramon J, Blasco A. 2004. Elliptical selection experiment for the estimation of genetic parameters of the growth rate and feed conversion ratio in rabbits. J Anim Sci 82 654-660.

Piles M, Tusell L. 2011. Genetic correlation between growth and female and male contributions to fertility in rabbit. J Anim Breed Genet 129 298-305.

Pralong FP. 2010. Insulin and NPY pathways and the control of GnRH function and puberty onset. Mol Cell Endocrinol 324 82-86.

Rauw W, Kanis ME, Noordhuizen-Stassen EN, Grommers FJ. 1998. Undesirable side effects of selection for high production efficiency in farm animals: A review. Livest Prod 56 15-33.

Roberts RC. 1979. Side effects of selection for growth in laboratory animals. Livest Prod Sci 6 93-104.

Rochambeau H de, Fuente LF de la, Rouvier R, Ouhayoun J. 1989. Selection sur la vitesse de croissance post-sevrage chez le lapin. Genet Sel Evol $21527-$ 546.

Rommers JM, Meijerhof R, Noordhuizen JPTM, Kemp B. 2004. Effect of feeding program during rearing and age at first insemination on performances during subsequent reproduction in young rabbit does. Reprod Nutr Dev 44 321-332.

Sánchez JP, de la Fuente LF, Rosell JM. 2012. Health and body condition of lactating females on rabbit farms. J Anim Sci 90 2353-2361.

Sjoblom C, Roberts CT, Wikland M, Roberston SA. 2005. GranulocyteMacrophage colony-stimulating factor alleviates adverse consequences embryo culture on fetal growth trajectory and placental morphogenesis. Endocrinology 146 2142-2153.

Smith JT, Acohido BV, Clifton DK, Steiner RA. 2006. KiSS-1 neurons are direct targets for leptin in the ob/ob mouse. J Neuroendocrinol 18 298-303.

Thieme R, Chindler M, Ramin N, Fischer S, Mühleck B, Fischer B, NavarreteSantos. 2012. Insulin growth factor adjustement in preimplantation rabbit 
blastocyst and uterine tissues in response to maternal type 1 diabetes. Mol Cell Endocrinol 358 96-103.

Tortoriello DV, McMinn J, Chua SC. 2004. Dietary-induced obesity and hypotalamic infertility in female DBA/2J mice. Endocrinol 45 1238-1247.

True MW. 2009. Circulating biomarkers of glycemia in diabetes management and implications for personalized medicine. J Diabetes Sci Technol 3 743-747.

Tusell L, Legarra A, García-Tomás M, Rafel O, Ramón J, Piles M. 2011 .Genetic basis of semen traits and their relationship with growth rate in rabbits. JAS 90 1385-1397.

Uenoyama $Y$, Tsukamura $H$, Kinoshita M, Yamada S, Iwata K, Pheng V, Sajapitak S, Sakakibara M, Ohtaki T, Matsumoto H, Maeda KI. 2008. Oestrogendependent stimulation of luteinizing hormone release by galanin-like peptide in female rats. J Neuroendocrinol 20 626-631.

Vanholder T, Leroy JLMR, Van Soom A, Opsomer G, Maes D, Coryn M, de Kruif A. 2005. Effect of non-esterified fatty acids on bovine granulosa cell steroidogenesis and proliferation in vitro. Anim Reprod Sci 87 33-44.

Vicente JS, Viudes-de-Catro MP, García ML, Baselga M. 2003. Effect of rabbit line in a cryopreservation program by vitrification. Reprod Nutr Develop 43 147153.

Vicente JS, Llobat L, Jiménez-Trigos E, Lavara L, Marco-Jiménez F. 2013. Effect of emrbyonic and maternal genotype on embryo and foetal survival in rabbit. Repro Dom Anim 48 402-406.

Vicente JS, Llobat L, Viudes-de-Castro MP, Lavara R, Baselga M, MarcoJiménez F. 2012. Gestational losses in a rabbit line selected for growth rate. Theriogenology 77 81-88.

Wathes DC, Cheng Z, Fenwick MA, Fitzpatrick R, Patton J. 2011. Influence of energy balance on the somatotrophic axis and metalloproteinase expression in the endometrium of the postpartum dairy cow. Reproduction 141 269-281 
Watkins AJ, Ursell E, Panton R, Papenbrock T, Hollis L, Cunningham C, Wilkins A, Perry VH, Sheth B, Kwong WY, Eckert JJ, Wild AE, Hanson MA, Osmond C, Fleming TP. 2008. Adaptative response by mouse early embryos to maternal diet protect fetal growth but predispose to adult onset disease. Biology of Reproduction 78 299-306.

Wolfenson D, Blum O. 1988. Embryonic development, conception rate, ovarian function and structure in pregnant rabbits heat-stressed before or during implantation. Anim Reprod Sci 17 259-270.

Zerani M, Boiti C, Dall'Aglio C, Ceccarelli P, Gobbetti A. 2004. OB receptor in rabbit ovary and leptin in vitro regulation of corpora lutea. J Endocrinol 183279 288.

Zerani M, Boiti C, Dall'Aglio C, Pascucci L, Maranesi M, Becchia G, Mariottini C, Guelfi G, Zampini D, Gobbetti A. 2005. Leptin receptor expression and in vitro leptin actions on prostaglandin release and nitric oxide synthase activity in the rabbit oviduct. J Endocrinol 185 319-325. 



\section{OBJECTIVES}

C. Naturil-Alfonso

Instituto de Ciencia y Tecnología Animal, Laboratorio de Biotecnología de la Reproducción, Universidad Politécnica de Valencia, Valencia, 46022 



\section{OBJECTIVES}

The aim of this thesis was to study and characterize the reproductive performance of a rabbit line selected for growth rate (line R) and examine the long-term effects of two different feeding regimens (ad libitum or restricted) at end of rearing period, in order to improve these reproductive characteristics. To this end, the specific objectives of the thesis were as follows:

In chapter 1, the objective was to determine the maternal and embryonic effects of line $R$ in reproductive performance over the course of pregnancy compared with a maternal line.

The objective in chapter 2 was to explore the causes of ovulation induction failures previously established in females of line $R$, with the premise that an inadequate neuroendocrine reflex at hypothalamus-pituitary system could be the problem.

Chapter 3 was focused on the effect of different nutritional regimens after rearing prior to mating on alterations in gene expression of the hypothalamushypophysis and the quality of the oocytes produced.

The effect of feed restriction at the end of rearing period prior to mating on reproductive performance and embryo development and survival in line $\mathrm{R}$ was studied in Chapter 4.

The last chapter of this thesis aimed to evaluate the influence of two different rearing feeding strategies (ad libitum and restricted) at the end of the rearing period prior to mating on reproductive performance, body composition and circulating metabolic hormones and metabolites in the reproductive performance of line $\mathrm{R}$. 



\section{Role of embryonic and maternal genotype on prenatal}

\section{survival and fetal growth in rabbit}

C. Naturil-Alfonso', F. Marco-Jiménez', E. Jiménez-Trigos', M.D. Saenz-de-Juano' M.P.Viudes-de-Castro², R. Lavara', J.S. Vicente'

'Laboratorio de Biotecnología de la Reproducción, Instituto de Ciencia y Tecnología Animal, Universidad Politécnica de Valencia, Valencia, Spain

${ }^{2}$ Centro de Investigación y Tecnología Animal-Instituto Valenciano de Investigaciones Agrarias (CITA-IVIA), Polígono La Esperanza, Segorbe, Castellón, Spain

Reproduction in Domestic Animals. 2015 50:312-320.

This work was supported by the Generalitat Valenciana research programme (Prometeo II2014 / 036) and by the Spanish Research Project AGL2011-30170-C02-01 (CICYT). Carmen Naturil was supported by a research grant from the Education Ministry of the Valencian Regional Government (programme VALi+d. ACIF / 2013 / 296). 



\section{ABSTRACT}

The aim of this work was to evaluate the influence of maternal and embryonic genotype on prenatal survival and fetal growth during pregnancy. Embryos were recovered at $48 \mathrm{~h}$ of gestation from two different donor lines ( $R=46$ and $A=40$ ) and transferred to nulliparous recipient does (26 R and $24 \mathrm{~A}$ ). Each recipient doe received six embryos into one oviduct from line $\mathrm{R}$ and six embryos form line $A$ into the other. Laparoscopy was performed at day 14 to determine implantation rate. Recipient females were slaughter at day 14, 24 and 30 (12, 24,14 , respectively) to determine the number of live foetuses and the weight of live foetuses, fetal placenta and maternal placenta. A transcriptome analysis was performed to search for differences between fetal placentas at day 14 and 24 of development. Prenatal survival at Days 14 and 24 was affected by embryonic genotype and determined by maternal genotype at Day 30 . Fetal weight at Day 14 was influenced by both genotypes, being the weight higher for group A/A $(0.29 \pm 0.01$ g vs. $0.19 \pm 0.01$ g, for group R/R). However, both genotypes were determinant for fetal placenta weight at Day 24, while those genotypes affected maternal placenta weight at Day 30. Nevertheless, no differences in fetal placenta at transcriptome level and progesterone and IGF-I plasma levels in recipient does were found. In conclusion, results indicate that the influence of embryo and maternal genotype on the prenatal survival and growth seem to be changing over gestation. 



\section{INTRODUCTION}

Embryo development and survival, as well as a successful pregnancy, are dependent on a well-established and functional placenta. Yet the influence of embryonic and maternal genotypes on placental weight is controversial. While both genotypes had an influence on fetal and placenta weight in mouse and pig (Al-Murrani and Roberts, 1978; Barkley and Fitzgerald, 1990; Biensen et al., 1998; Wilson et al., 1998), Mocé et al. (2004a) stated that fetal weight in the last term of gestation depends on the maternal genotype, and fetal-placental weight depends on the embryonic genotype in rabbit. However, recently Vicente et al. (2013) showed that embryonic genotype affects fetal weight, but both embryonic and maternal genotype affect fetal-placental weight in the last term of gestation. In fact, fetal growth in late gestation is dependent upon the correct growth and development of the placenta (Chaddha et al., 2004). The establishment of a healthy and functional placenta is a crucial element in the embryonic and fetal development. The development and interrelationships between maternal and fetal vascular networks in the placenta is critical for the successful development of the offspring (Yllera et al., 2003).

Therefore, due to the relevant role of the placenta and the fetal-placental interface, several works have focused in the study of placenta transcriptome (Buffat et al., 2007; Zhou et al., 2009; Salilew-Wondim et al., 2013; Whitehead et al., 2013; Gu et al., 2014). The advantage of microarray analysis is the simultaneous measurement of the expression patterns of large numbers of genes (Lockhart et al., 1996). These studies showed differences at transcriptomic level between porcine placentas with different placental efficiency (Zhou et al., 2009; Gu et al., 2014), placentas with intrauterine growth 
restriction and fetal growth restriction (Buffat et al., 2007; Whitehead et al., 2013), and between bovine placentas derived from artificial insemination, in vitro fertilization and somatic cell nuclear transfer (Salilew-Wondim et al., 2013).

In this work, we set out to evaluate the effect of maternal and embryonic genotype on prenatal survival and placenta and fetal weights over the course of pregnancy. In addition, fetal placenta transcriptome at Days 14 and 24 of pregnancy was addressed.

\section{MATERIAL AND METHODS}

All chemicals in this study were purchased form Sigma-Aldrich Química S.A. (Madrid, Spain) unless stated otherwise.

\section{Ethical Statement}

The Ethics and Animal Welfare Committee of the Polytechnic University of Valencia approved this study. All animals were handled according to the principles of animal care published by Spanish Royal Decree 53/2013.

\section{Animals}

Animals used as donors and recipients came from two commercial lines generated at the Universidad Politécnica de Valencia. One (named line R) is a synthetic line selected since 1990 by individual selection on daily weight gain from weaning to slaughter age (28 and 63 days, Estany et al., 1992) and the other one (named line A) came form a New Zealand White selected since 1980 by a family index for litter size at weaning (Estany et al., 1989). Animals were kept under controlled (16 h light : $8 \mathrm{~h}$ dark) photoperiod and fed with a commercial rabbit diet (on dry matter basis: $17.5 \%$ crude protein, $3.5 \%$ ether extract, $16.7 \%$ crude fiber, $2938 \mathrm{kcal} / \mathrm{kg})$. 


\section{Embryo transfer}

The scheme for the embryo transfer procedure is presented in Figure 1.1. At the age of five months, a total of 86 nulliparous does were used as donor females; 46 does from the line $R$ and 40 does from the line A. Does were injected 25 IU of eCG intramuscular (Intervet International B.V., Bowmeer-Holland) to induce receptivity. After 48 hours, females were artificially inseminated with a heterospermic pool of fertile males from the same selected line to randomise male effect. At the time of artificial insemination, females were injected with 1 $\mu \mathrm{g}$ of buserelin acetate (Hoechst, Marion Roussel, Madrid, Spain) to induce ovulation. Then, does were slaughtered 48 hours after insemination. Embryos were collected at room temperature by flushing the oviducts and the first onethird of the uterine horns with $5 \mathrm{~mL}$ of embryo recovery media consisting of Dulbecco's Phosphate-Buffered Saline (DPBS) supplemented with $0.2 \%(\mathrm{w} / \mathrm{v})$ bovine serum albumin (BSA) and antibiotics (penicillin G sodium 300,000 IU, penicillin G procaine 700,000 IU, and dihydrostreptomycin sulphate $1250 \mathrm{mg}$; Penivet 1; Divasa Farmavic, Barcelona, Spain). After recovery, morphologically normal embryos (classified as normal when they presented correct developmental stage, homogeneous cell size and cytoplasm aspect, and spherical zona pellucida and mucin coat) were kept at room temperature (20$25^{\circ} \mathrm{C}$ ) in dark light until transfer to recipient females.

A total of 600 embryos were transferred. Receptive females (according to the turgidity and colour of the vulva) were induced to ovulate by injection of $1 \mu \mathrm{g}$ of buserelin acetate (Hoechst, Marion Roussel, Madrid, Spain) 48 hours before transfer. Females were anaesthetised by intramuscular injection of $5 \mathrm{mg} / \mathrm{kg}$ of xylazine (Rompún, Bayer AG, Leverkusen, Germany) following intravenous 
injection of $15 \mathrm{mg} / \mathrm{kg}$ ketamine hydrochloride (Imalgène, Merial SA, Lyon, France). Embryo transfer was performed using the laparoscopic technique described by Besenfelder and Brem (1993). At the age of 5 months, a total of 26 nulliparous females from line $\mathrm{R}$ and 24 from line $\mathrm{A}$ were used. The number of embryos transferred per oviduct was standardised to 6, so that all recipients received 12 embryos (six embryos from line $\mathrm{R}$ into one oviduct and six embryos from line $A$ into the other). Transfers to right or left uterine horns were randomised. According to the transfers, four groups were obtained:

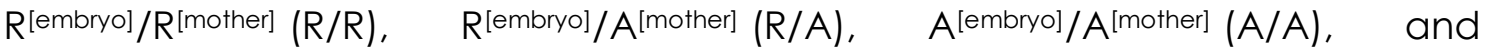
$A^{[\text {embryo] }} / R^{[\text {mother] }}(A / R)$.

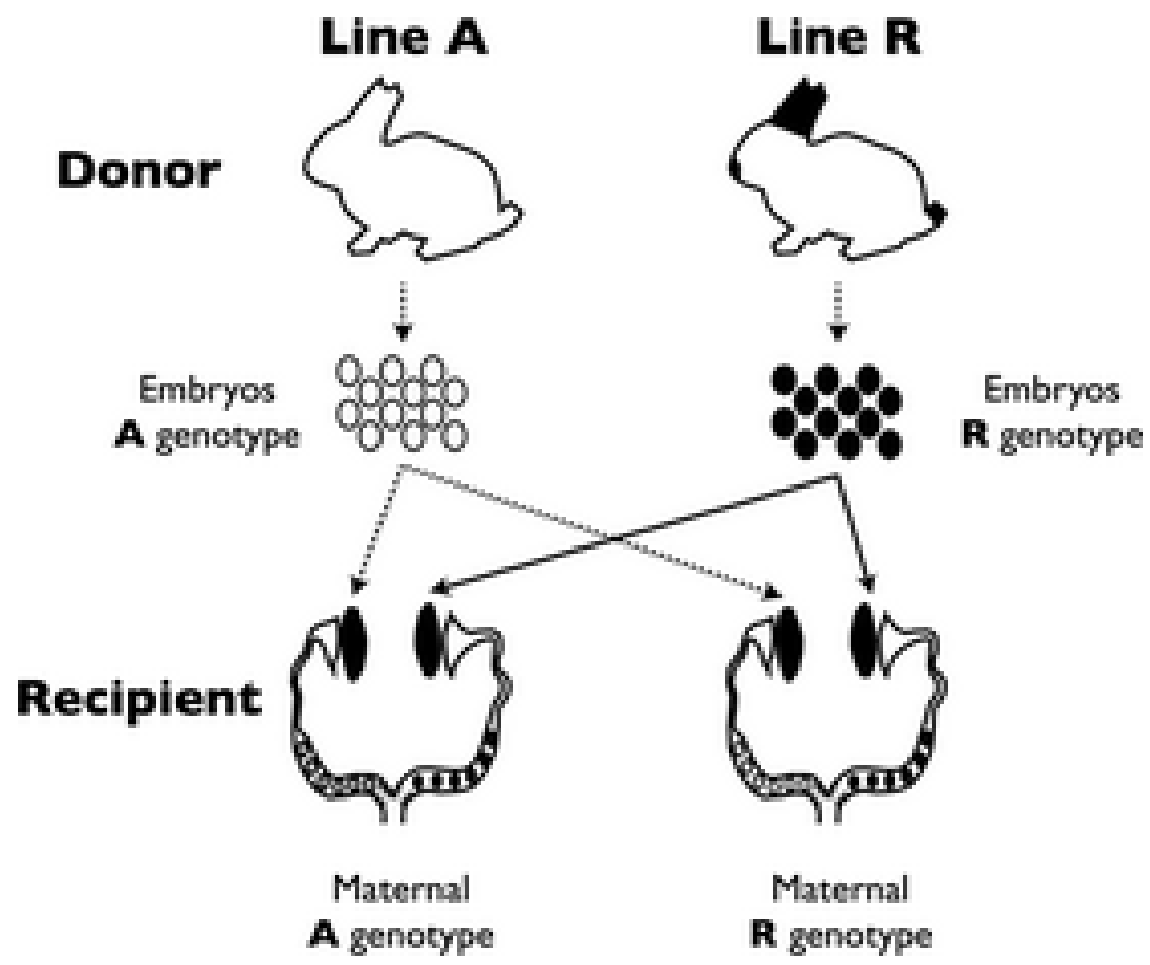

Figure 1.1. Schematic illustration of the embryo transfer model used in this study to determine maternal genotype and fetal genotype effect on prenatal survival and fetal growth. $A / R(A)$ embryo transferred into $R$ foster mother; $R / R(R)$ embryo transferred into $R$ foster mother; R/A (R) embryo transferred into A foster mother; $A / A$ (A) embryo transferred into A foster mother. Transferred embryos were gestated in foster mothers for 14,24 and 30 days and then collected to record prenatal survival, fetal and placental weights. 


\section{Prenatal survival rate and samples at Day 14,24 and 30}

Implantation rate in each horn (number of implanted embryos at Day 14 from total embryos transferred) was assessed by laparoscopy, according to the procedure previously described (Llobat et al., 2012; Vicente et al., 2012). Recipient females were sequentially euthanized at Day $14(n=12)$, Day 24 $(n=24)$ and Day $30(n=14)$. Then, prenatal survival was assessed, and live foetuses were weighted after placental membranes and fluids were removed. Fetal placenta and adjacent maternal placenta from each foetus were dissected separately and individually weighted. Samples from fetal placental tissue were stored for RNA expression analysis at $-80^{\circ} \mathrm{C}$.

\section{RNA Extraction}

PolyA RNA was extracted from fetal placental tissue at Day 14 and Day 24 of group RR and group AA.

In the case of Day 14 fetal placentas, total RNA was isolated from 10 samples per experimental group. In the case of Day 24 fetal placentas, seven samples per experimental group were used. A traditional phenol/chloroform extraction by sonication in the Trizol reagent was performed. Then, RNA was purified by RNA Clean-up columns (Nucleospin, Madrid, Spain), and concentration, quality and integrity of RNA were evaluated by Nanodrop 1000 and Bioanalyzer 2100 (Agilent Technologies, Madrid, Spain). 


\section{Microarray analysis}

For the two-colour microarray analysis, four biological replicates were used Day 14 fetal placentas, including two dye swaps to compensate dye-bias. For Day 24, four biological replicates were used including one dye-swap.

Total RNA (100 ng) was amplified using QuickAmp Labelling Kit (Agilent Technologies, Madrid, Spain), following manufacturer's instructions. The complementary RNA (CRNA) generated was purified and labelled with Cyanine 3 dye (Cy3) and Cyanine 5 dye (Cy5). Excess dye was removed with the QIAquick PCR purification kit (Qiagen Iberia S.L, Madrid, Spain) and dye incorporation and concentration were determined using the microarray setting on the Nanodrop 1000. Equal amounts of Cy3 and Cy5 labelled samples (825 ng) were mixed with 10X Blocking Agent and Fragmentation Buffer, and then 55 $\mu \mathrm{L}$ of the mixture were hybridised into the Rabbit $44 \mathrm{X}$ oligonucleotide array G2519F (Agilent Technologies, Madrid, Spain). After 17 hours at $65^{\circ} \mathrm{C}$, hybridised slides were washed and scanned using the Agilent DNA Microarray Scanner G2565B (Agilent Technologies, Madrid, Spain). The resulting images were processed using Feature Extraction v.10 Software (Agilent Technologies, Madrid, Spain) with default parameters. Normalization with the locally weighted linear regression (LOWESS) algorithm and identification of differentially expressed transcripts was achieved using the Limma package in R (www.r-project.org). Pvalues were adjusted for multiple testing using the Benjamini and Hochberg false discovery rate (FDR), and differences of $\mathrm{P}<0.05$ were considered significant. All data sets related to this study were deposited in NCBl's Gene Expression Omnibus and are accessible through GEO Series accession number GSE62491. 


\section{RT-PCR}

To validate the microarray results RT-PCR for six genes (VEGF, ERBB3, TGFB2, IGFI, ITGA 1, INFG) were carried out in 20 independent samples for Day 14 fetal placentas and 14 samples Day 24 fetal placenta. To prevent DNA contamination, one deoxyribonuclease treatment step (gDNA Wipeout Buffer, Qiagen Iberia S.L, Madrid, Spain) was performed from total RNA (1000 ng). Afterwards, reverse transcription was carried out using Reverse Transcriptase Quantitect kit (Qiagen Iberia S.L, Madrid, Spain) according to the manufacturer's instructions. Real-time PCR reactions were conducted in an Applied Biosystems 7500 (Applied Biosystems, Foster City, CA). Every PCR was performed from $5 \mu \mathrm{L}$ diluted 1:20 cDNA template, $250 \mathrm{nM}$ of forward and reverse primers (Table 1.1) and $10 \mu \mathrm{L}$ of PowerSYBR Green PCR Master Mix (Fermentas GMBH, Madrid, Spain) in a final volume of $20 \mu \mathrm{L}$. The PCR protocol included an initial step of $50^{\circ} \mathrm{C}(2 \mathrm{~min})$, followed by $95^{\circ} \mathrm{C}(10 \mathrm{~min})$ and 40 cycles of $95^{\circ} \mathrm{C}(15 \mathrm{~s})$ and $60^{\circ} \mathrm{C}(60 \mathrm{~s})$. After real-time $\mathrm{PCR}$, a melting curve analysis was performed by slowly increasing the temperature from $65^{\circ} \mathrm{C}$ to $95^{\circ} \mathrm{C}$, with a continuous registration of changes in fluorescent emission intensity. The products of RT-PCR were confirmed by bromure ethide-stained $2 \%$ agarose gel electrophoresis in 1x Bionic buffer (Sigma Aldrich Química S.A, Alcobendas, Madrid, Spain). Serial dilutions of cDNA pool made from several samples were done to assess PCR efficiency. A $\triangle \triangle C$ t method adjusted for PCR efficiency was used, employing the geometric average of $\mathrm{H} 2 \mathrm{AFZ}(\mathrm{H} 2 \mathrm{~A}$ histone family member Z) and GAPDH (glyceraldehyde-3-phosphate dehydrogenase) as housekeeping normalization factor (Weltzien et al., 2005). Relative expression of cDNA pool from various samples was used as the calibrator to normalize all samples within one RT-PCR run or between several runs. 


\section{Progesterone and IGF I serum levels}

Whole blood was collected from 14 females at Day 14, 21 and 28 of gestation with the aid of a Vacutainer-heparin tube (LH/Li Heparin Tube TAPVAL®, MonLab, SL. Barcelona, Spain). Blood was centrifuged (1500 x g, 10 min at $\left.4^{\circ} \mathrm{C}\right)$ and plasma was stored at $-80^{\circ} \mathrm{C}$ until assaying. Plasma levels of progesterone (steroid C21, preg-4-ene-3,20-dione) and Insulin-like Growth Factor-I (IGF-I) were determined by direct enzyme immunoassay technique following the manufacturer's instructions (Rabbit Progesterone Elisa Test, Endocrine Technologies, Inc. Newark, USA; IGF-I Elisa Kit, Diagnostic Systems Laboratories, Inc. Texas, USA). Sensitivities of the tests used were $0.1 \mathrm{ng} / \mathrm{mL} \mathrm{mL}$ for progesterone, and $1.1 \mathrm{ng} / \mathrm{mL}$ for IGF-I. 


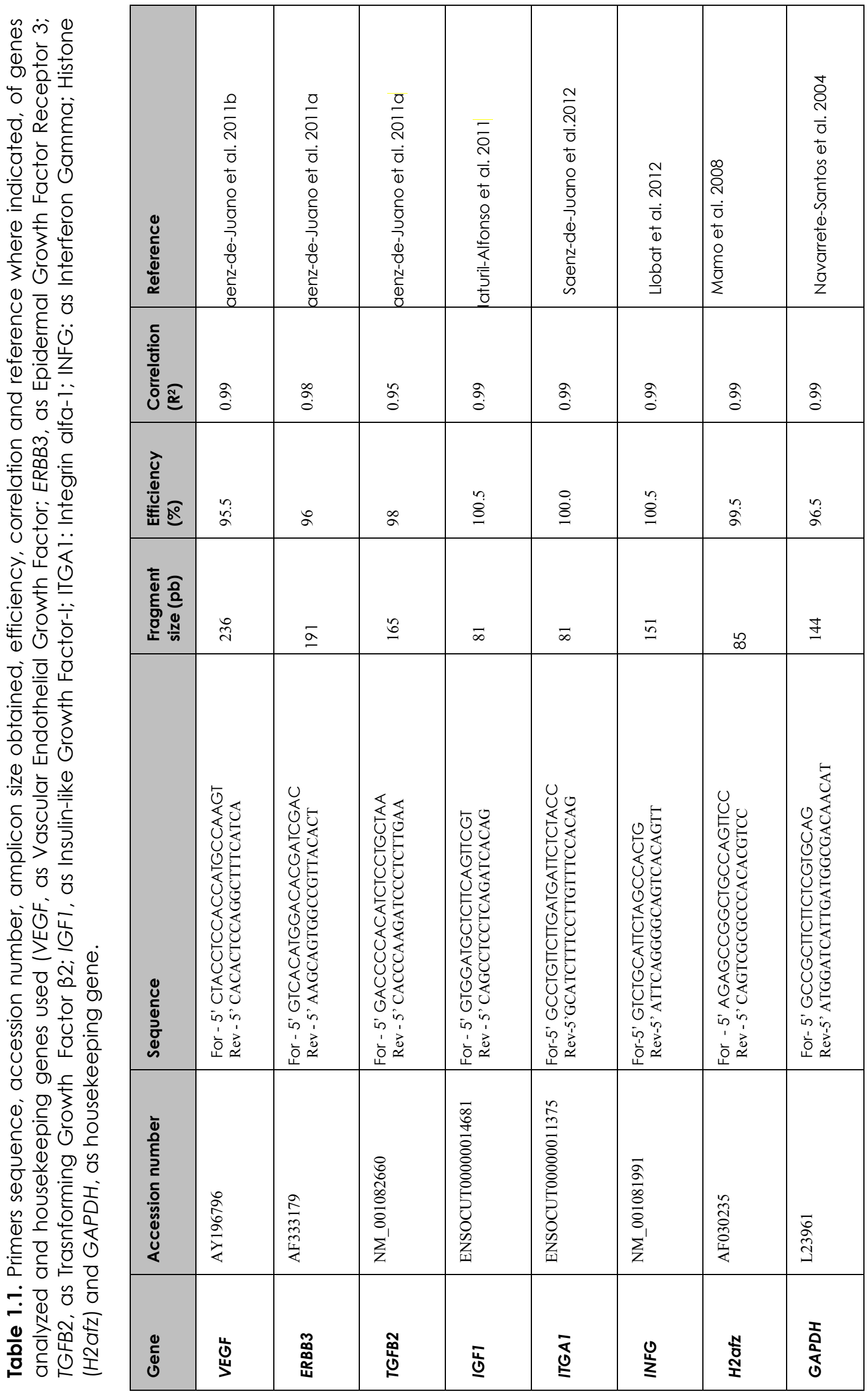




\section{Statistical analysis}

All traits were analysed by a generalised linear model (GLM), using the SPSS software package, version 16.0 (SPSS Inc, Chicago Illinois, USA 2002). Results are reported as least square means \pm SEM. Means were considered statistically different at $P \leq 0.05$.

A probit link function was used to determine the effect of maternal and embryonic genotypes on implantation rate and fetal survival at Day 14 and 24 and 30 of gestation, respectively. The GLM fitted to analyse these traits included as fixed effects the embryonic genotype ( $R$ or $A)$, maternal genotype ( $R$ or $A)$ and their interactions (groups RR, RA, AR, AA). Number of implanted embryos at Day 14 per recipient was included as a covariate in the analysis of fetal survival at Day 24 and 30.

To analyse the fetal and placental (foetus and maternal) weights were analyzed with a GLM including as fixed factors maternal genotype ( $R$ or $A$ ), gestation day $(14,24,30)$ and their interaction was used. Progesterone and IGFI plasma levels, were also analyzed with a GLM including as fixed factors maternal genotype (R or A), gestation day $(14,21,28)$ and their interaction. Moreover, placenta and fetal weights were analysed including the current number of live foetuses at Day 14, 24 and 30 of gestation as covariate.

Data of relative mRNA abundance were normalised by a Nepierian logarithm transformation and evaluated using a GLM too. 


\section{RESULTS}

\section{Prenatal survival rate}

Prenatal survival rate was affected by embryonic genotype at Day 14 and 24 but not at Day 30. The total implantation rate at Day 14 was $0.75 \pm 0.04$ of total transferred embryos (447/600). The implantation rate was lower for embryonic genotype $R(0.57 \pm 0.04$ and $0.69 \pm 0.04$, for genotype $R$ and $A$, respectively, Figure 1.2). These embryonic effects were also observed at Day 24 (Figure 1.2 A).
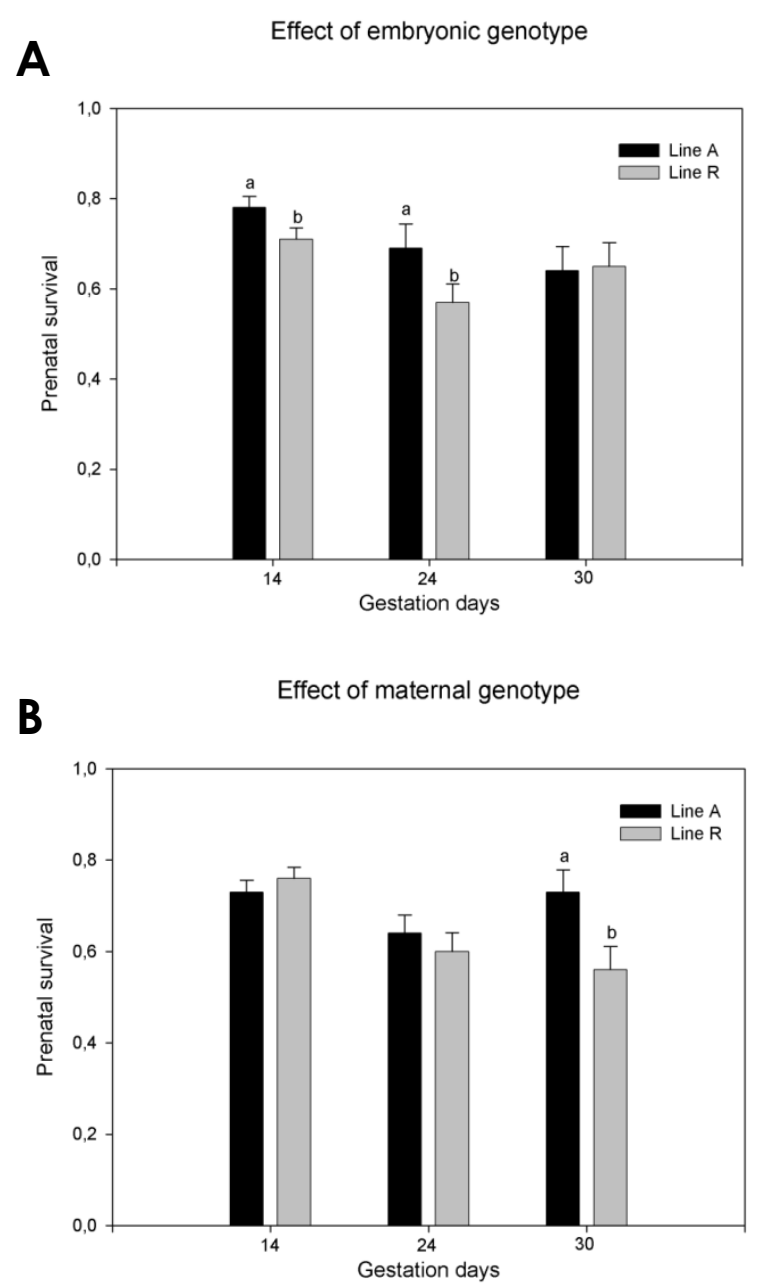

Figure 1.2. Prenatal survival at Day 14,24 and 30 for the different lines. A: Fetal survival for the embryonic genotype effect; B: Fetal survival for the maternal genotype effect. 
Nevertheless, when the number of implanted embryos at Day 24 was included as a covariate, a significant interaction between both genotypes was observed. Concretely, group R/R presented lower live fetuses rate $10.48 \pm 0.05$ vs. $0.68 \pm 0.04,0.60 \pm 0.05,0.70 \pm 0.05$, for genotypes interaction $A / A, A / R$ and R/A, respectively, Figure 1.3). At Day 30, maternal genotype influenced the prenatal survival; maternal genotype A presented a higher prenatal survival rate $(0.73 \pm 0.05$ vs. $0.56 \pm 0.05$, genotype $A$ vs. genotype $R$, respectively, Figure $1.2 \mathrm{~B})$.

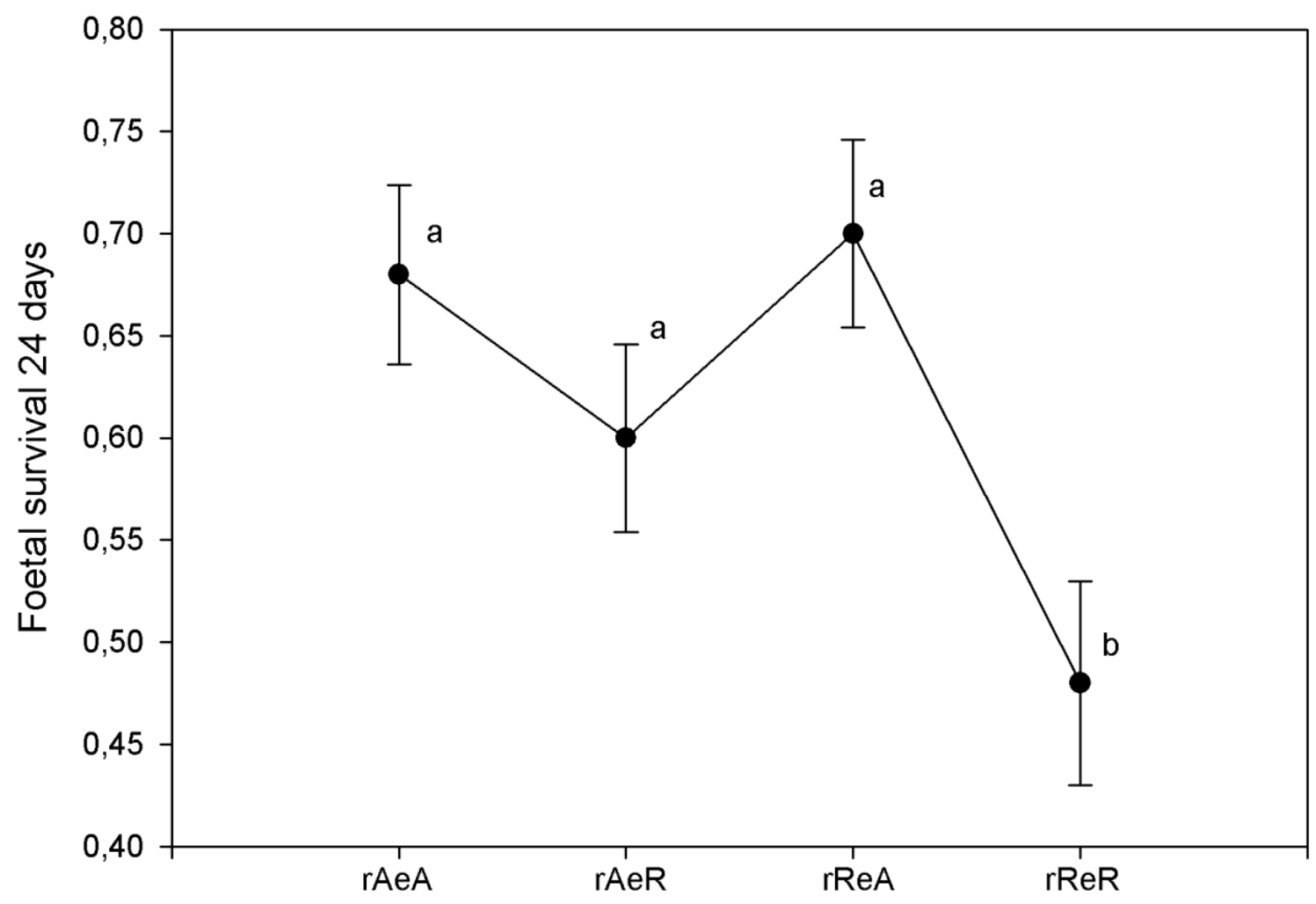

Figure 1.3. Interaction of fetal survival at Day 24 when the covariate implantation rate is included, for: group A/A (A[embryo]/A[mother]), group A/R (A[embryo]/R[mother]), group R/A (R[embryo]/A[mother]) and group R/R (R[embryo]/R[mother]). a,b values are statistically different (p-value < 0.05). 


\section{Fetal and placental weight}

Both fetuses and placentas (fetal and maternal) were weighted at Day 14, 24 and 30 (Figure 1.4).
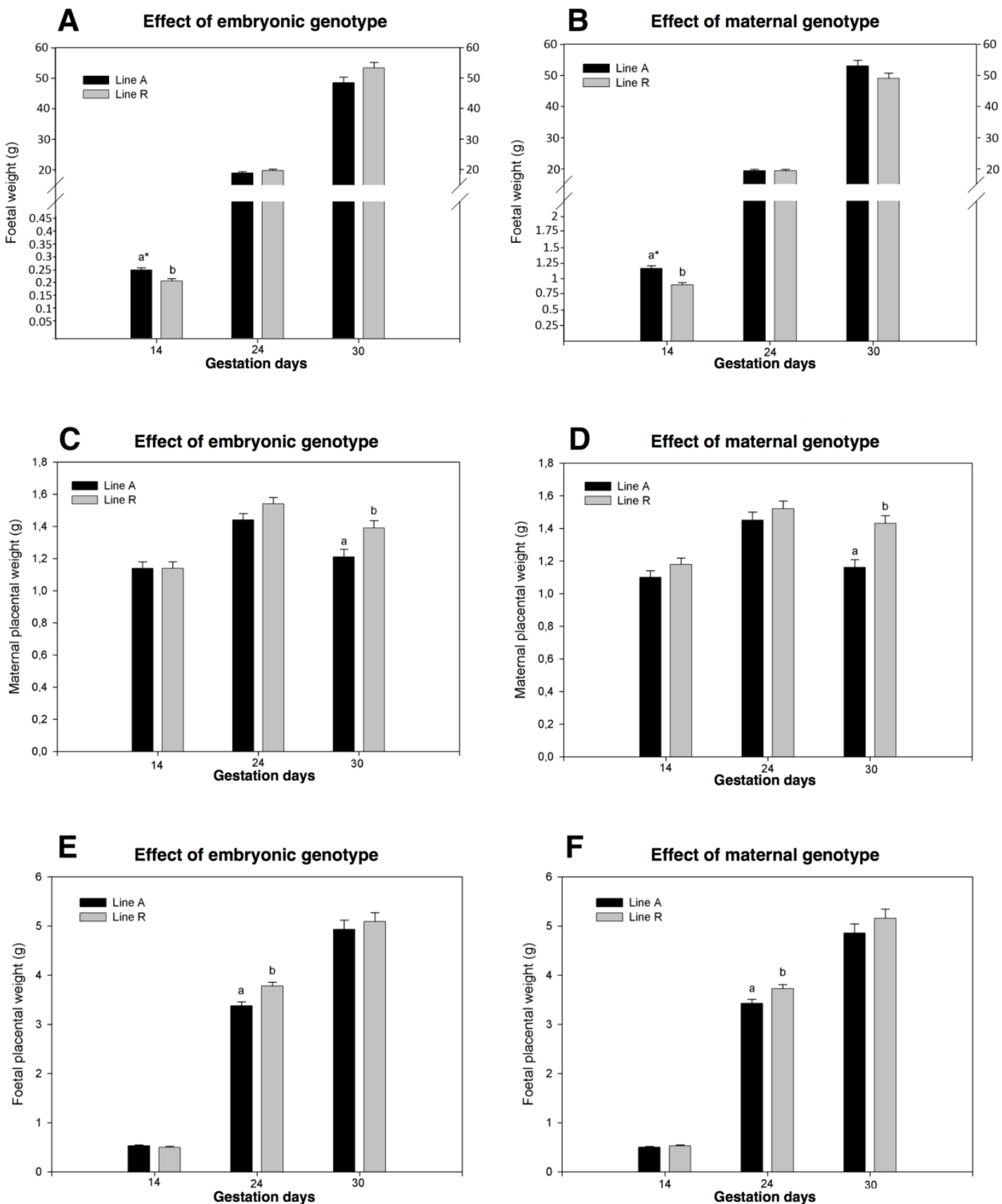

Figure 1.4. Fetal and placental (fetal and maternal) weights at Day 14, 24 and 30 of gestation. A: Fetal weight for embryonic genotype effect; B: Fetal weight for maternal genotype effect; C: Fetal placenta weight for embryonic genotype effect; D: Fetal placenta weight for maternal genotype effect; E: Maternal placenta weight for embryonic genotype effect; F: Maternal placenta weight for maternal genotype effect. $a, b$ values are statistically different ( $p$-value $<0.05$ ). 
Fetal weight at Day 14 was affected by both embryonic and maternal genotypes (Figure 1.4 A and B, respectively). Specifically, the interaction showed that group $A / A$ has higher weight, while group R/R showed lower weight $(0.29 \pm 0.01 \mathrm{~g}$ vs. $0.19 \pm 0.01 \mathrm{~g}$, respectively, Figure 1.5). However, fetal weight at Day 24 did not vary between the embryonic and maternal genotype (Figure 1.4 A and B). At Day 30 foetus weight was almost significantly affected by the embryonic genotype (p-value=0.054), being higher for embryonic genotype R $(53.40 \pm 1.74 \mathrm{~g}$ and $48.50 \pm 1.81 \mathrm{~g}$, for embryonic genotype R and $\mathrm{A}$, respectively, Figure 1.4 A).

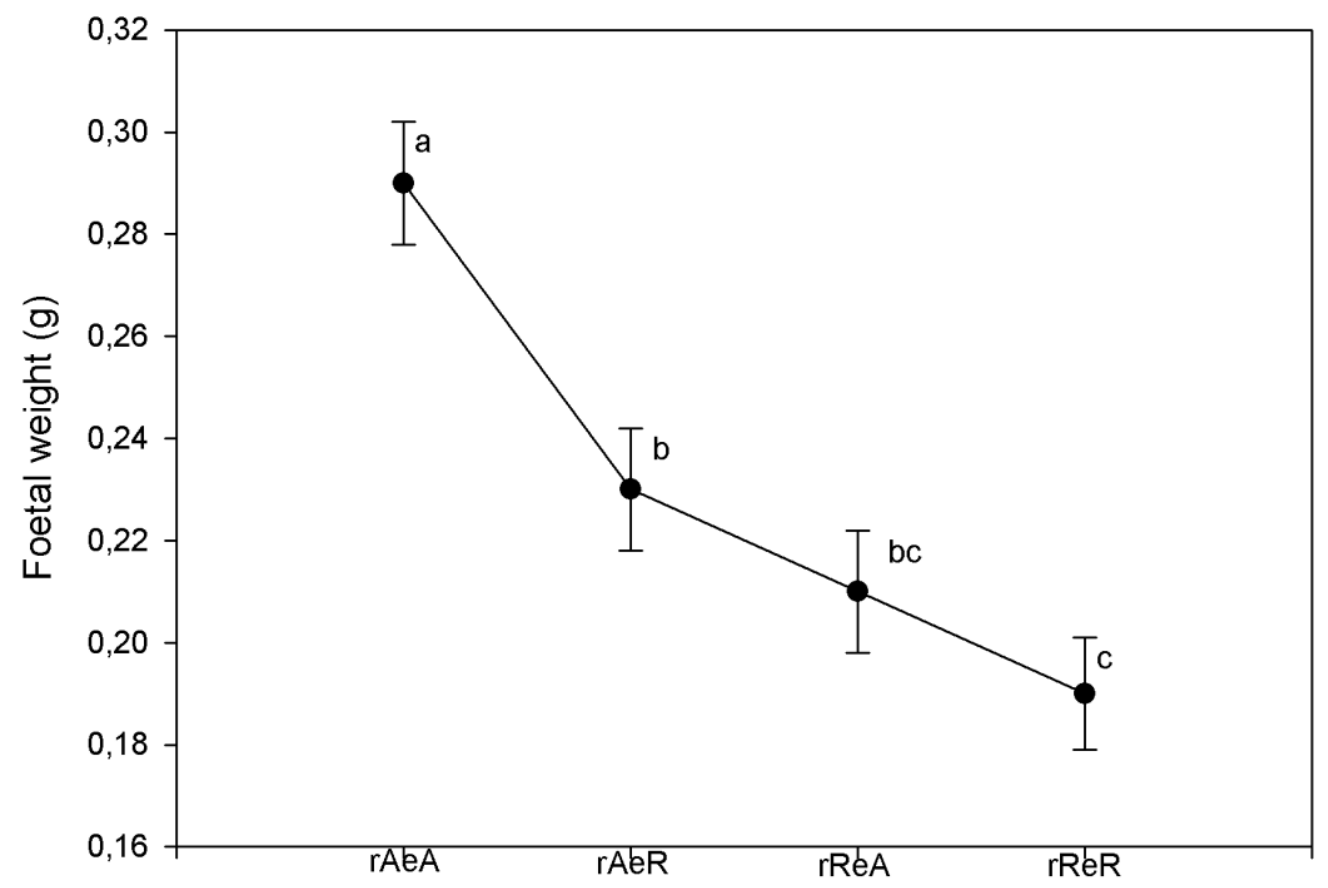

Figure 1.5. Interaction of fetal weight at Day 14 for: group $A / A$ (A[embryo]/A[mother]), group $A / R$ (A[embryo]/R[mother]), group R/A (R[embryo]/A[mother]) and group $R / R$ (R[embryo]/R[mother]). $a, b, c$ values are statistically different ( $p$-value $<0.05)$.

When maternal placental weight was compared, we did not observe differences at Day 14 (Figure 1.4 C, D), but when the number of implanted 
embryos was included as covariate, maternal genotype became significant, being higher for maternal genotype R (1.24 $\pm 0.05 \mathrm{~g}$ vs. $1.04 \pm 0.05 \mathrm{~g}$, genotype $R$ and line A, respectively, Figure 6). However, at Day 24 maternal placental weight was similar for the embryonic and maternal genotype (Figure 1.4 C and D). Conversely, maternal placental weight presented differences for the embryonic and maternal genotype at Day 30 (Figure 1.4 C and D), being heavier for embryonic and maternal genotype $R(1.39 \pm 0.05 \mathrm{~g}$ and $1.52 \pm 0.05$ $\mathrm{g}$, respectively) than for genotypes $\mathrm{A}(1.21 \pm 0.05 \mathrm{~g}$ and $1.45 \pm 0.05 \mathrm{~g}$, for embryonic and maternal genotypes, respectively). Nevertheless, the interaction between embryonic and maternal genotype was not significant. Respect to the fetal placental weight at Day 14 was similar for embryonic and maternal genotypes. However, at Day 24, the weight was affected by both embryo and maternal genotype, being higher for the group R/R $(3.92 \pm 0.12 \mathrm{~g}$ vs. $3.23 \pm 0.11 \mathrm{~g}$, for group R/R and A/A, respectively, Figure $1.4 \mathrm{E}$ and F). On the contrary, fetal placental weight at Day 30 did not present differences for the embryonic and maternal genotype (Figure 1.4 E and F).

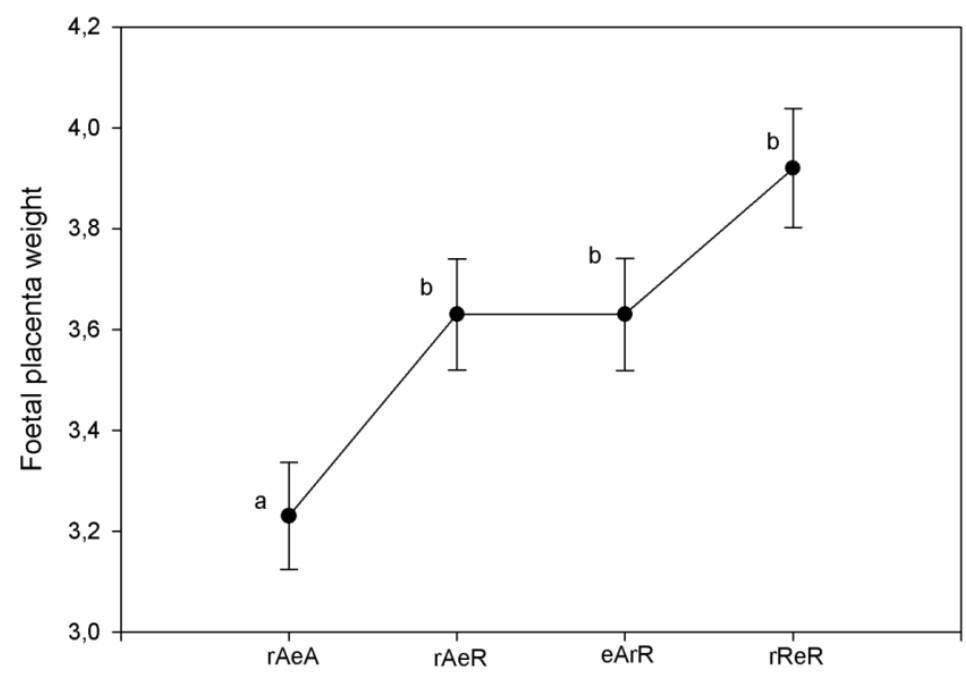

Figure 1.6. Interaction of fetal placenta weight at Day 24 for group $A / A$

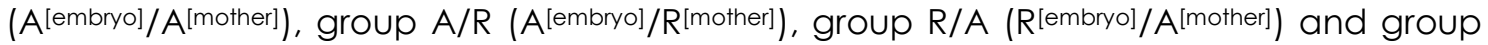
$R / R$ (R[embryo]/R[mother]). $a, b$ values are statistically different ( $p$-value $<0.05)$. 


\section{Effect of group (R/R and $A / A)$ on fetal placental gene expression at Day 14 and Day 24}

Limma analysis after normalization did not reveal any significant changes in gene expression, neither at Day 14 not at Day 24. A total of six genes represented on the microarray (VEGF, ERBB3, TGFB2, IGF1, ITGA 1, INFG) were selected and tested using RT-PCR. These genes were selected because they represent likely important moments as embryo development, implantation events and placenta formation. According to microarray results, no significant differences were observed between groups neither at Day 14 not at Day 24 (Figure 1.7 and 1.8, respectively).

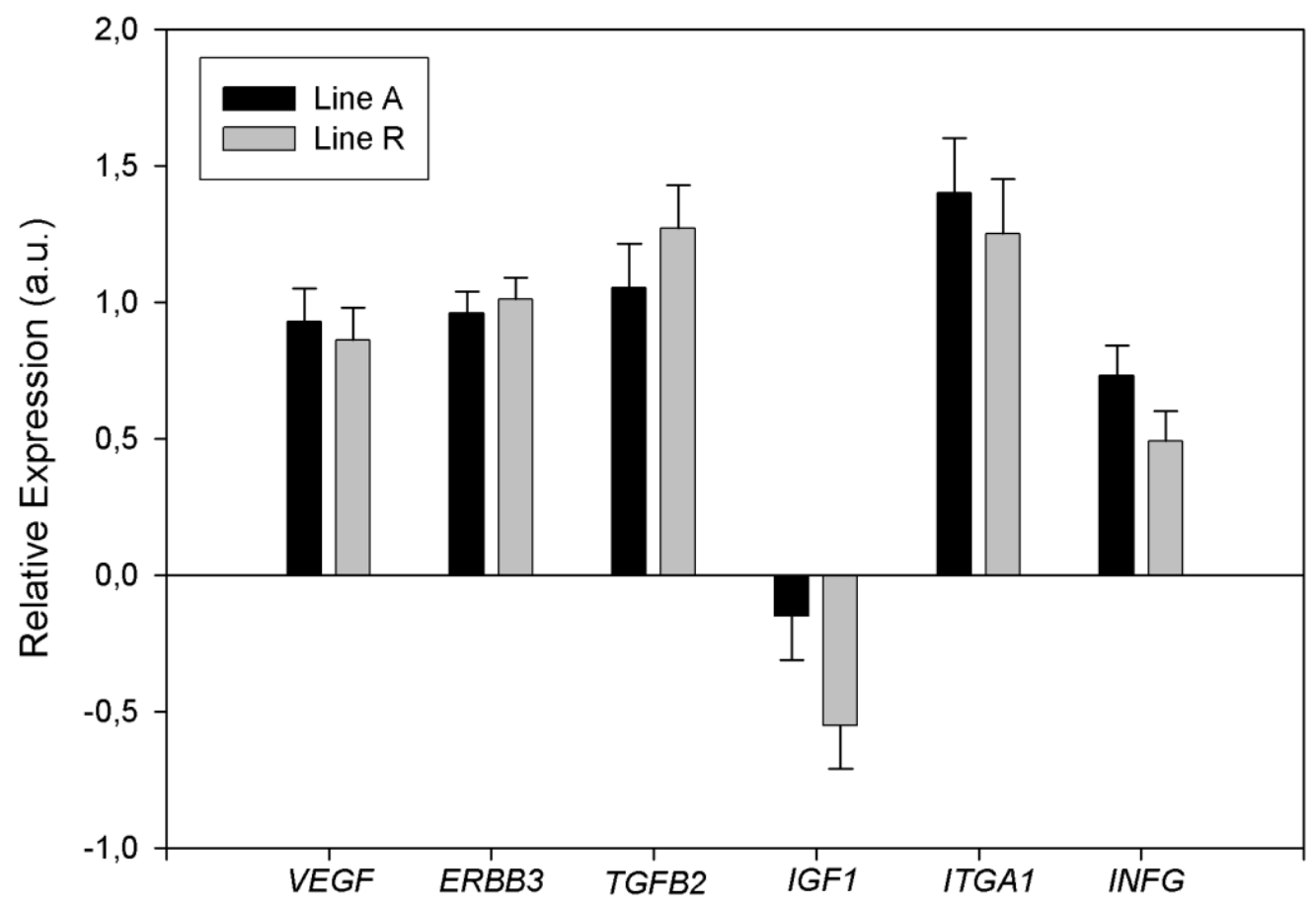

Figure 1.7. Relative expression of vascular endothelial growth factor (VEGF), Epidermal Growth Factor receptor 3 (eRBB3), Transforming Growth Factor-B2 (TGFB2), Insulin-like Growth Factor I (IGFI), Integrin alpha-I (ITGAI) and Interferon-gamma (IFNG) for validation of Day 14 fetal placentas microarray. Relative abundance values are shown in arbitrary units (a.u), expressed by the mean value \pm standard error means. 


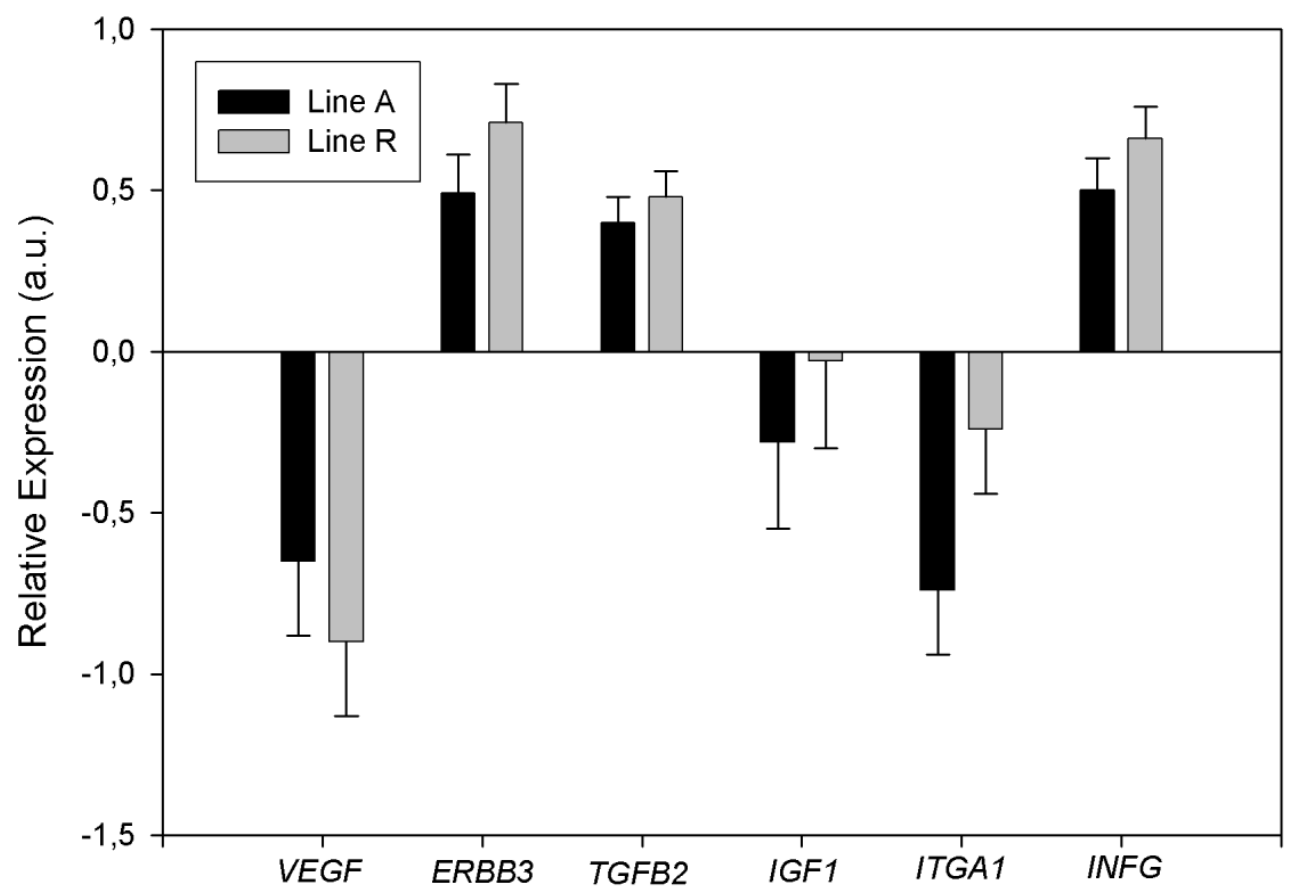

Figure 1.8 Relative expression of vascular endothelial growth factor (VEGF), Epidermal Growth Factor receptor 3 (eRBB3), Transforming Growth Factor-B2 (TGFB2), Insulin-like Growth Factor I (IGFI), Integrin alpha-I (ITGAI) and Interferon-gamma (IFNG) for validation of Day 24 fetal placentas microarray. Relative abundance values are shown in arbitrary units (a.u), expressed by the mean value \pm standard error means.

\section{Effect of maternal genotype on progesterone and IGF1 levels}

Progesterone plasma levels at Day 14,21 and 28 of gestation were similar between maternal genotypes $R$ and $A$, with higher levels at Day 14 and decreasing levels at days 21 and 28 of gestation (Figure 1.9 A). As well, plasma levels of IGFI were not different between recipients of the different lines at Day 14, 21 and 28, with lower levels at Day 14 and reaching higher levels at Day 21 and 28 (Figure $1.9 \mathrm{~B}$ ). 

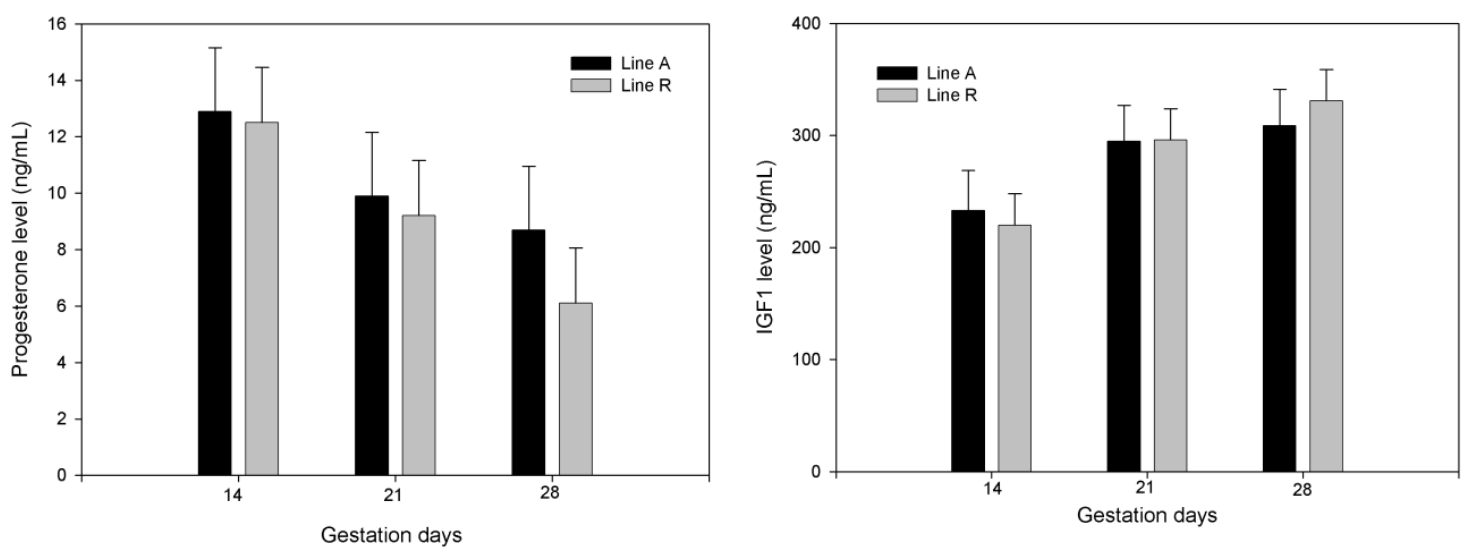

Figure 1.9. Effect of maternal genotype on progesterone and IGFI serum levels at Day 14, 21 and 28 of gestation. A: Progesterone levels; B: IGF1 levels.

\section{DISCUSSION}

Survival and fitness of offspring depend on complex systems of provisioning resources between parents and offspring, resulting in intricate coadaptations to variations in supply and demand (SenthamaraiKannan et al., 2011). In eutherian mammals, fetal growth and epigenetic preadaptive responses for birth depend on the proper function of the placenta, which acts as an interface between the mother and foetus. Many studies describing genetic differences in prenatal survival in polytocous species have been performed (Brien, 1986; Blasco et al., 1993; Argente et al., 2003; Holt et al., 2004; Mocé et al., 2004b; Foxcroft et al., 2006; Freking et al., 2007; Laborda et al., 2012; Vicente et al., 2012; 2013). However, few studies have been done to elucidate how maternal genotype, embryonic genotype and their dialogue can modify survival rate over the course of pregnancy. To examine this, we studied the effect of embryonic and maternal genotype at different stages of pregnancy (Day 14, 24 and 30) by reciprocal transfers. The embryo transfer model that we used has the following advantages: (i) two fetal genotypes are transferred into two different maternal genotypes, which allows us to study the fetal and maternal genotype effects, 
(ii) the female rabbit has a uterus formed by two independent horns (each horn possess its own cervix) and it have advantages in identification of the offspring and (iii) laparoscopic embryo transfer is a non-invasive and feasible technique.

Our results show that at Day 14 the fetal survival was significantly regulated by the embryonic genotype but not the maternal genotype. This finding correlates with previous studies (Youngs et al., 1994; Ernst et al., 2000, in mouse, Ashworth et al.. 1990; Kaminski et al., 1996, in swine and Vicente et al., 2013 in rabbits). However, at Day 24, when the covariate implantation rate was included fetal and maternal genotype interaction was determined, while at Day 30 (last term of gestation) occurs a change and fetal survival was significantly regulated by the maternal genotype. Mocé et al. (2004b), working with rabbits divergently selected by high and low uterine capacity found an interaction between both genotypes at Day 28. These authors suggest that the embryonic genotype had an effect on fetal survival only in a favorable maternal genotype. These results are in agreement with those reported by Moler et al. (1981), who detected a recipient and recipient $x$ donor interaction effect on survival in mice to term. In our case, we did not observe this effect at post-implantation stages. Maybe, the relevant differences in the selection criteria of lines used in this study would explain this discrepancy.

In terms of fetal and placental weights, our results show that at Day 14 the fetal weights were significantly regulated by both maternal and embryonic genotypes. This findings correlates with previous studies that showed that maternal genotype has been described as the key factor in determining fetal weight (Pomp et al., 1989; SenthamaraiKannan et al., 2011). Yet our results suggest that embryonic genotype may also influence fetal weight after 
implantation, and the maternal placenta weight. When the pregnancy progresses (at Day 24), these effects of the influence of embryonic and maternal genotypes on fetal weights and the maternal placental weights were not observed. Nevertheless, at last term of gestation (Day 30), maternal genotype seems to take a role, increasing embryo mortality. Thus, at Day 30 also appears an effect of maternal genotype, which indicates that the recipient endometrium also plays a relevant role at the last term of gestation. However, when we studied two endocrine factors highly related to the development and maintenance of the endometrium and to the mobilization of maternal resources for gestation, we did not observe differences between both maternal genotypes. Inspite of this, specifically, R/R presented higher maternal placental weight than the other groups, being group A/A the one with lowest maternal placental weight. This could be a sign of placentomegaly to ensure a sufficient fetal growth and survival in this environment as a consequence of either a potential restriction before a fast growth from foetuses genotype $R$ or a lower functionality of placenta.

As the placenta is an interface receiving signals from both mother and foetus and a platform for maternal-fetal interaction, we analyzed fetal-placental to evaluate the fetal genotype effects on prenatal survival analysis compared gene expression with an embryo transfer system using the two inbred lines (A/A and $R / R)$. The fact that no differences were observed in gene expression in fetal placentas at both Day 14 and Day 24 of gestation was surprising, considering that embryonic genotype had influence on the prenatal survival. Although, in terms of prenatal survival, the vast majority of the studies indicated a strong maternal uterine genotype effect (inbred strains (Fekete, 1947; Baunack et al., 1986), genetically selected lines (Brumby, 1960; Moore et al., 1970a,b; Aitken et 
al., 1977; Al-Murrani and Roberts, 1978; Moler et al., 1981), or cross-nursing and sib analysis studies (Cox et al., 1959; El-Oksh et al., 1967)). Our findings indicate that the influence of embryo and maternal genotypes on rabbit prenatal survival and growth seem to change over gestation.

In conclusion, embryonic genotype seems to influence prenatal survival, but additionally, at last term of gestation maternal genotype can affect embryonic mortality. Moreover, at early gestation (Day 14), embryonic genotype has an effect on fetal weight, while both embryonic and maternal genotype affected placental weights at Day 24 and 30, respectively. These findings highlight the need to consider both maternal and embryonic genetic effects in the neonatal survival over the course of pregnancy.

\section{REFERENCES}

Aitken RJ, Bowman P, Gauld I. 1977. The effect of synchronous and asynchronous egg transfer on foetal weight in mice selected for large and small body size. J Embryol exp Morph 37 59-64.

Al-Murrani WK, Roberts C. 1978 Maternal effects on body weight in mice selected for large and small size. Genet Res Camb 32 295-302.

Argente MJ, Santacreu MA, Climent A, Blasco A. 2003. Relationships between uterine and fetal traits in rabbits selected on uterine capacity. J Anim Sci 81 1265-1273.

Ashworth CJ, Haley CS, Aitken RP, Wilmut I. 1990. Embryo survival and conceptus growth after reciprocal embryo transfer between Chinese Meishan and Landrace x Large White gilts. J Reprod Fertil 90 595-603.

Barkley MS, Fitzgerald R. 1990. Influence of embryonic and maternal genotype on gestational events in the mouse. J Reprod Fertil 89 285-291. 
Baunack E, Wieding B, Gartner K. 1986. Prenatal survival of reciprocal Fl hybrids in inbred mice caused both by embryonic factors and genotype of foster mother. Zuchthygene 21 115-120.

Besenfelder U, Brem G. 1993. Laparoscopic embryo transfer in rabbits. J Reprod Fertil 99 53-56.

Biensen NJ, Wilson ME, Ford SP. 1998. The impact of either a Meishan or Yokshire uterus on Meishan or Yokshire fetal and placental development to days 70, 90 and 110 of gestation. J Anim Sci 76 2169-2176.

Blasco A, Bidanel JP, Bolet G, Haley C, Santacreu MA. 1993. The genetics of prenatal survival of pigs and rabbits: a review. Livest Prod Sci 37 1-21.

Brien FD. 1986. A review of the genetic and physiological relationships between growth and reproduction in mammals. Anim Breed Abtr 54 975-997.

Brumby PJ. 1960. The influence of the maternal environment on growth in mice. Heredity 14 1-18.

Buffat C, Mondon F, Rigourd V,Boubred F, Besiières B, Fayol L, Feverstein JM, Gamerre M, Jammes H, Rebourcet R, Miralles F, Courbières B, Basire A, DignatGeorges F, Carbonne B, Simeoni U, Vaiman D. 2007. A hierarchical analysis of transcriptome alterations in intrauterine growth restriction (IUGR) reveals common pathophysiological pathways in mammals. J Pathol 213 337-346.

Chaddha V, Viero S, Huppertz B, Kingdom J. 2004. Developmental biology of the placenta and the origins of placental insufficiency. Semin Fetal Neonatal Med 9 357-369.

Cox DF, Legates JE, Cockerham CC. 1959. Maternal influence on body weight. J Anim Sci 18 519-527.

El-Oksh HA, Sutherland TM, Williams JS. 1967. Prenatal and postnatal maternal influence on growth in mice. Genetics, Princeton 57 79-94. 
Ernst CA, Rhees BK, Miao CH, Atchley WR. 2000. Effect of long-term selection for early postnatal growth rate on survival and prenatal development of transferred mouse embryos. J Reprod Fertil 118 205-210.

Estany J, Baselga M, Blasco A, Camacho J. 1989. Mixed model methodology for the estimation of genetic response to selection in litter size in rabbit. Livest Prod Sci 21 67-76.

Estany J, Camacho J, Baselga M, Blasco A. 1992. Selection response of growth rate in rabbits for meat production. Genet Sel Evol 24 527-537.

Fekete E. 1947. Differences in the effect of uterine environment upon development in the dba and C57 black strains of mice. Ana Ree 98 409-415.

Foxcroft GR, Dixon WT, Novak S, Putman CT, Town SC, Vinsky MDA. 2006. The biological basis for prenatal programming of postnatal performance in pigs. J Anim Sci 84 105-112.

Freking BA, Leymaster KA, Vallet JL, Christenson RK. 2007. Number of fetuses and conceptus growth throughout gestation in lines of pigs selected for ovulation rate or uterine capacity. J Anim Sci 85 2093-2103.

Gu T, Zhu MJ, Schroyen M, Qu L, Nettleton D, Kuhar D, Lunney JK, Ross JW, Zhao SH, Tuggle CK. 2014. Endometrial gene expression profiling in pregnant Meishan and Yorkshire pigs on day 12 of gestation. BMC Genomics 15156.

Holt M, Vaguen O, Farstad W. 2004. Components of litter size in mice after 110 generations of selection. Reproduction 127 587-592.

Kaminski MA, Ford SP, Youngs CR, Conley AJ. 1996. Lack of effect of sex on pig embryonic development in vivo. J Reprod Fertil 106 107-1 10.

Laborda P, Mocé ML, Blasco A, Santacreu MA. 2012. Selection for ovulation rate in rabbits: genetic parameters and correlated response on survival rates. J Anim Sci 90 439-446. 
Llobat L, Marco-Jiménez F, Peñaranda DS, Thieme R, Navarrete A, Vicente JS. 2012. mRNA expression in rabbit blastocyst and endometrial tissue of candidate genes involved in gestational losses. Reprod Dom Anim 47 281-287.

Lockhart DJ, Dong H, Byrne MC, Follettie MT, Gallo MV, Chee MS, Mittmann M, Wang C, Kobayasi M, Horton H. 1996. Expression monitoring by hybridization to high-density oligonucleotide array. Nat Biotechnology 14 1675-1680.

Mocé ML, Santacreu MA, Climent A, Blasco A. 2004a. The effect of divergent selection for uterine capacity on fetal and placental development at term in rabbits: Maternal and embryonic genetic effects. J Anim Sci 82 1046-1052.

Mocé ML, Santacreu MA, Climent A, Blasco A. 2004b. The effect of divergent selection for uterine capacity on prenatal survival in rabbits: Maternal and embryonic genetic effects. J Anim Sci 82 68-73.

Moler TL, Donahue SE, Anderson GB, Bradford GE. 1981. Effects of maternal and embryonic genotype on prenatal survival in two selected mouse lines. Anim Sci 51 300-303.

Moore RW, Eisen EJ, Ulberg LC. 1970a. Genetic and uterine effects on survival in mice selected for body weight. J Reprod Fert 23 271-275.

Moore RW, Eisen EJ, Ulberg LC. 1970b. Prenatal and postnatal maternal influences on growth in mice selected forbody weight. Genetics, Princeton 64 $59-68$.

Pomp D, Cowley DE, Eisen EJ, Atchley WR, Hawkins-Brown D. 1989. Donor and recipient genotype and heterosis effects on survival and prenatal growth of transferred mouse embryos. J Reprod Fert 86 493-500.

Salilew-Wondim D, Tesfaye D, Hossain M, Held E, Rings F, Tholen E, Looft C, Cinar U, Schellander K, Hoelker M. 2013. Aberrant placenta gene expression pattern in bovine pregnancies established after transfer of cloned or in vitro produced embryos. Physiol Genomics 45 28-46.

SenthamaraiKannan P, Sartor MA, O'Connor KT, Neumann JC, Klyza JP, 
Succop PA, Wagner BD, Karyala S, Medvedovic M, Menon AG. 2011. Identification of maternally regulated fetal gene networks in the placenta with a novel embryo transfer system in mice. Physiol Genomics 43 317-324.

Vicente JS, Llobat L, Jimenez-Trigos E, Lavara R, Marco-Jimenez F. 2013. Effect of embryonic and maternal genotype on embryo and foetal survival in rabbit. Reprod Dom Anim 48 402-406.

Vicente JS, Llobat L, Viudes-de-Castro MP, Lavara R, Baselga M, MarcoJiménez F. 2012. Gestational losses in a rabbit line selected for growth rate. Theriogenology 77 81-88.

Weltzien FA, Pasqualini C, Vernier P, Dufour S. 2005. A quantitative real-time RT-PCr assay for European eel tyrosine hydroxylase. Gen Comp Endocrinol 15 134-142.

Wilson ME, Biensen NJ, Youngs CR, Ford SP. 1998. Development of Meishan and Yokshire littermate conceptuses in either a Meishan or Yokshire uterine environment to day 90 of gestation and to term. Biol Reprod $\mathbf{5 8} 905-910$.

Whitehead CL, Walker SP, YE S, Mendis S, Kaitu'U-Lino TJ, Lappas M, Tong S. 2013. Placental Specific mRNA in the Maternal Circulation Are Globally Dysregulated in Pregnancies Complicated by Fetal Growth Restriction. JCEM 98 E429-E436.

Yllera MM, Alexandre-Pires GM, Cifuentes JM. 2003. Placenta: Regularization of neovascularization. Microvascularization pattern of the rabbit term placenta. Microsc Res Tech 60 38-45.

Youngs CR, Christenson LK, Ford SP. 1994. Investigations into the control of litter size in swine: III. A reciprocal embryo transfer study of early conceptus development. J Anim Sci 72 725-731.

Zhou QY, Fang MD, Huang TH, Li CC, YU M, Zhao SH. 2009. Detection of differentially expressed genes between Erhulian and Large White placentas on day 75 and 90 of gestation. BMC Genomics 103. 



\section{Study of ovulation failures in a rabbit line selected for growth}

\section{rate}

C. Naturil-Alfonsoa, R. Lavaraa, P. Millánb, P.G. Rebollarc, J.S. Vicentea, F. MarcoJiméneza

alnstitute of Science and Animal Technology, Laboratorio de Biotecnología de la Reproducción, Universidad Politécnica de Valencia, Valencia, 46022

bDepartamento de Fisiología Animal, Facultad de Veterinaria, Universidad Complutense of Madrid, Ciudad Universitaria s/n, 28040 Madrid, Spain

cDepartamento de Producción Agraria, Escuela Técnica Superior de Ingenieros Agrónomos, Universidad Politécnica de Madrid, Ciudad Universitaria s/n, 28040 Madrid, Spain.

World Rabbit Science. 2016 24:47-53.

This work was supported by the Spanish Research Project AGL2011- 30170-C02-01 (CICYT). Carmen Naturil was supported by a research grant from the Education Ministry of the Valencian Regional Government (programme VALi+d. ACIF / 2013 / 296). 
. 


\section{ABSTRACT}

Selection for growth rate is negatively related with reproductive fitness. The aim of this work was to analyse the causes of fertility failure in rabbit does selected for growth rate and characterized for reproductive deficiencies (line R). In the experiment, 82 does were divided in two groups: naturally mated (NM) and artificially inseminated (AI) to relate LH concentration with ovulation induction and pregnancy rate by laparoscopic determination. Additionally, in 38 of these females ovulation rate and metabolites determination (leptin, NEFA, BOHB and glucose) were analysed and perirenal fat thickness measurement and live body weight (LBW) were determined. The results showed that all ovulated does (both NM and Al) presented higher concentration of LH than non-ovulated females. In addition, non-ovulated females showed high levels of leptin and BOHB, as well as LBW. Females from line $R$ have an inherit reduced fertility due to ovulation failure as a consequence of a reduction in LH release, which could be explained by a heavier body weight and higher leptin concentrations. 



\section{INTRODUCTION}

In rabbit, as in other species, selection for growth traits shows negative correlated responses in reproductive performance (Mgheni and Christensen, 1985; Gómez et al., 1999; Ragab and Baselga, 2010). Nevertheless, estimates of genetic correlation in rabbits between the litter size and growth traits are low and contradictory, as the magnitude and the sign of the correlations could depend on the correlated reproductive trait, as well as the population or strain under study. In previous studies comparing paternal and maternal lines, differences have been reported in ovulation frequency, ovulation rate, gestational losses and consequently in litter size (Vicente et al., 2003; 2012; 2013). Recent estimations of the effects of inbreeding on litter size exclude it as the factor explaining the differences observed between the paternal and maternal lines (Gadsby et al., 1983). The selection process for the rabbit paternal line showed a response per generation of $0.5 \mathrm{~g} /$ day in daily weight gain from weaning to slaughter and $118 \%$ overweight at end of fattening period, specifically $139 \%$ in adult females compared with the maternal line (Gómez et al., 1999). Reproductive troubles described in these rabbit parental lines have been reported in many obesity models (Pasquali and Casimirri, 1993; Tortoriello et al., 2004). Body fat excess has shown a negative effect on pulsatile luteinizing hormone (LH) release from the pituitary (Cano ef al., 2008; Uenoyama et al., 2008), early embryonic gene expression (Picone et al., 2011), disturbances in pre-implantation development (Sjoblom et al., 2005), reduction in implantation and fetal development (Hendrickse et al., 1985; Haggarty, 2002) and reduced birth weights of the kits (Montoudis et al., 1999; Cordier et al., 2013). 
Rabbit is a reflexively ovulating species in which sensory and neuroendocrine stimuli act together to induce a LH preovulatory surge and determine ovulatory response (Dufy-Barbe et al., 1973; Fisher et al., 2012). Genital somatosensory stimulation is necessary to activate GnRH neurons and generate a preovulatory LH surge form the pituitary gland (Jones et al., 1976; Dal Bosco et al., 2011). Currently, lines selected for growth rate are characterized by a high growth rate and adult live weight. Nevertheless, a reduced reproductive performance (mice, Brien et al., 1984; Eisen et al., 1973; pig, Chen et al., 2003; Kuhlers and Jungst, 1992; and rabbits, Estany et al., 1992; Gómez et al., 1998; Vicente et al., 2012), and also elevated disease incidence, despite having higher body condition score (Sánchez et al., 2012) have been described.

In this study we evaluated whether the ovulation induction failures previously observed in a rabbit line selected for growth rate could be due to an inadequate neuroendocrine reflex in the hypothalamic-pituitary system.

\section{MATERIALS AND METHODS}

All chemicals in this study were purchased from Sigma-Aldrich Química S.A. (Madrid, Spain) unless stated otherwise.

\section{Ethical Statement}

The experiment was performed in accordance with the principles of animal care published by Spanish Royal Decree 53/2013 (BOE 2013). The animal studies were approved by the Committee of Ethics and animal Welfare of the Universidad Politécnica de Valencia. Researchers involved in the work with the animals held an animal experimentation licence iissued by the Spanish authorities. 


\section{Animals}

A total of 82 females from a synthetic rabbit line selected for growth rate between weaning and slaughter time (9th wk of life) for 35 generations (line $R$, Instituto de Ciencia y Tecnología Animal, Spain, Estany et al., 1992) were housed individually, at 12 weeks of age, with free access to water, under a 16 hours light/8 hours dark photoperiod unless stated below. Animals were fed a commercial rabbit diet (on dry matter (DM) basis: $17.5 \%$ crude protein, $3.5 \%$ ether extract, $16.7 \%$ crude fiber, $2938 \mathrm{kcal}$ of digestible energy (DE) per $\mathrm{kg}$ of DM).

\section{Determination of LH concentration and ovulation relationship}

At the age of 5 months, receptivity of does was determined observing the vulvar color and turgescence, considering those with red/purple and swollen vulva receptive. Receptive does were divided into 2 groups: naturally mated (NM, $n=50$ ) or artificially inseminated (Al, $n=32)$. All NM females mated successfully. Artificial insemination was performed with $0.5 \mathrm{~mL}$ of fresh heterospermic pool selected with motility criteria (more than $70 \%$ of motility rate and less than $15 \%$ of abnormal sperm) and diluted 1:5 with tris-citric-glucose diluent (Viudes-de-Castro and Vicente, 1997). Immediately after insemination, ovulation was induced by an intramuscular injection of $1 \mu \mathrm{g}$ of Busereline Acetate (Suprefact, Hoechst Marion Roussel, S.A., Madrid, Spain).

According to the literature, $\mathrm{LH}$ determinations were performed taking as average point 90 minutes after Al/NM (based on Meunier et al., 1983; Muelas et al., 2008; Quintela et al., 2004). Blood samples were taken from the marginal ear vein, placed in EDTA-coated tubes and immediately centrifuged at $2500 \mathrm{rpm}$ for 10 minutes and stored at $-20^{\circ} \mathrm{C}$ until analysed. 
Ovulation and pregnancy were confirmed by laparoscopy after 12 days for both groups. Females were anaesthetised by an intramuscular injection of 16 mg xylazine (Rompun; Bayern AG, Leverkusen, Germany), followed by an intravenous injection of ketamine hydrochloride at the rate of $25 \mathrm{mg} / \mathrm{kg}$ body weight (Imalgene 1000; Merial S.A, Lyon, France) to keep does under anaesthesia during laparoscopy. The absence of corpora lutea was indicative that the ovulation process did not occur (ovulation failure).

Additionally, in 38 of these does ( $N M=28$ and $A l=10)$ at laparoscopy, the number of corpora lutea was recorded per female (assumed as ovulation rate, OR). For the NM group (15 ovulated and 13 non-ovulated), serum blood samples were taken just after NM or Al to analyse for leptin, non-sterified fat acids (NEFA), beta-hydroxybutyrate (BOHB) and glucose, and the body condition was determinated.

\section{Hormone and metabolites analysis}

Plasma LH concentrations were determined by a homologous ELISA method validated for rabbits and previously described (Rebollar et al., 2012; Dall'Aglio et al., 2013). Briefly, the RbLH antigen (provided by Dr A.F. Parlow; Pituitary Hormones and Antisera Center, National Hormone and Peptide Program, National Institute of Diabetes and Digestive and Kidney Diseases, HarborUniversity of California Los Angeles Medical Center, CA, USA) was biotinylated with EZ-Link® Biotinylation Kit (Pierce Biotechnology, Rockford, IL, USA) according to the manufacturer's instructions. EIA microtiter plates (Corning Inc, Corning, NY, USA) were coated with secondary antibody anti-guinea pig IgG (Southern Biotech, Birmingham, AL, USA). Then, the anti RbLH were added into wells. Duplicates of $50 \mu \mathrm{L}$ of appropriate standards (range 0.781 to $400 \mathrm{ng} / \mathrm{ml}$ ), 
buffer (zero standard), plasma samples and assay controls were pipetted into respective wells. Biotinylated-RbLH (EZ-Link® Biotinylation Kit), Streptavidinperoxidase (Sigma Chemical, St Louis, MO, USA) and the substrate $\left(3,3^{\prime}, 5^{\prime}, 5^{\prime}-\right.$ tetramethylbenzidine, 1-Step Ultra TMB-ELISA; Pierce Biotechnology, Rockford, IL, USA) were added across the entire plate. The lowest concentration of RbLH that could be distinguished from zero concentration was $0.78 \mathrm{ng} / \mathrm{mL}$. The intraassay coefficient of variation of the analysis was $5.2 \%$. Inter-assay precision calculated by the nine replicate measurements of coefficient of variation for pools of high and low concentrations was 3.1 and 6.84, respectively. The accuracy of the ElA, determined by measuring the recovery rates of known amounts of $\mathrm{RbLH}(5,25$, and $125 \mathrm{ng} / \mathrm{ml})$ added to different plasma samples, was $90.0 \%, 96.0 \%$, and $88.6 \%$ for low, medium and high values, respectively.

Leptin was analyzed by Multispecies Leptin assay (RIA, XL-85K) (Milipore Corporation, Billerica, MA, USA), according to the manufacturer's guidelines. Intra- and inter-assay CV were $9.1 \%$ and $9.3 \%$, respectively. NEFA's were determined using the NEFA C ACS-ACOD assay method (Wako Chemicals GmbH, Neuss, Germany). BOHB was determined as an increase in absorbance at $340 \mathrm{~nm}$ owing to the production of $\mathrm{NADH}$, at slightly alkaline $\mathrm{pH}$ in the presence of $\mathrm{BOHB}$ dehydrogenase. Sample blanks were included and the method involved oxamic acid in the media to inhibit lactate dehydrogenase, as proposed by Harano et al. (1985). Glucose was determined according to standard procedures (Siemens Diagnostics ${ }^{\circledR}$ Clinical Methods for ADVIA 1650). Analyses of NEFA, BOHB and glucose were performed using an auto-analyser, ADVIA $1650^{\circledR}$ Chemistry System 8Siemens Medical Solutions, Tarrytown, NY, USA); 
in all instances, the intra- and inter-assay CV was below $2 \%$ and $4 \%$, respectively.

\section{Body condition}

The perirenal fat thickness (PFT) of does was measured by ultrasound to asses body condition at the moment of the NM or Al, as described by Pascual et al. (2000). Briefly, images were obtained with an ultrasound unit (Justvision 200 "SAS-320A" real-time sound machine, Toshiba), equipped with an electronic micro-convex transducer of multi-frequency (5.0, 6.0 and 7.0 -MHz; PVG-681S). PFT measures were indirectly obtained using the software of the ultrasound unit. At the moment of the PFT measurement does were also weighted.

\section{Statistical analysis}

To compare gestation rate between groups including the fecundation type with 2 levels (Al or NM) as a fixed factor, a general linear model (GLM) was performed, using the probit link function. Binomial data for fertility were assigned a value of 1 if pregnancy was positive. Failure to $\mathrm{Al} / \mathrm{NM}$ resulted in a score of 0.

The GLM procedure was performed to determine differences in LH concentration related to ovulation and pregnancy, including as fixed effects the type of fecundation (NM or Al), ovulation or pregnancy (positive or negative) and their interaction. Ovulation rate was analyzed with a GLM including the type of fecundation (NM or Al) as fixed factors.

All metabolites, body weight and perirenal fat thickness were analyzed by a GLM including ovulated or non-ovulated naturally mated females as fixed factors. Correlations between these traits were analyzed. 
Differences of $p<0.05$ were considered significant. Data are shown as means \pm standard error means (S.E.M). All analysis were performed with Statgraphics Plus

\section{1.}

\section{RESULTS}

The $34.3 \%$ of the NM females were pregnant, while for Al females the pregnancy rate was $66.7 \%$.

All the Al females ovulated successfully. Four groups were determined: (i) Al: ovulation \& gestation; (ii) Al: ovulation \& non-gestation; (iii) NM: ovulation \& gestation; (iv) NM: non-ovulation \& non-gestation; No NM female showed ovulation \& non-gestation. The average plasma LH levels in ovulated and nonovulated females are shown in Figure 2.1.

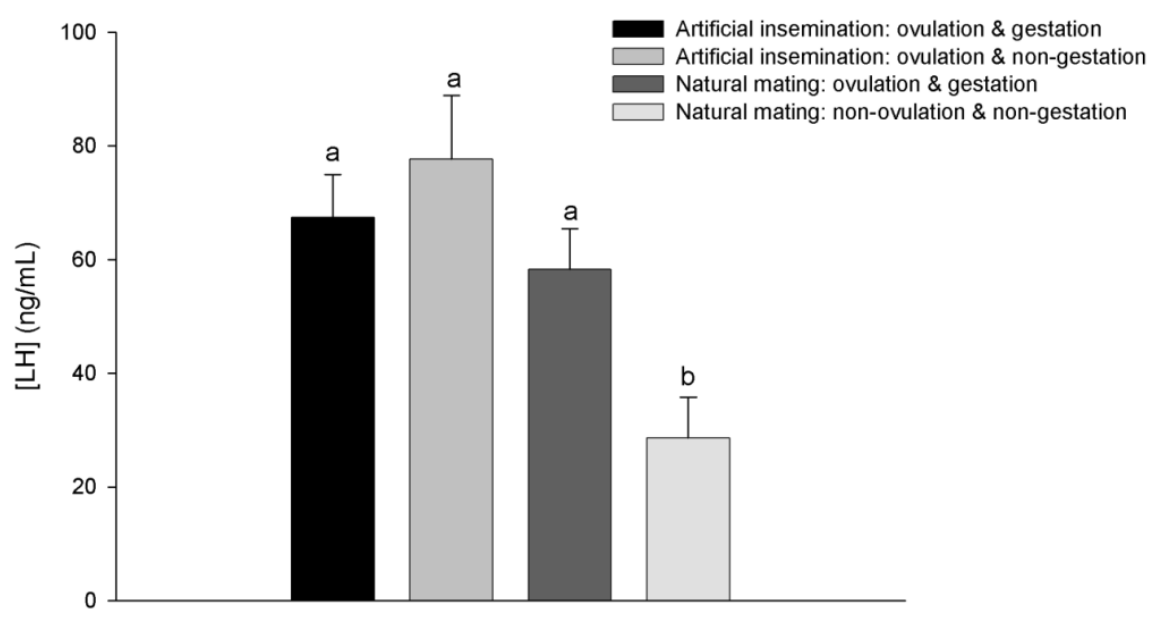

Figure 2.1. Mean LH concentration 90 minutes after natural mating or artificial insemination females, related to ovulation and gestation diagnosis. Bars show the mean value \pm SEM of the females involved in each group. Bars with different letters are significantly different $(p<0.05)$.

The relation between $\mathrm{LH}$ concentration and ovulation showed that $\mathrm{LH}$ is higher in ovulated females (NM or Al) than in non-ovulated females. Additionally, nonsignificant differences in LH concentration between NM and Al pregnant 
females were observed (58.34 \pm 7.11 and $67.39 \pm 7.57$, respectively). The number of $\mathrm{CL}$ for ovulated females (OR) was significantly decreased in the NM group compared to the Al group (12.50 \pm 0.64 vs. $14.90 \pm 0.83$, respectively; $p<0.05)$.

Table 2.1 summarizes metabolite results between non-ovulated and ovulated NM females. Serum leptin levels in non-ovulated NM females were significantly high compared to ovulated ones $(0.60 \pm 0.09$ vs. $0.40 \pm 0.04 \mathrm{ng} / \mathrm{mL}$, respectively; $\mathrm{p}<0.05)$. Similarily, plasma BOHB levels in non-ovulated NM females were significantly higher than in ovulated does $10.10 \pm 0.01$ vs. $0.01 \pm 0.01 \mathrm{mM}$, respectively; $p<0.05)$. In contrast, the presence/absence of ovulation did not affect plasma glucose and NEFA (9.00 $\pm 0.72 \mathrm{vs.} 8.20 \pm 0.34 \mathrm{mM}$ for glucose and $192.00 \pm 43.80$ vs. $131.00 \pm 20.90 \mu \mathrm{ekv} / \mathrm{L}$, for NEFA, respectively).

Table 2.1. Metablite concentration of naturally mated females if ovulated or nonovulated after mating.

\begin{tabular}{|c|c|c|c|c|}
\hline Females & \multicolumn{4}{|c|}{ Metabolite } \\
\hline Type & Glucose (mM) & BOHB (mM) & NEFAs ( $\mu \mathrm{ekv} / \mathrm{L})$ & Leptins $(\mathrm{ng} / \mathrm{mL})$ \\
\hline $\mathrm{OV}(\mathrm{N}=15)$ & $8.20 \pm 0.34$ & $0.01 \pm 0.01 a$ & $131.00 \pm 20.90$ & $0.40 \pm 0.04^{a}$ \\
\hline $\mathrm{N}-\mathrm{OV}(\mathrm{N}=13)$ & $9.00 \pm 0.72$ & $0.10 \pm 0.01^{b}$ & $192.00 \pm 43.80$ & $0.60 \pm 0.09 b$ \\
\hline
\end{tabular}

OV: ovulated females; N-OV: non-ovulated females; N: number of females. Data are presented as least square means \pm standard error. Different superscripts represent a difference $(P<0.05)$.

Finally, non-ovulated females were heavier than ovulated females (6230 $\pm 232 \mathrm{~g}$ vs. $5389 \pm 111 \mathrm{~g}$, respectively; $\mathrm{p}<0.05$; Table 2.2). Although a positive correlation (0.34) was found between body weight and BOHB levels, no other correlations between body weight and metabolites were found. Nevertheless, no significant differences were observed for perirenal fat thickness (9.70 \pm 0.32 vs. $9.10 \pm 0.15$ $\mathrm{mm}$, for non-ovulated and ovulated females, respectively, Table 2.1). 
Table 2.2. Body conditions of naturally mated females if ovulated or non-ovulated after mating.

\begin{tabular}{|c|c|c|}
\hline Females & \multicolumn{2}{|c|}{ Body condition } \\
\hline Type & Body weight (g) & PTF (mm) \\
\hline OV (N=15) & $5389 \pm 111 \mathrm{a}$ & $9.10 \pm 0.15$ \\
\hline $\mathrm{N}-\mathrm{OV}(\mathrm{N}=13)$ & $6230 \pm 232^{\mathrm{b}}$ & $9.70 \pm 0.32$ \\
\hline
\end{tabular}

OV: ovulated females; N-OV: non-ovulated females; $\mathrm{N}$ : number of females; PTF: Perirrenal Fat Thickness. Data are presented as least square means \pm standard error. Different superscripts represent a difference $(P<0.05)$.

\section{DISCUSSION}

The female line used in this study (paternal line or Line R) has previously been extensively characterized for reproductive deficiencies (Vicente et al., 2012). Specifically, our previous findings indicate that these females showed a lower ovulation rate when compared with a control line $(70 \%$ vs. $86 \%$ for line $R$ and control line, respectively), with higher failures in ovulation induction (30\%) (Vicente et al., 2012). These results of ovulation failure seem to be similar to those observed in this work, with a $32 \%$ reduction in fertility when females are naturally mated.

Our results showed that $\mathrm{LH}$ concentration seems to be related with the ovulation success, as all ovulated females presented higher levels of LH concentration, but additionally NM females (with lower release of LH, although not significant) presented an ovulation rate lower than Al (with higher release of LH). When line $R$ does are induced to ovulate with GnRH analogues, no significant failures are observed in ovulation frequency: between $95-100 \%$ of Al females treated with a GnRH analogue ovulated (Viudes-de-Castro et al., 1995; Mehaisen et al., 2004; Vicente et al., 2003:2012). Additionally, the GnRH analogue injected after $\mathrm{Al}$ could increase systemic $\mathrm{LH}$ blood concentrations and could promote more LH receptors in the follicles than GnRH naturally 
secreted after natural mating (Pieper et al., 1981). Therefore, these results suggest that problems due to $\mathrm{LH}$ secretion or to $\mathrm{LH}$ follicular receptors can be discarded. Moreover, Balasubramanian et al. (2012) showed that lower LH levels impair ovulation process, causing a lower number of fresh corpora lutea, as we detected in this work.

In natural mating, a nervous stimulus is needed for $\mathrm{LH}$ release and triggering ovulation in rabbits. The coitus provokes the release of norepineprhine in the hypothalamus, followed by the delivery of GnRH into the portal vessels, which in turn triggers the release of pituitary LH into the peripheral blood stream (Bakker and Baum, 2000). The absence of any of these events decrease LH concentration and consequently, affects the ovulation process in rabbit (Rebollar et al., 2012). Hence, ovulation deficiencies seem to be due to reduced LH concentrations, because a failure in the nervous stimuli to the hypothalamus or an inadequate neuroendocrine reflex in the hypothalamicpituitary system to trigger the adequate $\mathrm{GnRH}$ response caused the decrease in mean LH concentration and the lower ovulation and, consequently, the lower global pregnancy rates observed in this work.

GnRH neurons are modulated by several hypothalamic neuropeptides related to energy metabolism and steroid hormones, metabolic hormones and metabolites, such as leptin, insulin, glucose, etc. The results from this study provide evidences that female rabbits that are selected for growth rate have significant changes in their neuroendocrine system, observing lower levels of LH and higher levels of leptin and BOHB in these females. This may indicate that leptin could be interfering with ovulation. When we analyzed metabolites and hormones related to lipid metabolism, we observed an increase in leptin and 
$\mathrm{BOHB}$ in non-ovulated females. On the one hand, leptin effects directly act on kisspeptin neurons, a peptide which directly signals GnRH neurons to control pulsatile GnRH release, and thus stimulates LH secretion (Quennel et al., 2011). On the other hand, it has been suggested that an increase in serum leptin concentration may have a role in the steroidogenesis of pre- and postovulatory follicles: leptin suppresses estradiol production and interferes with the development of dominant follicles and oocyte maturation (Moschas et al., 2002). Thus, the absence of ovulation observed in non-ovulated mated females may be related to leptin concentrations, in accordance which other authors that showed how an elevation in leptin levels is likely to cause a reduction in secretion by decreasing LH production by the pituitary, also preventing the release of the oocytes from the preovulatory follicles (Duggal et al., 2000; Brecchia et al., 2006; Balasubramanian et al., 2012). Our results also showed an increase in $\mathrm{BOHB}$ in non-ovulated females. Increased concentrations of $\mathrm{BOHB}$ and NEFA have been related with negative effects on reproductive performance (Opsina et al., 2010; Kiani, 2012).

Additionally, high weight and diet could suppress reproductive functions by acting directly on the pituitary or the ovary (Balasubramanian et al., 2012). Excessive lipid storage in mice was shown to induce ovarian dysfunction disorders with advanced follicular atresia, apoptosis and defective steroidogenesis (Seke et al., 2012). In this study, non-ovulated females showed to be heavier than ovulated females. Cardinali et al. (2008) showed that rabbit does with optimal body condition reach higher fertility rates and show better LH secretion than rabbit does with either excess or deficit of fat depots. 
In conclusion, rabbits selected for growth rate showed a decrease in fertility when naturally mated, which seemed to be due to an ovulation failure. This absence of ovulation comes as a consequence of a reduction in $\mathrm{LH}$ concentrations, which could be due the heaviest body weight of these females, which may involve alterations in hormones and metabolites, such as leptin and $\mathrm{BOHB}$. Further studies in reproductive effectiveness and its relation with overweight should be carried out to determine these factors' relationship with metabolism.

\section{REFERENCES}

Balasubramanian P, Jagannathan L, Subramanian $M$, Gilbreath ET, MohanKumar PS, MohanKumar SMJ. 2012. High fat diet affects reproductive functions in female diet-induced obese and dietary resistant rats. J Neurondocrinol 24 748-755.

Bakker J, Baum MJ. 2000. Neuroendocrine regulation of $\mathrm{GnRH}$ release in induced ovulators. Front Neuroendocrinol 21 220-262.

Brecchia G, Bonanno A, Galeati G, Federici C, Maranesi M, Gobbetti A, Zerani M, Boiti C. 2006. Hormonal and metabolic adaptation to fasting: Effects on the hypothalamic-pituitary-ovarian axis and reproductive performance of rabbit does. Dom Anim Endocrinol 31 105-122.

Brien FD, Sharp GL, Hill WG, Robertson A. 1984. Effects of selection on growth, body composition and food intake in mice. II. Correlated responses in reproduction. Genet Res 44 73-85.

Cano P, Jiménez-Ortega V, Larrad A, Reyes Tosco CF, Cardinali DP, Esquifina Al. 2008. Effect of a high-fat diet on 24-h pattern of circulating levels of prolactin, luteinising hormone, testosterone, corticosterone, thyroid-stimulating hormone and glucose, and pineal melatonin content, in rats. Endocrine 33118 125. 
Cardinali R, Dal Bosco A, Bonanno A, Di Grioli A, Rebollar PG, Lorenzo PL, Castellini C. 2008. Connection between body condition score, chemical characteristics of body and reproductive traits of rabbit does. Livest Sci 116209 215.

Chen P, Baas TJ, Mabry JW, Koehler KJ. 2003. Genetic correlations between lean growth and litter traits in U.S. Yorkshire, Duroc, Hampshire, and Landrace pigs. Anim Sci J 81 1700-1705.

Cordier AG, Léveille P, Dupont C, Tarrade A, Picone O, Larcher T, Dahirel M, Poumerol E, Mandon-Pepin B, Lévy R, Chavatte-Palmer P. 2013. Dietary lipid and cholesterol induce ovarian dysfunction and abnormal $\mathrm{LH}$ response to stimulation in rabbits. Plos one 8 e63101.

Dal Bosco A, Rebollar PG, Boii C, Zerani M, Castellini C. 2011. Ovulation induction in rabbits does: Current knowledge and perspectives. Anim Reprod Sci 129 106-117.

Dall'Aglio C, Millán P, Maranesi M, Rebollar PG, Brecchia G, Zerani M, Gobbetti A, Gonzalez-Mariscal G, Boiti C. 2013. Expression of the cannabionoid receptor type 1 in the pituitary of rabbits and its role in the control of LH secretion. Dom Anim Endocrinol 45 171-179.

Dufy-Barbe L, Franchimot P, Faure GMA. 1973. Time courses of the LH and FSH release after mating in the female rabbit. Endocrinology 92 1318-1321.

Duggal PS, Van Der Hoek KH, Milner CR, Ryan NK, Amstrong DT, Magoffin DA, Norman RJ. 2000. The in vivo and in vitro effects of exogenous leptin on ovulation in the rat. Endocrinology 141 1971-1976.

Eisen EJ, Hanrahan JP, Legates JE. 1973. Effects of population size and selection intensity on correlated responses to selection for postweaning gain in mice. Genetics 74 157-170.

Estany J, Camacho J, Baselga M, Blasco A. 1992. Selection response of growth rate in rabbits for meat production. Genet Sel Evol 24 527-537. 
Fisher B, Chavatte-Palmer P, Viebahn C, Navarrete-Santos A, Duranthon V. 2012. Rabbit as a reproductive model for human health. Reproduction 144 1-10.

Gadsby JE, Keyes PL, Bill CH. 1983. Control of corpus luteum function in the pregnant rabbit: role of estrogen and lack of a direct luteotropic role of the placenta. Endocrinology 119 2255-2262.

Gomez EA, Rafel O, Ramon J. 1998. Genetic relationships between growth and litter size traits at first parity in a specialized dam line. Proc. 6th W.C.G.A.L.P., Vol. XXV, 552-555.

Gómez AE, Baselga M, Rafel O, García ML, Ramón J. 1999. Selection, diffusion and performances of six Spanish lines of meat rabbit. Cahiers Options Méditerranéennes 41 147-152.

Haggarty P. 2002. Placental regulation of fatty acid delivery and its effect on fetal growth- a review. Placenta 23 S28-38.

Harano YM, Ohtsuki MI, Kojima H, Harada M, Okanishi T, Kashiwagi A, Ochi Y, Uno S, Shigeta Y. 1985. Direct automated assay method for serum or urine levels of ketone bodies. Clin Chim Acta 151 177-183.

Hendrickse W, Stammers JP, Hull D. 1985. The transfer of free fatty acids across the human placenta. Br J Obstet Gynaecol 92 945-952.

Jones EF, Bain JB, Odell WD. 1976. Postcoital luteinizing hormone release in male and female rabbits as determine by radioimmunoassay. Fertil Steril 27848 852.

Kiani. 2012. Temporal changes in plasma concentration of leptin, IGF-I, insulin and metabolites under extended fasting and re-feeding conditions in growing lambs. Int J Endocrinol and metabol 11 34-40.

Kuhlers DL, Jungst SB. 1992. Correlated responses in reproductive and carcass traits to selection for 200-day weight in Duroc swine. J Anim Sci 70 2707-2713.

Mgheni M, Christensen K. 1985. Selection experiment on growth and litter size in rabbits: II. Two-way selection response for body weight at 112 days. Acta Agric Scand 95 278-286. 
Mehaisen GMK, Vicente JS, Lavara R. 2004. In vivo embryo recovery rate by laparoscopic technique from rabbit does selected for growth rate. Reprod Dom Anim 43 147-151.

Meunier M, Hulot F, Poirier JC, Torres S. 1983. A comparison of ovulatory gonadotropic surge in two rabbit strains: no evidence for a relationship between LH or FSH surge and factors of prolificacy. Reprod Nutr Dévelop 23 709-715.

Montoudis A, Simoneau L, Brisette L, Forest JC, Savard R, Lafond J. 1999. Impact of cholesterol enriched diet on maternal and fetal plasma lipids and fetal deposition in pregnant rabbits. Life Sci 64 2439-2450.

Moschas S, Chan JL, Mantzoros CS. 2002. Leptin and reproduction: a review. Fertil Steril 77 433-444.

Muelas R, Cano P, García ML, Esquifino A, Argente MJ. 2008. Influence of FSH, LH and prolactin on the components of litter size in rabbit does. $9^{\text {th }}$ World Rabbit Congress, 10-13 June, 2008. Verone, Italy.

Opsina PA, Nydam DV, Stokol T, Overton TR. 2010. Associations of elevated nonesterified fatty acids and $\beta$-hydroxybutyrate concentrations with early lactation reproductive performance and milk production in transition airy cattle in the northeaster United States. J Dairy Sci 93 1596-1603.

Pascual JJ, Castella F, Cervera C, Blas E, Fernández-Carmona J. 2000. The use of ultrasound measurement of perirenal fat thickness to estimate changes in body condition of young female rabbits. Anim Sci 70 435-442.

Pasquali R, Casimirri F. 1993. The impact of obesity in hyperandrogenism and polycystic ovary syndrome in premenopausal women. Clin Edocrinol 39 1-16.

Pieper DR, Richards JS, Marshall JC. 1981. Ovarian gonadotropin-releasing hormone $(\mathrm{GnRH})$ receptors: characterization, distribution and induction by GnRH. Endocrinology $1081148-1155$.

Picone O, Laigre P, Fortun-Lamothe L, Archilla C, Peynot N, Ponter AA, Berthelot V, Cordier AG, Duranthon V, Chavatte-Palmer P. 2011. Hyperlipidic 
hypercholesterolemic diet in prepubertal rabbits affects gene expression in the embryo, restricts fetal growth and increases offspring susceptibility to obesity. Theriogenology 75 287-299.

Quennell JH, Howell CS, Roa J, Augustine RA, Grattan DR, Anderson GM. 2011. Leptin deficiency and diet-induced obesity reduce hypothalamic kisspeptin expression in mice. Endocrinology 152 1541-1550.

Quintela LA, Peña Al, Vega MD, Gullón J, Prieto MC, Barrio M, Becerra JJ, Maseda F, Herradón PG. 2004. Ovulation induction in rabbit does submitted to artificial insemination by adding busereline to the seminal dose. Reprod Nutr Dev 44 1-10.

Ragab M. Baselga M. 2010. Inbreeding effect on reproductive traits in four maternal lines of rabbits. Proc: 9th World Congress on Genetics Applied to Livestock Production, 1-6 August, 2010. Leipzig, Germany. p. ID083

Rebollar PG, Dal Bosco A, Millán P, Cardinali R, Brecchia G, Sylla L, Lorenzo PL, Castellini C. 2012. Ovulating induction in rabbit does: The pituitary and ovarian responses. Theriogenology 77 292-298.

Sánchez JP, de la Fuente LF, Rosell JM. 2012. Health and body condition of lactating females on rabbit farms. J Anim Sci 90 2353-2361.

Seke H, Nowicki M, Kosacka J, Schroder T, Kloting N, Bluher M, Kallendrusch S, Spanel-Borowski K. 2012. Leptin-deficient (ob/ob) mouse ovaries show fatty degeneration, enhanced apoptosis and decreased expression of steroifogenic acute regulatory enzyme. Int J Obes (Lond) 36 1047-1053.

Sjoblom C, Roberts CT, Wikland M, Roberston SA. 2005. GranulocyteMacrophage colony-stimulating factor alleviates adverse consequences embryo culture on fetal growth trajectory and placental morphogenesis. Endocrinology 146 2142-2153.

Tortoriello DV, McMinn J, Chua SC. 2004. Dietary-induced obesity and hypotalamic infertility in female DBA/2J mice. Endocrinology 45 1238-1247. 
Uenoyama Y, Tsukamura H, Kinoshita M, Yamada S, Iwata K, Pheng V, Sajapitak S, Sakakibara M, Ohtaki T, Matsumoto H, Maeda KI. 2008. Oestrogendependent stimulation of luteinizing hormone release by galanin-like peptide in female rats. J Neuroendocrinol 20 626-631.

Vicente JS, Viudes-de-Catro MP, García ML, Baselga M. 2003. Effect of rabbit line in a cryopreservation program by vitrification. Reprod Nutr Develop 43 147153.

Vicente JS, Llobat L, Viudes-de-Castro MP, Lavara R, Baselga M, MarcoJiménez F. 2012. Gestational losses in a rabbit line selected for growth rate. Theriogenology 77 81-88.

Vicente JS, Llobat L, Jiménez-Trigos E, Lavara R, Marco-Jiménez F. 2013. Effect of embryonic and maternal gneotype on embryo and foetal survival in rabbit. Reprod Dom Anim 48 402-406.

Viudes-de-Castro MP, Garcia-Ximénez F, Vicente JS. 1995. Embryo recovery from eliminating does of three rabbit strain for an embryo bank. Invest. Agr Prod Sanid Anim 10 145-152.

Viudes-de-Castro MP, Vicente JS. 1997. Effect of sperm count on the fertility and prolificity traits of meat rabbits. Anim Reprod Sci 46 313-31. 



\section{CHAPTER THREE}

Feed restriction regime in a rabbit line selected for growth rate alters oocyte maturation manifested by alteration in msy2 gene expression

C. Naturil-Alfonso', J.S. Vicente', F. Marco-Jiménez'

'Institute of Science and Animal Technology, Laboratorio de Biotecnología de la Reproducción, Universidad Politécnica de Valencia, Camino de Vera s/n, 46022 Valencia, Spain

This work was supported by the Spanish Research Project AGL2014- 53405-C2-1-P (CICYT). Carmen Naturil was supported by a research grant from the Education Ministry of the Valencian Regional Government (programme VALi+d. ACIF/2013/296). 



\section{ABSTRACT}

Rabbit selected for growth rate may have nutritional needs which may not be met with the traditional management in productive farms. In fact, females with high growth rate have shown severe reproductive problems. The aim of this study was to analyse if fed-to-appetite nutritional strategy would improve the reproductive performance of these females. Rabbit females were categorized in two groups: (i) does with ad libitum access to feed or (ii) restricted feeding (130g/day). After one month in these experimental conditions and three reproductive cycles, two experiments were conducted: (i) a microarray analysis of hypothalamus-hypophysis of both groups of females was performed to analyse the possible origin of ovulation failures; (ii) the quality of the oocytes produced was assessed by gene expression analysis of some candidate genes. No differences were found in the microarray analysis, while only differences in MSY2 expression were found. MSY2 was over-expressed in oocytes from females fed ad libitum if compared with oocytes from restricted does. MSY2 is one of the most abundant proteins in the oocyte and has proven to be a key regulator of maternal RNA transcription and translation. Therefore, any changes in this gene could explain the drop in reproductive performance in females with higher growth potential. 



\section{INTRODUCTION}

Different strategies have been proposed to improve reproductive performance in farm animals, such as feed intake during rearing and before mating/insemination (Rommers et al., 2004). A restrictive diet during rearing is used to control body condition and prevent the effects of overfattening on fertility and fetal losses. On the other hand, an ad libitum diet provides better sexual development in terms of receptivity, ovulation rate, blastocyst size and implantation rate (Ashworth et al., 1999a,b; Rommers et al., 2004).

Different feeding strategies have been shown to affect female reproduction through alterations in GnRH secretion, inhibition or delay of $\mathrm{LH}$ surge and fluctuations of estradiol-17ß and progesterone concentrations (Boland et al., 2001; Kiyma et al., 2004; Ferguson et al., 2003). Likewise, they have been shown to affect ovarian follicle development (Alexander et al., 2007) and follicular characteristics (Armstrong et al., 2001), ovulation (Yan et al., 2008), oocyte morphology and developmental potential (McEvoy et al., 1995; O'Callaghan et al., 2000; Ferguson et al., 2003), embryo development (García-García et al., 2011) and fertility rates (Brecchia et al., 2006), resulting in reduced oocyte quality in terms of in vitro fertilization rates and embryonic development (Papadopoulos et al., 2001).

In this sense, previous studies in line $\mathrm{R}$ have determined that females had the lowest ovulation frequency of about $30 \%$ compared to maternal line females (Vicente et al., 2012; Naturil-Alfonso et al., 2016). These ovulation failures were related to reduced LH plasma concentrations when females did not ovulate naturally, while in all line $\mathrm{R}$ does induced to ovulate with $\mathrm{GnRH}$ analogues 
ovulation occurred in 95-100\% (Viudes-de-Castro et al., 1995; Vicente et al., 2003; 2012; Naturil-Alfonso et al., 2016). It has been shown that fasting modifies the responses of the anterior pituitary gland to GnRH activity, leading to a reduced synthesis of LH by pituitary cells (Brecchia et al., 2006; Ferguson et al., 2003). Moreover, Labreque et al. (2014) reported that the suppression of LH pulses may have an impact either on follicle development or on the oocyte quality. And a similar problem in oocyte and/or embryo quality of line R females submitted to different feeding regimens was recently suggested (Naturil-Alfonso et al., 2015).

Hence, the aim of this study was to analyse whether different nutritional regimes applied after rearing prior to mating could modulate on the origin of ovulation process and the quality of the oocytes. The hypothesis was that these females are selected for growth rate and the nutritional regimen may not be enough to cope with their needs during reproduction, causing a long-term nutrient deficiency which leads to the subsequent reproductive problems.

\section{MATERIAL AND METHODS}

All chemicals used in this study were purchased from Sigma-Aldrich Química S.A. (Madrid, Spain) unless stated otherwise.

\section{Ethical Statement}

The experiment was performed in accordance with the principles of animal care published by Spanish Royal Decree 53/2013 (BOE 2013). The animal studies were approved by the Committee of Ethics and animal Welfare of the Universidad Politécnica de Valencia (procedure 2015/vsc/PEA/00061). 
Researchers involved in work with the animals held an animal experimentation license issued by the Spanish authorities.

\section{Animals}

A total of 22 females from a synthetic line selected for growth rate between weaning and slaughter time (9th wk of life) for 36 generations (line R, Instituto de Ciencia y Tecnología Animal, Estany et al., 1992) were used. Does were housed individually at 12 wk of age, with free access to water, under a $16 \mathrm{~h}$ light/8 h dark photoperiod, unless otherwise stated.

At four months of age, females from a line selected for growth rate were divided into two experimental groups: feeding ad libitum or restricted (provided daily with $130 \mathrm{~g} /$ day to comply with energy requirements for maintenance: 340 kJ day-1 kg-1 LW0.75; Xiccato and Trocino, 2010). Rabbits were fed a commercial rabbit diet (on dry matter basis: $17.5 \%$ crude protein, $3.5 \%$ ether extract, $16.7 \%$ crude fibre, $2938 \mathrm{kcal} / \mathrm{kg}$ ). After one month under these experimental conditions, 22 receptive females (10 ad libitum and 12 restricted) were employed.

\section{Experiment 1. Hypothalamus-pituitary microarray}

From these females, hypothalamus-pituitary was recovered. For this, females were euthanized by intravenous injection of $200 \mathrm{mg} / \mathrm{kg}$ of pentobarbital sodium (Dolethal, Vétoquinol, Madrid, Spain). Samples from each female were stored for RNA expression analysis at $-80^{\circ} \mathrm{C}$.

At the moment of sacrify, body weight and body composition of does were determined. The perirenal fat thickness (PFT) of does was measured by ultrasound to evaluate body condition, as described by Pascual et al. (2000). 
Briefly, images were obtained with the portable colour Doppler ultrasound device mentioned previously. PFT measures were indirectly obtained using the software of the ultrasound unit.

\subsection{RNA extraction}

PolyA RNA was extracted from hypothalamus-pituitary. Total RNA was isolated from 22 samples of the whole hypothalamus-hypophysis for each female using traditional phenol/chloroform extraction by sonication in the Trizol reagent (Invitrogen). Then, RNA was purified by RNA Clean-up columns (Nucleospin, Madrid, Spain) and the concentration, quality and integrity of RNA were evaluated by Bioanalyzer 2100 (Agilent Technologies).

\subsection{Microarray analysis}

For the two-colour microarray analysis, four biological replicates were used for ad libitum hypothalamus-pituitary, including two dye swaps to compensate dye-bias. For restricted hypothalamus-pituitary, four biological replicates were used, including one dye-swap.

Total RNA (100 ng) was amplified using QuickAmp Labelling Kit (Agilent Technologies, Madrid, Spain), following the manufacturer's instructions. The complementary RNA (CRNA) generated was purified and labelled with Cyanine 3 dye (Cy3) and Cyanine 5 dye (Cy5). Excess dye was removed with the QIAquick PCR purification kit (Quiagen Iberia S.L., Madrid, Spain) and dye incorporation and concentration were determined using the microarray setting on the Nanodrop 1000.

Equal amounts of Cy3 and Cy5 labelled samples (825 ng) were mixed with 10X Blocking Agent and Fragmentation Buffer, then $55 \mu \mathrm{L}$ of the mixture were 
hybridised into the Rabbit 44x oligonucleotide array G2519F (Agilent Technologies, Madrid, Spain). After 17 hours at $65^{\circ} \mathrm{C}$, hybridized slides were washed and scanned using the Agilent DNA Microarray Scanner G2565B (Agilent Technologies, Madrid, Spain). The resulting images were processed using Feature Extraction v.10 Software (Agilent Technologies, Madrid, Spain with default parameters. Normalization with the locally weighted linear regression (LOWESS) algorithm and identification of differentially expressed transcripts was achieved using the Limma package in R (www.r-project.org). P-values were adjusted for multiple testing using Benjamini and Hochberg false discovery rate (FDR) and differences of $\mathrm{p}<0.05$ were considered significant.

\subsection{Real-time PCR}

To validate the microarray results obtained, seven genes (LRP2: LDL-related protein; EMP1: Epithelial membrane protein 1; ANXA3: Annexin A3; RBP4: Retinol-binding protein 4; CITED1: Cbp/p300-interacting transactivator, with Glu/Asp-rich carboxy-terminal domain; TNFAIP6: Tumour necrosis factor alphainduced protein 6; EGFLAM: EGF-like fibronectin type III and laminin G domains) were carried out in twenty-two independent pool samples (microarray samples plus additional pools). To prevent DNA contamination, one deoxyribonuclease treatment step (gDNA Wipeout Buffer, Qiagen Iberia S.L, Madrid, Spain) was performed from total RNA (1000 ng). Afterwards, reverse transcription was carried out using the qScriptTM cDNA Synthesis kit (Quanta BioSciences Inc., Gaithersburg, USA) according to the manufacturer's instructions. Real-time PCR (RT-PCR) reactions were conducted in an Applied Biosystems 7500 (Applied Biosystems, Foster City, CA). Every PCR was performed with $5 \mu \mathrm{L}$ of 1:20 diluted CDNA template (except for TNFAIP6 and EGFLAM which was 1:10 diluted 
cDNA), 250nM of forward and reverse primers (Table 3.1) and 10 $\mathrm{\mu L}$ of PowerSYBR Green PCR Master Mix (Fermentas GMBH, Madrid, Spain) in a final volume of $20 \mu \mathrm{L}$. The PCR protocol included an initial step of $50^{\circ} \mathrm{C}$ (2 min), followed by $95^{\circ} \mathrm{C}(10 \mathrm{~min})$ and 40 cycles of $951 \mathrm{C}(15 \mathrm{sec})$ and $60^{\circ} \mathrm{C}(1 \mathrm{~min})$. After RT-PCR, a melting curve analysis was performed by slowly increasing the temperature from $65^{\circ} \mathrm{C}$ to $95^{\circ} \mathrm{C}$, with continuous registration of changes in fluorescent emission intensity. Serial dilutions of cDNA pool made from several samples were run in triplicate to assess PCR efficiency and decide which dilution to use for unknown samples. Target and reference genes in unknown samples were run in duplicate. Non-template controls (cDNA was replaced by water) for each primer pair were run in all plates. A $\Delta \Delta \mathrm{Ct}$ method adjusted for PCR efficiency was used, employing the geometric average of H2AFZ $(\mathrm{H} 2 \mathrm{~A}$ histone family member Z) and GAPDH (glyceraldehyde-3-phosphate dehydrogenase) as housekeeping normalization factor (Weltzein et al., 2005). Relative expression of cDNA pool from various samples was used as the calibrator to normalize all samples within one RT-PCR run or between several runs. The products of RT-PCR were confirmed by ethidium bromide-stained $2 \%$ agarose gel electrophoresis in 1x Bionic buffer (Sigma-Aldrich Química S.S, Alcobendas, Madrid, Spain).

\section{Experiment 2. Oocyte gene expression}

\subsection{Oocyte recovery}

Twelve females (7 ad libitum and 5 restricted) were induced to ovulate by an intramuscular injection of $1 \mathrm{\mu g}$ of Busereline Acetate (Suprefact, Hoechst Marion Rousell, S.A., Madrid, Spain). Sixteen hours post-ovulation, females were euthanized as described above, and reproductive tracts were recovered. 
Oocytes were recovered by perfusion of each oviduct with $10 \mathrm{~mL}$ of prewarmed DPBS supplemented with $0.2 \%$ of BSA. The OR (number of $\mathrm{CL}$ ) and ovulation recovery rate (calculated as the number of oocytes recovered in each female from the total of $\mathrm{CL}$ in both ovaries) were recorded for each female. A pool of oocytes of each female was stored for RNA expression analysis at $-80^{\circ} \mathrm{C}$.

\subsection{RNA extraction}

As the amount of RNA present in a single oocyte is rather limited, for each experimental group (ad libitum and restricted derived oocytes) six independent pools consisting of 35 oocytes were produced.

A pool of oocytes was homogenized after two freezing steps in Liquid Nitrogen. Afterwards, RNA isolation was performed using Dynabeads® mRNA Purification Kit (Invitrogen) according to the manufacturer's instructions. Finally, RNA amplification, DNAse step and purification was performed using MasterPure ${ }^{\mathrm{TM}}$ RNA Purification Kit, according to manufacturer's instructions (Epicentre, Barcelona, Spain).

RNA isolated from oocytes was reverse transcribed into cDNA using SuperScript III Reverse Transcriptase (Invitrogen S.A., Barcelona, Spain) in a total volume of $20 \mu \mathrm{L}$, according to the manufacturer's insturctions. The RT reaction was carried out at $25^{\circ} \mathrm{C}$ for $5 \mathrm{~min}$ and $50{ }^{\circ} \mathrm{C}$ for $60 \mathrm{~min}$, followed by an inactivation step at $75^{\circ} \mathrm{C}$ for $15 \mathrm{~min}$. 


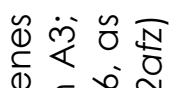

ब.

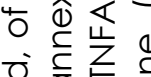

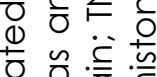

远

흘

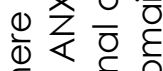

$\frac{1}{3}=\frac{\bar{c}}{\mathrm{E}} \mathrm{O}$

0.

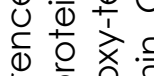

产

@

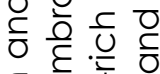

을 월ㄹ

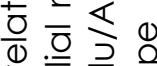

$\frac{\overline{0}}{0} \frac{0}{0} \frac{0}{2}$

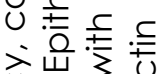

Uू口

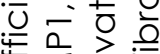

0

过

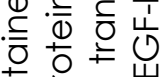

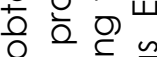

응

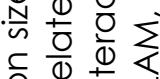

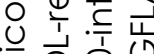

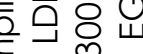

응 용

ฝั 용

है응

일

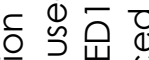

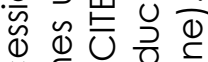

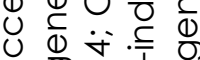

0 .

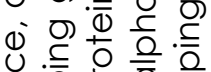

흐웡 ब

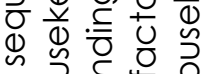

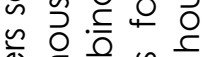

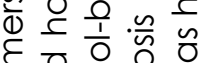

旅

$\dot{\dot{m}} \mathrm{O}$

m心

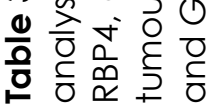

\begin{tabular}{|c|c|c|c|c|c|c|c|c|c|}
\hline$\approx$ & ơ & $\underset{\alpha}{\alpha}$ & $\stackrel{\alpha}{\alpha} \underset{0}{0}$ & $\underset{\alpha}{\alpha}{ }_{0}^{\alpha}$ & $\begin{array}{l}\text { aे } \\
\text { o }\end{array}$ & $\begin{array}{l}a \\
\text { oे }\end{array}$ & $\begin{array}{l}\text { aे } \\
\text { o }\end{array}$ & $\begin{array}{l}\text { a } \\
\text { o }\end{array}$ & $\begin{array}{l}\alpha \\
\alpha \\
0\end{array}$ \\
\hline 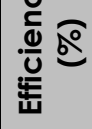 & $\begin{array}{l}\stackrel{\sim}{+} \\
\underset{\sigma}{\alpha}\end{array}$ & $\begin{array}{l}\infty \\
\infty \\
\stackrel{\rho}{\alpha} \\
\alpha\end{array}$ & $\begin{array}{l}\bar{\alpha} \\
\text { à }\end{array}$ & $\stackrel{\text { on }}{0}$ & $\stackrel{\circ}{\circ}$ & $\begin{array}{l}\stackrel{\circ}{\infty} \\
\stackrel{\infty}{\circ}\end{array}$ & 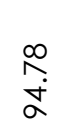 & $\stackrel{\circ}{\circ}$ & $\stackrel{\circ}{\circ}$ \\
\hline 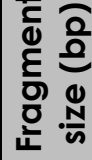 & $\stackrel{\mathscr{L}}{\infty}$ & $\underset{\Xi}{J}$ & $\stackrel{\tilde{m}}{\underline{n}}$ & $\stackrel{\bigcirc}{=}$ & $\stackrel{\hat{0}}{0}$ & $\stackrel{\widetilde{N}}{\simeq}$ & ָి & $\alpha$ & 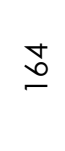 \\
\hline 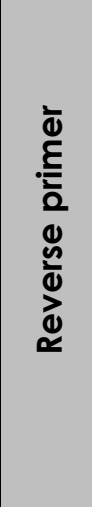 & $\begin{array}{l}U \\
u \\
0 \\
0 \\
0 \\
0 \\
0 \\
0 \\
U \\
0 \\
0 \\
0 \\
0 \\
0 \\
0 \\
0\end{array}$ & $\begin{array}{l}0 \\
\mathbb{8} \\
0 \\
8 \\
0 \\
0 \\
0 \\
8 \\
0 \\
E \\
0 \\
0 \\
0 \\
0 \\
8\end{array}$ & 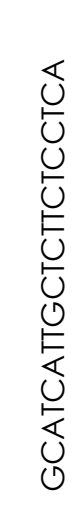 & 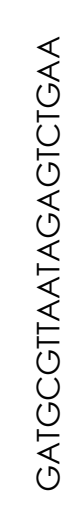 & 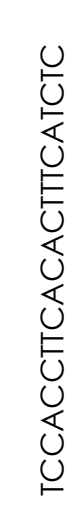 & $\begin{array}{l}0 \\
\mathbb{8} \\
0 \\
0 \\
0 \\
0 \\
0 \\
0 \\
0 \\
\mathbb{8} \\
0 \\
0 \\
0 \\
0 \\
0 \\
0 \\
1\end{array}$ & $\begin{array}{l}0 \\
0 \\
0 \\
0 \\
0 \\
\mathbb{8} \\
8 \\
0 \\
0 \\
0 \\
0 \\
0 \\
0 \\
0 \\
0 \\
\mathbb{8}\end{array}$ & 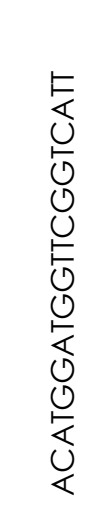 & 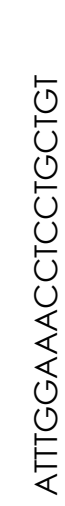 \\
\hline 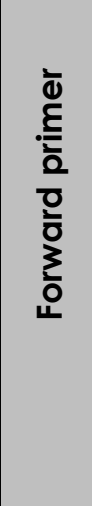 & 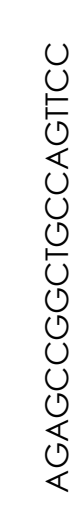 & $\begin{array}{l}0 \\
0 \\
0 \\
0 \\
0 \\
0 \\
0 \\
0 \\
0 \\
0 \\
0 \\
0 \\
0 \\
0\end{array}$ & 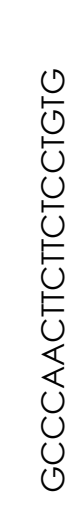 & $\begin{array}{l}0 \\
0 \\
0 \\
0 \\
0 \\
0 \\
0 \\
0 \\
0 \\
0 \\
0 \\
0 \\
0 \\
0 \\
8\end{array}$ & 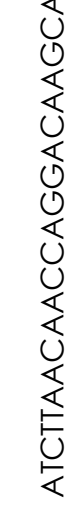 & $\begin{array}{l}0 \\
0 \\
0 \\
0 \\
0 \\
0 \\
0 \\
0 \\
0 \\
0 \\
0 \\
0 \\
0 \\
0 \\
0 \\
0\end{array}$ & 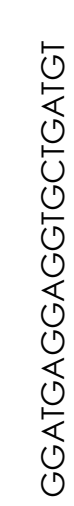 & 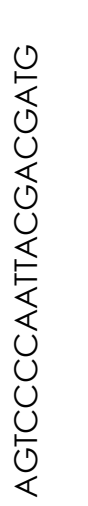 & $\begin{array}{l}\mathbb{8} \\
0 \\
0 \\
0 \\
0 \\
0 \\
\mathbb{0} \\
0 \\
0 \\
0 \\
0 \\
0 \\
0 \\
0 \\
0\end{array}$ \\
\hline 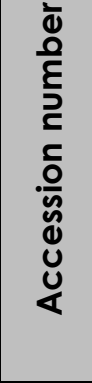 & 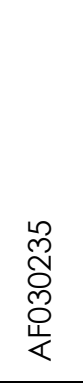 & $\begin{array}{l}\overline{\bar{\alpha}} \\
\stackrel{\sim}{\exists}\end{array}$ & 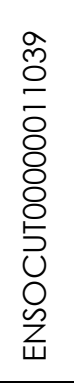 & 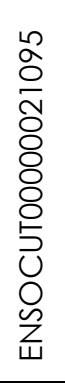 & 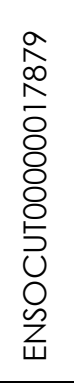 & 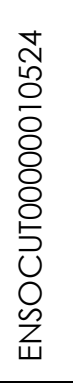 & 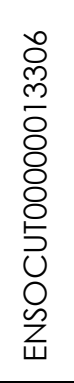 & 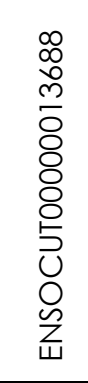 & 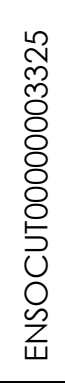 \\
\hline 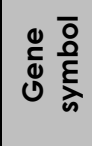 & 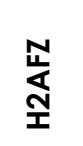 & 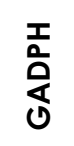 & $\stackrel{3}{3}$ & $\sum_{u}^{u}$ & $\begin{array}{l}\stackrel{0}{x} \\
\underset{x}{x} \\
\frac{x}{4}\end{array}$ & 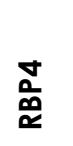 & 岂 & 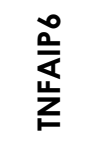 & 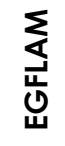 \\
\hline
\end{tabular}




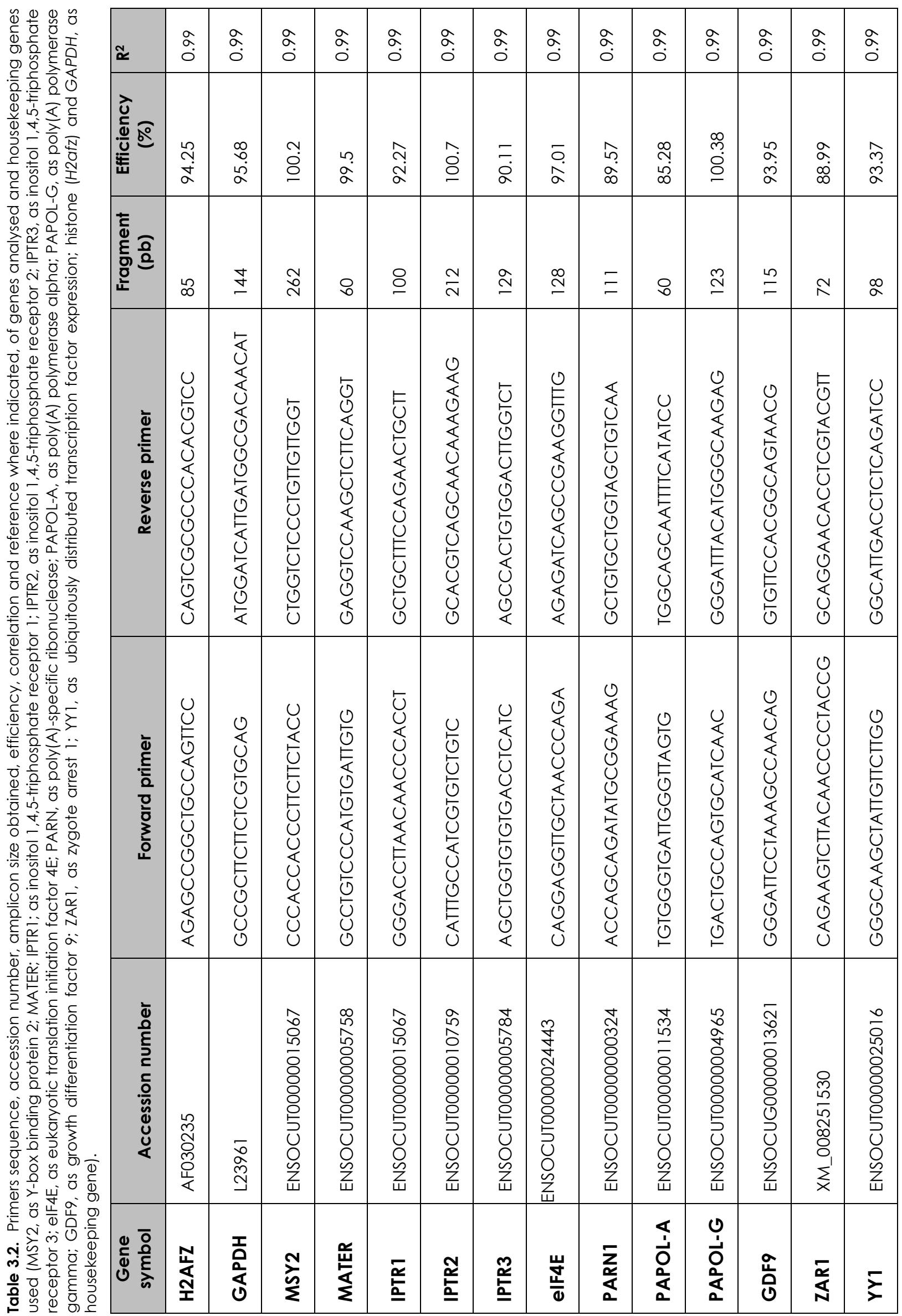




\subsection{Primer design}

Two genes, Histone (H2afz) and Glyceraldehyde-3-phosphate dehydrogenase (GAPDH) were selected as reference genes in the quantitative RT-PCR, in accordance with Llobat et al. (2011). Furthermore, gene specific primers were designed exon-exon and assayed to evaluate MSY2: Y-box binding protein 2; MATER1, IPTR1: inositol 1,4,5-triphosphate receptor 1; IPTR2: inositol 1,4,5triphosphate receptor 2; IPTR3: inositol 1,4,5-triphosphate receptor 3; elF4E: eukaryotic translation initiation factor 4E; PARN: poly(A)-specific ribonuclease; PAPOL-A: poly(A) polymerase alpha; PAPOL-G: poly(A) polymerase gamma; GDF9: growth differentiation factor 9; ZAR1: zygote arrest 1; YY1: ubiquitously distributed transcription factor expression (Table 3.2). To avoid DNA contamination, DNA and RNA samples were run to check possible amplification.

\subsection{Real-time $P C R$}

The mRNA expression was analysed by real-time PCR in an Applied Biosystems 7500 (Applied Biosystems, Foster City, CA) with $5 \mu \mathrm{L}$ of 1:10 diluted cDNA template, and as previously described.

\section{Statistical analysis}

Data were analysed using the SPSS software package, version 16.0 (SPSS Inc, Chicago Illinois, USA 2002). Results are reported as least mean squares \pm SEM. Means were considered statistically different at $\mathrm{P}<0.05$.

Ovulation rate and oocyte recovery rate were analysed by a GLM including feeding regimen (ad libitum or restricted) as fixed factor. For mRNA expression, data on relative mRNA abundance among different groups in each 
comparison were analysed after data normalization by Napierian logarithm transformation and evaluated using GLM.

\section{RESULTS}

\section{Experiment 1. Hypothalamus-pituitary microarray}

Ad libitum females showed to be heavier than restricted ones (5899.09 \pm 133.187 kg vs. $5329.00 \pm 139.687 \mathrm{~kg}$, for ad libitum and restricted females, respectively). AS expected, the same tendency was reported for PFT $(9.63 \pm$ $0.231 \mathrm{~mm}$ vs. $8.89 \pm 0.243 \mathrm{~mm}$, for ad libitum and restricted females, respectively). Limma analysis after normalization did not reveal any significant changes in gene expression. A total of 7 genes represented on the microarray (LPR2, EMP1, ANXA3, RBP4, CITED1, TNFAIP6, EGFLAM) were selected and tested using RT-PCR. According to the microarray results, no significant differences were observed between groups (Figure 3.1).

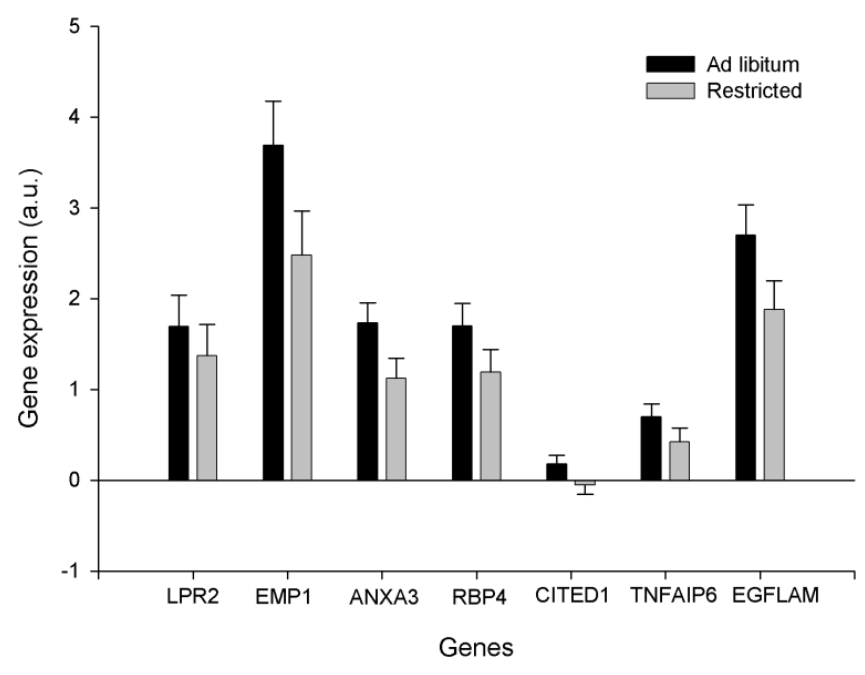

Figure 3.1. Relative expression of LDL-related protein (LRP2), Epithelial membrane protein 1 (EMP1), Annexin A3; RBP4: retinol-binding protein4 (ANXA3), Cbp/p300interacting transactivator, with Glu/Asp-rich carboxy-terminal domain (CITED 1), Tumour necrosis factor alpha-induced protein 6 (TNFAIP6) and EGF-like fibronectin type III and laminin $G$ domains (EGFLAM) for validation of hypothalamus-hypophysis microarray. Relative abundance values are shown in arbitrary units (a.u.), expressed by the mean value \pm standard error means. 


\section{Experiment 2. Oocyte gene expression}

\subsection{Oocyte recovery}

No differences were found either in ovulation rate or in recovery rate. Ovulation rate was $12.2 \pm 1.60$ and $13.2 \pm 1.13$ for ad libitum and restricted donor females, respectively. The oocyte recovery rate was $0.87 \pm 0.043$ vs. $0.92 \pm 0.024$, for ad libitum and restricted donor females respectively.

\subsection{Oocyte gene expression}

Differences in relative transcript abundance between groups are shown in Figure 3.2. These genes were selected because they represent essential stages of oocyte maturation and development, such as oocyte activation, mRNA transcription and oocyte-embryo transition. From the total of 12 genes analysed, only MSY2 gene expression was shown to be different between both groups of oocytes. Oocytes from females fed ad libitum showed a higher MSY2 gene expression levels than oocytes from restricted females.

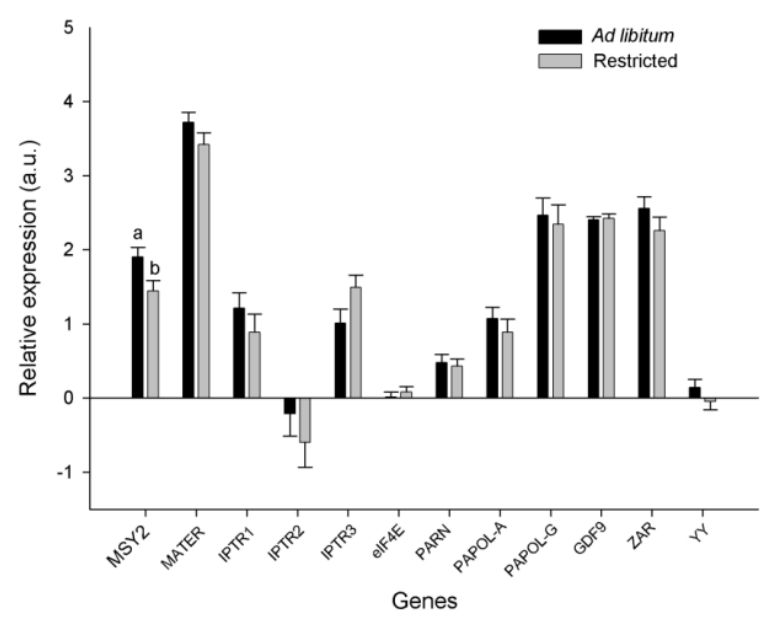

Figure 3.2. Relative expression of Y-box binding protein 2 (MSY2), MATER, Inositol 1,4,5-triphosphate receptor 1 (IPTR1), Inositol 1,4,5-triphosphate receptor 2 (IPTR2), Inositol 1,4,5-triphosphate receptor 3 (IPTR3), Eukaryotic translation initiation factor 4E (elF4E), Poly(A)-specific ribonuclease (PARN), Poly(A) polymerase alpha (PAPOL-A), Poly(A) polymerase gamma (PAPOL-G), Growth differentiation factor 9 (GDF9), Zygote arrest 1 (ZAR1), Ubiquitously distributed transcription factor expression (YY1). Relative abundance values are shown in arbitrary units (a.U.), expressed by the mean value \pm standard error means. 


\section{DISCUSSION}

Previous studies have shown that rabbit females selected for growth rate have severe reproductive problems, which start with ovulation failures (Vicente et al., 2012; Naturil-Alfonso et al., 2016a). These females have been shown to weigh $26 \%$ more than maternal or other lines/breeds not used in meat production (De la Fuente and Rosell, 2012). Our hypothesis was that the restricted nutritional regime in the last pubertal period prior to onset of the reproductive period is not enough to cope with the needs during reproduction of these females with higher growth rate and conversion index, causing a long-term deficiency which leads to the subsequent reproductive problems. Indeed, females fed ad libitum have shown reduced gestational losses and higher fetal growth than restricted does (Naturil-Alfonso et al., 2016b).

Balasubramanian et al. (2012) showed that body weight and diet could suppress reproductive function by acting on the hypophysis or the ovary, causing a reduction in ovulatory function. Diet and food ingestion modify different metabolic hormones, such as leptin, insulin and neuropeptide $Y$, which can eventually alter the reproductive function. Specifically, leptin controls GnRH functionally through its ability to activate kisspeptin-positive neurons (Smith et al., 2006). Kisspeptin has been shown to stimulate GnRH neurons in several species (Martin et al., 2008) which finally affects the reproductive capacity in animals by disturbing LH and FSH secretion, and hence estradiol and testosterone release.

A previous study showed that natural mated females presented higher failures in ovulation rate due to a decreased LH release (Naturil-Alfonso et al., 2016a). These authors hypothesized the existence of an insufficient neuroendocrine 
reflex in the hypothalamus-hypophysis system to trigger adequate GnRH secretion. However, our results revealed no differences in the neuroendocrine system, as no differences in gene expression were detected between the hypothalamus-hypophysis system from ad libitum and restricted females. The absence of differences leads us to conclude that ovulation failures may be caused by peripheral mechanisms rather than central mechanisms, such as failure in the nervous stimuli to the hypothalamus-hypophysis system.

On the other hand, nutritional support has been identified as one of the relevant factors affecting embryo developmental competence of oocytes and embryos (Moussa et al., 2015). Indeed, following our hypothesis, maternal nutrition is essential to provide the follicular cells with enough energy to grow and complete developmental programmes (Moussa et al., 2105). Nevertheless, despite the evidence, discrepancies are still found in the literature regarding the impact of nutrition on oocyte and embryonic quality.

In rabbit, Mahmoud et al. (2006) reported the same recovery rate of oocytes from control and $60 \%$ of control fed females during one or two months. In contrast, Dadoud et al. (2012) reported higher oocyte recovery rate from control fed females (150 g/day) than those fed $70 \%$ of control diet. Our results here showed no differences in either ovulation rate or recovery rate between oocytes from ad libitum and restricted females, in accordance with those published by Mahmoud et al. (2006).

Likewise, Dadoud et al. (2012) observed reduced oocyte quality in restricted females with lower gene expression of GDF-9 in oocytes from restricted females from the high range of quality classification. Moreover, García-García et al. 
(2011) reported a drop in embryo development and speed development in embryos from $72 \mathrm{~h}$ post-conception fasted females, while no differences in blastocyst gene expression were detected.

In this study, we observed no significant effects between both groups of oocytes in most of the chosen candidate genes related to oocyte activation, mRNA translation and transcription and oocyte-embryo transition. The only gene from the group selected that proved to be differentially expressed between both groups of oocytes was MSY2. MSY2 is a Y-box protein involved in relevant processes of oocyte maturation and growth such as stability, transcription and translation regulation of maternal mRNAs. Thus, it is responsible for alterations in the pattern of protein synthesis during oocyte maturation (GU et al., 1998; Yu et al., 2001). MSY2 relevance became evident with the finding that this protein is one of the most abundant oocyte proteins identified to date, accounting for roughly $2 \%$ of the total protein in the fully grown oocyte (Yu et al., 2001). The results of this study revealed a decreased MSY2 gene expression in oocytes derived from restricted females when compared with oocytes from females fed ad libitum. A reduced MSY2 expression in the oocyte has been identified with reduction in oocyte maturation and activation, probably due to abnormal meiotic spindle and also with a reduction in both protein synthesis and total amount of mRNA in fully growth oocytes (Yu et al., 2004). The effects of these altered processes are a drop in fertility, litter size and developmental arrest during pre- or post-implantatory development. Indeed, we have previously reported that embryos from females fed ad libitum after rearing period for one month until reproduction presented lower gestational losses and higher litter size than those from restricted females (Naturil-Alfonso et al., 2016b). 
In conclusion, the restriction in food intake in females selected for growth rate did not alter the hypothalamus-hypophysis axis, but has consequences on oocyte quality. Alterations have been detected in the relevant gene MSY2 which could explain the previous differences observed in gestational losses and litter size. Additionally, these differences and also differences in fetal growth rate could be determined by the abnormal spindle configuration derived from MSY2 alterations, which can cause chromosome abnormalities and increase the incidence of aneuploidies (Luvoni, 2000). Therefore, further studies should be carried out on dietary needs of females with high growth rate, but also at other transcriptional levels, with techniques such as microarray analysis, massive sequencing or proteomic analysis for in-depth study of the mechanisms underlying the oocyte alterations observed.

\section{REFERENCES}

Alexander BM, Kiyma Z, McFarland M, Van Krik EA, Hallford DM, Hawkins DE, Kane KK, Moss GE. 2007. Influence of short-term fasting during the luteal phase of the oestrous cycle on ovarian follicular development during the ensuing proestrous of ewes. Anim Reprod Sci 97 356-363.

Armstrong DG, McEvoy TG, Baxter G, Robinson JJ, Hogg CO, Woad KJ, Webb R, Sinclair KD. 2001. Effect of dietary energy and protein on bovine follicular dynamics and embryo production in vitro: associations with the ovarian insulin-like growth factor system. Biol Reprod 64 1624-1632.

Asworth CJ, Antipatis C, Beattie L. 1999a. Effects of pre- and post-mating nutritional status on hepatic function, progesterone concentration, uterine protein secretion and embryo survival in Meishan pigs. Reprod Fertil Dev 1167 73. 
Asworth CJ, Beattie L, Antipatis C, Vallet J. 1999b. Effects of pre- and post-mating feed intake on blastocyst size, secretory function and glucose metabolism in Meishan gilts. Reprod Fertil Dev 11 323-327.

Balasubramanian P, Jagannathan L, Subramanian M, Gilbreath ET, MohanKumar PS, MohanKumar SMJ, 2012. High fat diet affects reproductive functions in female diet-induced obese and dietary resistant rats. J Neurondocrinol 24 748-755.

Baselga M. 2004. Genetic improvement of meat rabbits. Programmes and diffusion. In: Proc. 8th World Rabbit Congress, Puebla, Mexico, 1-13.

Blasco A. 1989. Genética y nutrición del conejo. In C. de Blas Alimentación del conejo. Ediciones Mundi, Prensa, Madrid.

Boland MP, Lonergan P, O'Callaghan D. 2001. Effect of nutrtion on endocrine parameters, ovarian physiology and oocyte and embryo development. Theriogenology 55 1323-1340.

Brecchia G, Bonanno A, Galeati G, Federici C, Maranesi M, Gobbetti A, Zerani M, Boiti C. 2006. Hormonal and metabolic adaptation to fasting: Effects on the hypothalamic-pituitary-ovarian axis and reproductive performance of rabbit does. Dom Anim Endocrinol 31 105-122.

Daoud NM, Mahrous KF, Ezzo OH. 2012. Feed restriction as a biostimulant of the production of oocyte, their quality and GDF-9 gene expression in rabbit oocytes. Anim Reprod Sci 136 121-127.

De la Fuente LF and Rosell JM. 2012. Body weight and body condition of breeding rabbits in commercial units. J Anim Sci 90 3252-3258.

Estany J, Camacho J, Baselga M, Blasco A, 1992: Selection response of growth rate in rabbits for meat production. Genet Sel Evol 24 527-537.

Ferguson EM, Ashworth CJ, Edwards SA, Hawkins N, Hepburn N, Hunter MG. 2003. Effect of different nutritional regimens before ovulation on plama concentrations of metabolic and reproductive hormones and oocyte maturation in gilts. Reproduction 126 61-71. 
García-García RM, Rebollar PG, Arias-Álvarez M, Sakr OG, BermejoÁlvarez P, Brecchia G, Gutierrez-Adan A, Zerani M, Boiti C, Lorenzo PL. 2011. Acute fasting before conception affects metabolic and endocrine status without impacting follicle and oocyte development and embryo gene expression in the rabbit. Reprod Fertil Dev 23 759-768

Gu W, Tekur S, Reinbold R, Eppig JJ, Choi YC, Zheng JZ, Murray MT, Hecht NB: 1998. Mammalian male and female germ cells express germ cell-specific $Y$ box protein, MSY2. Biol Reprod 59 1266-1274.

Kiyma Z, Alexander BM, Van Krik EA, Murdoch WJ, Hallford DM, Moss GE. 2004. Effects of feed restriction on reproductive and metabolic hormones in ewes. J Anim Sci 82 2548-2557.

Labreque R, Vigneault C, Blondin P, Sirard MA. 2014. Gene expression analysis of bovine oocytes at optimal coasting time combined with $\mathrm{GnRH}$ antagonist during the no-FSH period. Theriogenology 81 1092-1100.

Luvoni GC. 2000. Current progress on assisted reproduction in dogs and cats: in vitro embryo production. Reprod Nutr Dev 40 505-512.

Mahmoud KGH, Mobarak MS, Farghaly AA, Shahein YE, Ezzo OH. 2006. Effect of dietary restriction on genetic material and reproductive performance in rabbit. Egypt J Genet Cytol 35 129-143.

Martin B, Golden E, Carlson OD, Egan JM, Mattson MP, Maudsley S. 2008. Caloric restriction: Impact upon pituitary function and reproduction. Ageing Res Rev 7 209-224.

Moussa M, Shu J, Zhang XH, Zeng F. 2015. Maternal control of oocyte quality in cattle "a review". Anim Reprod Sci 155 1 1-27.

McEvoy TG, Robinson JJ, Atiken RP, Findlay PA, Palmer RM, Robertson IS. 1995. Dietary-induced suppression of preovulatory progesterone concentrations in superovulated ewes impairs the subsequent in vivo and in vitro development of their ova. Anim Reprod Sci 39 89-107. 
Naturil-Alfonso C, Marco-Jiménez F, Jiménez-Trigos E, Saenz-de-Juano MD, Viudes-de-Castro MP, Lavara R, Vicente JS. 2015. Role of embryonic and maternal genotype on prenatal survival and foetal growth in rabbit. Reprod Domest Anim 50 312-320.

Naturil-Alfonso C, Lavara R, Millán P, Rebollar PG, Vicente JS, MarcoJiménez F. 2016a. Study of failures in a rabbit line selected for growth rate. World Rabbit Sci 24 47-53.

Naturil-Alfonso C, Lavara R, Vicente JS, Marco-Jiménez F. 2016b. Effects of Female Dietary Restriction in a Rabbit Growth Line During Rearing on Reproductive Performance and Embryo Quality. Reprod Domestic Anim $51114-$ 22.

O'Callaghan D, Yaakub H, Hyttel P, Spicer LJ, Boland MP. 2000. Effect of nutrition and superovulation on oocyte morphology, follicular fluid composition and systemic hormone concentrations in ewes. J Reprod Fertil 118 303-313.

Papadopoulos S, Lonergan P, Gath V, Quinn KM, Evans AC, O'Callaghan D and Boland MP. 2001. Effect of diet quantity and urea supplementation on oocyte and embryo quality in sheep. Theriogenology 55 1059-1069.

Rommers JM, Meijerhof R, Noordhuizen JPTM, Kemp B. 2004. Effect of feeding program during rearing and age at first insemination on performances during subsequent reproduction in young rabbit does. Reprod Nutr Dev 44321 332.

Smith JT, Acohido BV, Clifton DK, Steiner RA. 2006. KiSS-1 neurons are direct targets for leptin in the ob/ob mouse. J Neuroendocrinol 18 298-303.

Tripp MW, JU JC, Hoagland TA, Riesen JW, Yang X, Zinn SA, 2000: Influence of somatotropin and nutrition on bovine oocyte retrieval and in vitro development. Theriogenology 53 1581-1590.

Vicente JS, Llobat L, Viudes-de-Castro MP, Lavara R, Baselga M, MarcoJiménez F. 2012. Gestational losses in a rabbit line selected for growth rate. Theriogenology 77 81-88. 
Viudes-de-Castro M.P., Vicente J.S. 1997. Effect of sperm count on the fertility and prolificity traits of meat rabbits. Anim Reprod Sci 46 313-31.

Yan J, Zhou B, Jie A, Yang J, Tai P, Chen X, Zhang H, Zhang M, Xia G. 2008. Glucose can reverse the effects of acute fasting on mouse ovulation and oocyte maturation. Reprod Fertil Dev 20 703-712.

Yu J, Hecht NB, Schultz RM. 2001. Expression of MSY2 in mouse oocytes and preimplantatory embryos. Biol Reprod 65 1260-1270.

Yu J, Deng M, Medvedev S, Yang J, Hecht NB, Schultz RM. 2004. Transgenic RNAi-mediated reduction of MSY2 in mouse oocytes results in reduced fertility. Dev Biol 268 195-206. 


\section{Effects of female dietary restriction in a rabbit growth line}

\section{during rearing on reproductive performance and embryo}

\section{quality}

C. Naturil-Alfonso', R. Lavara'1,2, J.S. Vicente' ', F. Marco-Jiménez'

'Institute of Science and Animal Technology, Laboratorio de Biotecnología de la Reproducción, Universidad Politécnica de Valencia, Camino de Vera s/n, 46022 Valencia, Spain

2Department of Production and Animal Health, General Veterinary Health and the Science and Technology of Food Products, University CEU Cardenal Herrera, Tirant lo Blanc 7, 46115 Valencia, Spain

Reproduction in Domestic Animals. 2016 51:114-122.

This work was supported by the Spanish Research Project AGL2014- 53405-C2-1-P (CICYT). Carmen Naturil was supported by a research grant from the Education Ministry of the Valencian Regional Government (programme VALi+d. ACIF/2013/296). 



\section{ABSTRACT}

Maternal diet prior to mating has an effect on reproductive performance. We analysed the effect of maternal dietary restriction during rearing on reproductive performance, the embryo development and fetal growth. Females were categorised in two groups; (i) does with ad libitum access to feed or (ii) restricted. Two experiments were performed: (1) After one month receptive females from both experimental groups were artificially inseminated and the reproductive performance was recorded during 3 reproductive cycles; at the first insemination, the body weight and perirenal fat thickness were recorded. (2) Females from both experimental groups were inseminated and $24 \mathrm{~h}$ later embryos were recovered and transferred to recipient females from a maternal line. Later, embryonic implantation was assessed at Day 14 by laparoscopy and fetal growth was monitored by ultrasound examination. In experiment 1, no differences in kindling rate was found, but prolificacy was showed to be higher in ad libitum does, which also were heavier than resticted ones. In experiment 2, no differences among does either in body weight, perirenal fat thickness or reproductive performance (ovulation rate and embryo recovery rate) were related to differences in feed intake. However, despite similar embryonic implantation losses, embryos from restricted females demonstrated higher fetal and gestational losses. Embryos from restricted does presented lower fetal growth than embryos from ad libitum does. Therefore, our results demonstrated that nutrition before first conception in a rabbit line selected for growth rate may impact on the embryo, and results in a disturbance in gestational losses and fetal growth over all reproductive life. 



\section{INTRODUCTION}

Rabbit lines selected for growth rate are characterised by high feed intake, elevated growth rate and adult live weight (Estany et al., 1992), reduced reproductive performance (Mehaisen et al., 2004; Vicente et al., 2012), and also by an elevated disease incidence despite higher body condition score (Sánchez et al., 2012). Vicente et al. (2013a) reported that a rabbit paternal line selected for growth rate presented worse prenatal survival and gestational losses, of $50 \%$, compared with maternal lines. Additionally, these and other authors (Ernst et al., 2000) showed that embryo genotype from females selected for growth rate had a significant effect on embryo survival at implantation and fetal survival rate. Hence this line could serve as a natural model to study the relationship between reproduction, energy balance and feed efficiency (Vicente et al., 2012).

On the one hand, survival and prenatal growth of mammalian embryos have shown to be influenced by the genotype of the embryo, genotype of the uterus providing the optimal embryo developmental environment and their interaction (Wilmut et al., 1986). Developing embryos are influenced by maternal inherited effects, including cytoplasmic heritage, maternal age and maternal body size (Cowley, 1991a,b). These maternal effects are often classified as epigenetic factors as they condition the progeny gene expression and therefore alter the relationship between genotype and phenotype in the progeny (Cowley et al., 1989; Atchley et al., 1991; Atchley and Hall, 1991). Embryo genotype has been shown to modify uterine secretions, altering uterine tissue and affecting embryo survival rate and litter size (Wilson and Ford, 1997). Additionally, Mocé et al. (2004) reported that the genotype of the embryos only 
has a relevant effect on embryo survival in a favourable maternal environment. Specifically, Vicente et al. (2013a) showed that embryo genotype in rabbit affects fetal survival and weight at day 25 of gestation, while maternal genotype was responsible for implantation. More recently, it was shown that embryonic genotype influences prenatal survival and fetal weight at early gestation, and both embryonic and maternal genotypes influenced placental weight at middle and late gestation (Naturil-Alfonso et al., 2015).

On the other hand, reproductive function has shown to be highly related with reproductive performance (Fortun-Lamothe, 2006). Although nutritional regimens after mating can have an effect, more data indicate that modifications to the nutritional regimen before mating may have greater impact on embryo survival and uniformity of litter size than the diet after mating (Ashworth et al., 1999a,b). Several reports have established that an altered nutritional regimen prior to mating can influence follicular/oocyte characteristics, but also that the maternal diet during pre-implantation development acts as a signalling input to the early embryo to regulate its future growth, as the peri-implantation period is a key period for future embryo development (Edwards and McMillen, 2002; MacLaughlin et al., 2005; Watkins et al., 2008; Picone et al., 2011; Daoud et al., 2012). Moreover, maternal body weight or body condition before or immediately after conception may play a role in foeto-placental growth in early pregnancy, altering the weight of the fetal membranes and individual fetal weight (MacLaughlin et al., 2005).

The aim of this study was to evaluate the influence of feed restriction during rearing on reproductive performance and embryo development and survival, in a rabbit line selected for growth rate. 


\section{MATERIAL AND METHODS}

All chemicals used in this study were purchased from Sigma-Aldrich Química S.A. (Madrid, Spain) unless stated otherwise.

\section{Ethical Statement}

The experiment was performed in accordance with the principles of animal care published by Spanish Royal Decree 53/2013 (BOE 2013). The animal studies were approved by the Committee of Ethics and animal Welfare of the Universidad Politécnica de Valencia (procedure 2015/vsc/PEA/00061). Researchers involved in the work with the animals possessed an animal experimentation license issued by the Spanish authorities.

\section{Animals}

Rabbits used in this experiment came from two commercial lines generated at the experimental farm of the Universidad Politécnica de Valencia. Animals were from a synthetic line selected for growth rate between weaning and slaughter time (9 $9^{\text {th }}$ wk of life) for 36 generations (Estany et al., 1992; named line R). Recipient females were from a New Zealand White origin selected by family index for litter size at weaning for 43 generations (Estany et al., 1989; named line A). Does were housed individually at 12 wk of age, with free access to water, under $16 \mathrm{~h}$ light/8 h dark photoperiod, unless stated below.

At the age of four months, females from a line selected for growth rate were divided into two experimental groups: feeding ad libitum or restricted (provided daily with $130 \mathrm{~g} /$ day to accomplish with energy requirements for maintenance: $340 \mathrm{~kJ} \mathrm{day}^{-1} \mathrm{~kg}^{-1}$ LW0.75; Xiccato and Trocino, 2010). Rabbits were fed with a commercial rabbit diet (on dry matter basis: $17.5 \%$ crude protein, $3.5 \%$ ether 
extract, $16.7 \%$ crude fibre, $2938 \mathrm{kcal} / \mathrm{kg})$. After one month under these experimental conditions, females were reproduced. The feed intake of ad libitum does was determined by weighing the feeder at the beginning and end of each week, and all feed supplies given within a week were recorded. Additonally, when a restricted doe was tested as pregnant, the diet was established as an ad libitum regimen.

\section{Experiment 1. Effect of feeding regimen on reproductive performance}

A total of twenty-six does (12 ad libitum and 14 restricted) were employed. Receptivity of does was determined observing the vulvar color and turgescency, considering receptive those with red/purple and swollen vulva. When receptive, does were artificially inseminated with $0.5 \mathrm{~mL}$ of fresh heterospermic pool of males from the same line selected for motility criteria (more than $70 \%$ of motility rate and less than $15 \%$ of abnormal sperm) and diluted 1:5 with tris-citric-glucose diluent (Viudes-de-Castro and Vicente, 1997). Immediately after insemination, ovulation was induced by an intramuscular injection of $1 \mu \mathrm{g}$ of Busereline Acetate (Suprefact, Hoechst Marion Roussel, S.A., Madrid, Spain).

Body weight and body composition of rabbit does were determined at the moment of the first Al. The perirenal fat thickness (PFT) of does was measured by ultrasound to evaluate body condition, as described by Pascual et al. (2000). Briefly, images were obtained with an ultrasound unit (Justvision 200 "SAS-320A" real-time sound machine, Toshiba), equipped with an electronic micro-convex transducer of multi-frequency (5.0, 6.0 and 7.0-MHz; PVG-681S). PFT measures were indirectly obtained using the software of the ultrasound unit. At the moment of the PFT measurement, does were also weighted. 
Fertility was evaluated during 3 reproductive cycles. Second and third inseminations were performed 12 days post-kindling, when insemination was tested as non-pregnant, next Al was performed 21 days after the previous one. Weaning was performed $30 \mathrm{~d}$ post-kindling. Fertility was defined at kindling as kindling followed insemination or no kindling. The corresponding variable is the kindling rate (KR). Prolificacy was defined as number of total born/number of inseminations.

\section{Experiment 2. Effect of feeding regimen on embryo development and fetal growth}

\subsection{Embryo recovery}

From the previous females, nineteen donor does after weaning of third parity (7 ad libitum and 12 restricted) were artificially inseminated, as previously described. Twenty-four hours post-insemination, females were euthanised with an intravenous injection of $200 \mathrm{mg} / \mathrm{kg}$ of pentobarbital sodium (Dolethal, Vétoquinol, Madrid, Spain). Embryos were recovered by perfusion of each oviduct and uterine horn with $10 \mathrm{~mL}$ of pre-warmed Dulbecco Phosphate Buffered Saline supplemented with $0.2 \%$ of Bovine Serum Albumin. The ovulation rate and embryo recovery rate was recorded for each female. Ovulation and embryo recovery rate were calculated as the number of corpora lutea in both ovaries (OR) and the number of embryos recovered in each female (ER), respectively. Previously, females were weighed and after euthanasia, the perirenal fat was dissected and weighted.

\subsection{Embryo transfer by laparoscopy}

A total of 48 embryos from ad libitum females and 84 embryos from restricted females were transferred into oviducts by laparoscopy to 10 recipient does 11 
to 16 embryos per recipient) following the procedure described by Besenfelder and Brem (1993). Ovulation was induced in recipient does with an intramuscular dose of $1 \mathrm{\mu g}$ of Busereline Acetate $24 \mathrm{~h}$ before transfer. Briefly, recipients were sedated by intramuscular injection of 16 mg xylazine (Rompun; Bayer AG, Leverkusen, Germany). As surgical preparation for laparoscopy, anaesthesia was performed by intravenous injection of 16 to $20 \mathrm{mg}$ of ketamine hydrochloride (Imalgene; Merial, S.A., Lyon, France) into the marginal ear vein. During laparoscopy, $12 \mathrm{mg}$ of morphine hydrochloride (Morfina; B. Braun, Barcelona, Spain) was administered intramuscularly. First, the abdominal region was shaved, and the animals were then placed on an operating table in a vertical position (head down at $45^{\circ}$ angle). Only an endoscope trocar was inserted into the abdominal cavity. When the trocar was removed, the abdomen was insufflated with $\mathrm{CO}_{2}$ and the endoscope was then inserted. For embryo transfer, embryos were aspirated in a 17-gauge epidural catheter (Vygon Corporate, Paterna, Valencia) introduced into the inguinal region with an epidural needle and then inserted into the oviduct through the infundibulum. After surgery, does were treated with antibiotics $(0.1 \mathrm{~mL} / \mathrm{kg}$ of procaine penicillin, Duphapen Strep; Pfizer, S.L.) and buprenorphine hydrochloride $(0.08 \mathrm{mg}$ every 12 hours for 3 days, Buprex; Esteve, Barcelona, Spain).

\subsection{Embryonic implantation, delivery and losses rates}

A total of 10 laparoscopies were carried out $12 \mathrm{~d}$ post-insemination. The number of implanted embryos (IE) and total born/litter size (TB) were recorded per female. Implantation and gestational losses were calculated, respectively, as the number of transferred embryos that did not reach the implantation or 
fetal stage. Fetal losses were defined as the proportion of implanted embryos that did not reach the fetal stage in pregnant does.

\subsection{Ultrasound examination}

Fetal growth was examined from day 12 post-insemination, at days 12, 14, 16 , $19,21,23,26$ and 28 by a portable colour Doppler ultrasound device (Esaote, Spain) with 7.5 MHz linear probe (4-12 MHz range). Prior to examination, does were anaesthetised with ketamine $35 \mathrm{mg} / \mathrm{kg}$ and xylazine $5 \mathrm{mg} / \mathrm{kg}$ intramuscularly and the abdomen of the doe was clipped. Does were placed in a polystyrene cage where they were prevented from moving. The ultrasound examination was performed from right to left with the probe in sagittal orientation and, after localisation of different fetal sacs, 5 to 7 fetal sac examinations per doe were performed. Foetus was measured from frozen frame pictures on the monitor, using the Esaote 16 ultrasound software (Figure 4.1). Additionally, litter size was recorded at birth.

Fetal growth was determined by the linear distribution of crown-rump length (CRL) measurements, each $2 \mathrm{~d}$ of gestation (Vicente et al., 2013b). 

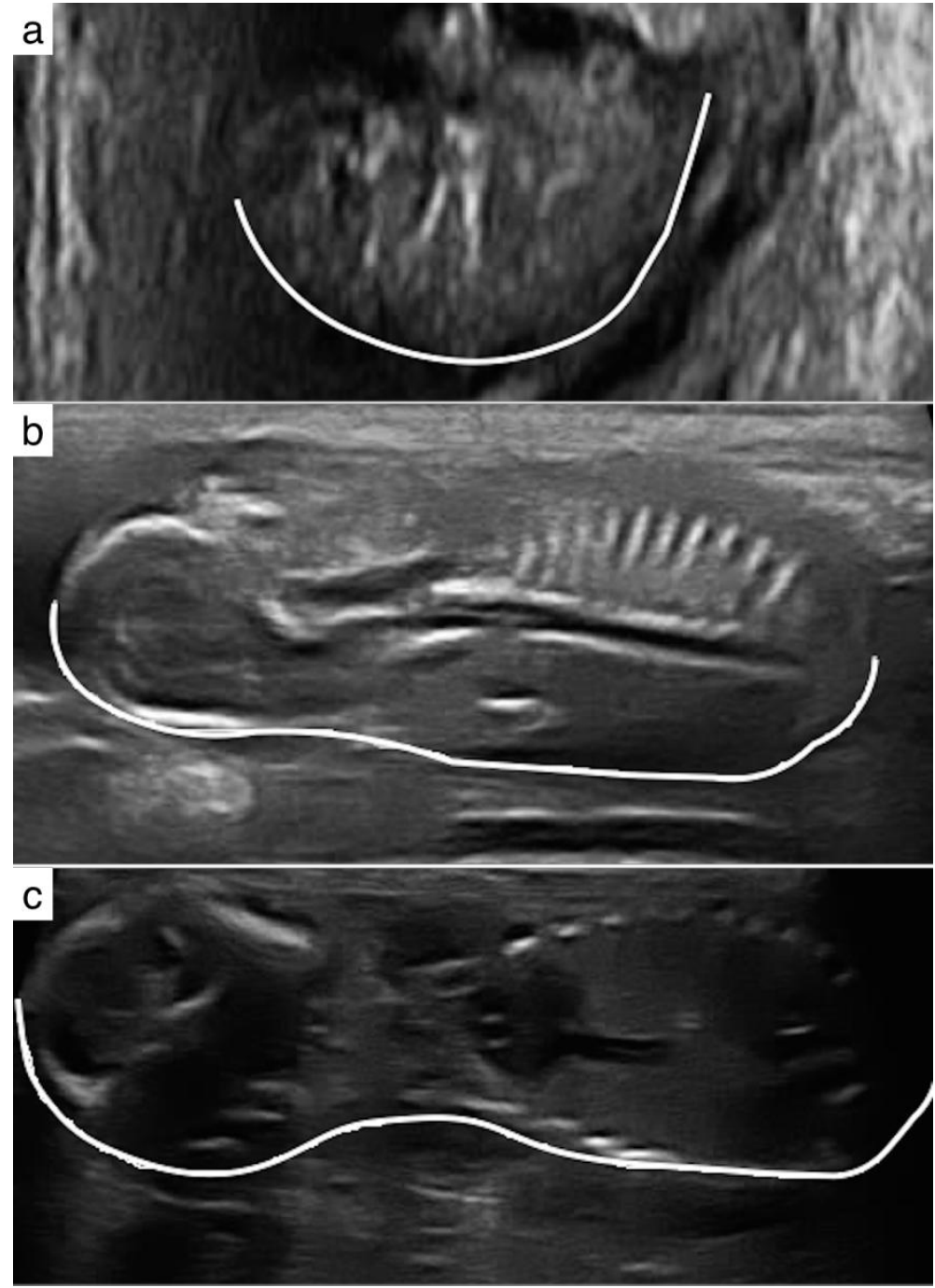

Figure 4.1. Ultrasound measurements of the crown-up length (CRL) of foetus at different days of gestation. (a) At 14 days (b) At 21 days (c) At 28 days.

A scheme of the experimental procedure is presented in Figure 4.2. 


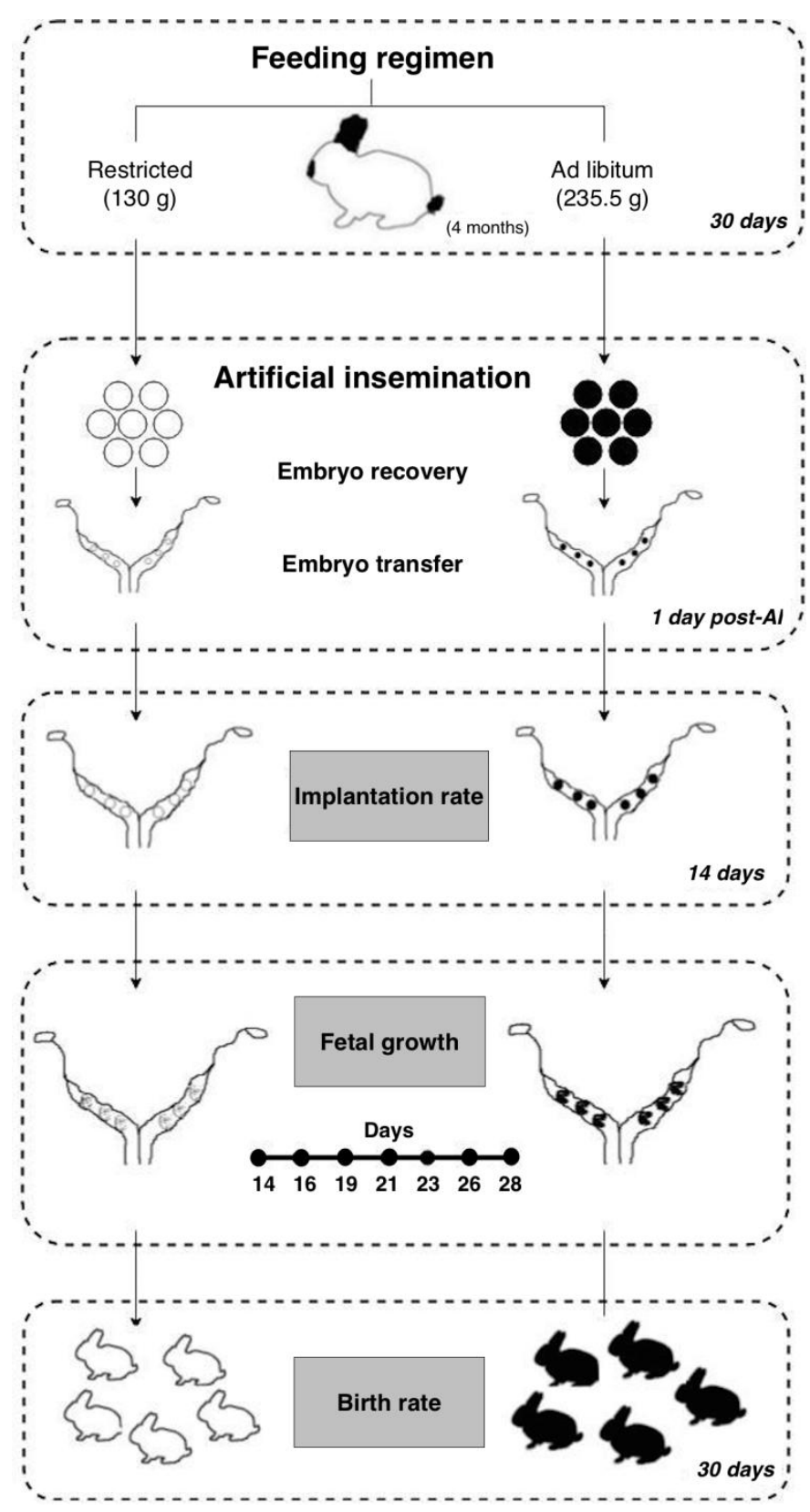

Figure 4.2. Schematic illustration of the experimental procedure used in experiment 2 to determine the effect of maternal feeding prior to mating on the embryo.

\section{Statistical analysis}

\subsection{Experiment 1. Effect of feeding regimen on reproductive performance}

Kindling rate was analyzed by a GLM including the type of feeding with two levels (ad libitum or restricted) as a fixed factor. The error was designated as having a binomial distribution using the probit link function. Bionomial data for 
fertility was assigned a value of one if kindling followed insemination. Failure to insemination resulted in a score of zero. Prolificacy and body condition (weight and PFT) differences between groups were analyzed with a generalized linear model including the type of feeding with two levels (ad libitum and restricted) and parity ( 1 to 3 ) as a fixed effect.

\subsection{Experiment 2. Effect of feeding regimen on embryo development and fetal growth}

For donor females, a GLM was performed to determine differences in body weight, PTF, OR and ER, among groups (ad libitum and restricted does).

To compare implantational, gestational and fetal losses between groups, a GLM was performed including the origin of embryo with two levels (ad libitum or restricted) as fixed effect. The error was designated as having a binomial distribution using the probit link function. Bionomial data for implantation, gestational and fetal losses per embryo were assigned a value of one if implantation occurred after transfer, if birth took place, or if birth took place from implantations, respectively. Failure to implant or continue development from implantation to birth resulted in a score of zero.

Litter size differences between groups were analysed with a general linear model including the origin of embryo with two levels (ad libitum or restricted) as fixed effect.

Regression Model Selection was used to determine a model that best evaluated fetal growth. The variables tested were female, litter size, and days of gestation. Additionally, the Group was included as a category variable (ad libitum or restricted). The model was selected by stepwise procedure based on 
Akaike Information Criteria (AIC). Later, a multiple regression analysis was performed to test the significance of each parameter.

Differences of $P<0.05$ were considered significant. Data are shown as means \pm standard error means (S.E.M.). All analyses were performed with SPSS 16.0 software package (SPSS Inc., Chicago, Illinois, USA, 2002).

\section{RESULTS}

\section{Experiment 1. Effect of feeding regimen on reproductive performance}

During the three reproductive cycles, from the total of 26 females ( 12 ad libitum and 14 restricted), only 16 got pregnant after Al. Between groups, no differences in kindling rate were found $(0.6 \pm 0.08$ vs. $0.4 \pm 0.07$, for ad libitum and restricted females, respectively). Prolificacy was higher in ad libitum females during all of reproductive cycles (Table 4.1).

Donor females fed ad libitum showed significantly increased ingestion (235.5 \pm $6.87 \mathrm{~g} /$ day) compared to the restricted group (130.0 g/day). At the moment of first Al ad libitum females showed to be heavier than restricted ones $(5.3 \pm 0.30$ kg vs. $4.6 \pm 0.28 \mathrm{~kg}$, for ad libitum and restricted females, respectively), while no difference in PFT was detected $(9.2 \pm 0.30 \mathrm{~mm}$ vs. $8.7 \pm 0.28 \mathrm{~mm}$, for ad libitum and restricted females, respectively). 
Table 4.1. Reproductive performance and body condition in ad libitum and restricted females after the rearing period.

\begin{tabular}{|c|c|c|c|c|}
\hline Type & $\begin{array}{c}\text { Feed consumption } \\
\text { (g/day) }\end{array}$ & Kindling rate & Body weight $(\mathbf{k g})$ & PTF (mm) \\
\hline$A D(N=12)$ & $235.5 \pm 6.87$ & $0.6 \pm 0.08$ & $5.3 \pm 0.30^{a}$ & $9.2 \pm 0.30$ \\
\hline$R(N=14)$ & $130.0 \pm 0.00$ & $0.4 \pm 0.07$ & $4.6 \pm 0.28^{b}$ & $8.7 \pm 0.28$ \\
\hline & \multicolumn{4}{|c|}{ Kindling order } \\
\cline { 2 - 5 } & $\mathbf{1}^{\text {st }}$ & 2nd & 3rd & TOTAL \\
\hline$A D(N=12)$ & $4.1 \pm 0.30^{a}(N=12)$ & $5.0 \pm 0.32^{a}(N=11)$ & $5.3 \pm 0.56^{a}(N=8)$ & $4.8 \pm 0.17 a$ \\
\hline$R(N=14)$ & $3.2 \pm 0.28^{b}(N=14)$ & $3.1 \pm 0.27 b(N=14)$ & $3.2 \pm 0.24^{b}(N=11)$ & $3.2 \pm 0.15^{b}$ \\
\hline
\end{tabular}

$A D$ : female fed ad libitum during rearing; R: female fed restricted during rearing; $\mathrm{N}$ : number of females. Data are presented as least square means \pm standard error. Different superscripts represent a difference $(P<0.05)$.

\section{Experiment 2. Effect of feeding regimen on embryo development and fetal growth}

\subsection{Donor females}

No significant differences were found between females fed ad libitum and restricted either in body weight or in perirenal fat weight $(6.9 \pm 0.23 \mathrm{~kg}$ and $6.5 \pm$ $0.17 \mathrm{~kg}$, body weight and $142.3 \pm 19.46 \mathrm{~g}$ and $103.06 \pm 14.87 \mathrm{~g}$ fat weight, for ad libitum and restricted females, respectively).

Likewise, reproductive parameters showed no significant differences between both types of females. From the nineteen females, five of them $(3 \mathrm{ad}$ libitum and 2 restricted) did not produce embryos. From the others 14, ovulation rate was $13.3 \pm 1.65$ and $12.9 \pm 1.08$ for ad libitum and restricted donor females, respectively. The embryo recovery frequency was $92 \%$ and $95 \%$, for ad libitum and restricted donor females respectively, while the embryo recovery was 12.3 \pm 1.56 and $12.3 \pm 1.02$, respectively. 


\subsection{Embryonic implantation, birth rate, fetal and gestational losses}

Figure 4.3 shows implantation, gestational and fetal losses of ad libitum and restricted transferred embryos. Whereas implantation losses did not show differences between both groups of embryos $(0.20 \pm 0.044$ vs. $0.25 \pm 0.063$, for restricted and ad libitum derived embryos, respectively), gestational and fetal losses showed significant differences between them (0.58 \pm 0.054 vs. $0.40 \pm 0.071$ and $0.48 \pm 0.061$ vs. $0.19 \pm 0.066$, for restricted and ad libitum derived embryos, in gestational and fetal losses, respectively). Additionally, LS was higher for ad libitum transferred embryos $(9.3 \pm 0.09$ vs. $7.5 \pm 0.07$, total born for ad libitum and restricted embryos, respectively).

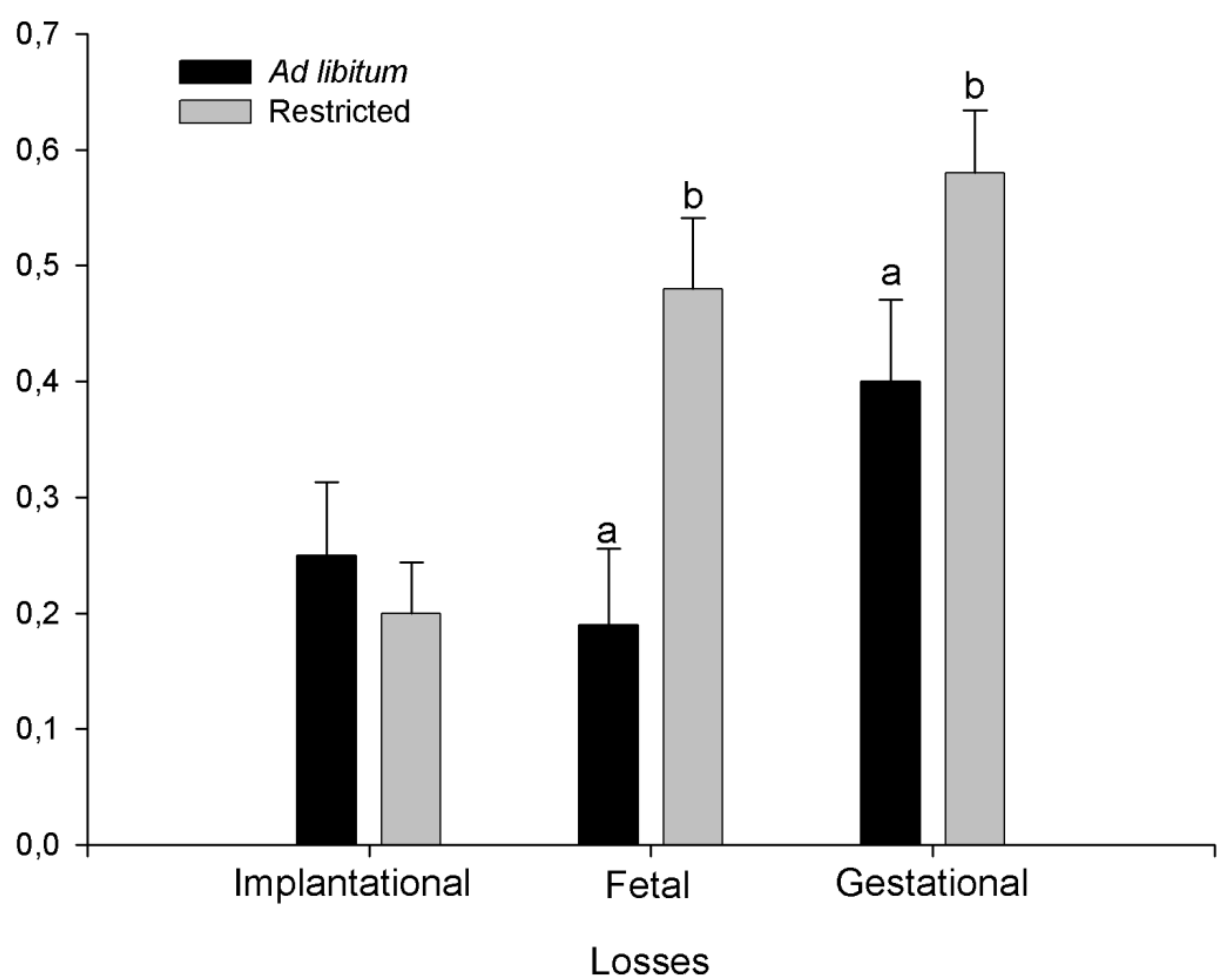

Figure 4.3. Implantational, fetal and gestational losses for embryos derived from restricted and ad libitum fed females. Bars with different letters are significantly different $(p<0.05)$. 


\subsection{Fetal growth}

The regression model that includes Days of gestation (D) and Group (G: Ad libitum or restricted) as independent variables could explain nearly $95 \%$ of the variation in fetal growth measured as CRL (residual standard error: 0.67). The standardized coefficient was $\beta=0.49$ (S.E: $0.15, p<0.05$ ) for days of gestation, and $\beta=-0.19$, (S.E: $0.01, p<0.05$ ) for group (referred to restricted group). These results showed differences in growth rates measured in CRL between both groups with the ad libitum embryos showing higher fetal growth $(+0.19 \mathrm{~cm} /$ day) than restricted embryos at the same day of gestation.

\section{DISCUSSION}

It is widely known that maternal nutrition and body condition prior to mating or immediately after, during pre-implantation development, affects the establishment and the growth trajectory of the foetus (MacLaughlin et al., 2005; Watkins et al., 2008; Picone et al. 2011; Daoud et al. 2012). The current study shows that does from a line selected by growth rate with feed restriction during rearing, might be disadvantaged in terms of oocyte reserve quality or fertilization process that conditioned embryo survival, increasing fetal and gestational losses and limiting fetal growth.

The experimental group developed and analyzed in experiment 1 showed that ad libitum females presented higher fertility than restricted ones, although not statistically significant, which could be explained by the relative low number of animals. Indeed, ad libitum are heavier and present higher prolificacy than restricted ones. The feeding regimen leading to a higher body weight and prolificacy could be altering the fertilization process, uterine environment or the 
oocyte, which would be manifested at the embryo level. With this aim, in the experiment 2 we analyzed the effect of the feeding regimen on the embryos produced by both types of females.

First, feed intake for does that were fed ad libitum was evaluated. In general, heavy does are heavier as a consequence of higher feed intake or a higher growth potential (Rommers et al., 2002), which was not the case in our study. Our results showed that although ad libitum diet showed an ingestion increase of $105.5 \mathrm{~g} /$ day more than restricted, ad libitum does were not heavier and over-fattening had not occur at the moment of embryo recovery. Picone et al. (2011) reported similar results in rabbits, finding no differences in body weight gain and in fat weight between females following a hypercholesterolemic and hyperlipidic diet and females following a control diet from week 10 to 18 of age. Additionally, Rommers et al. (2002) indicated that after rearing period, heavy does had not formed relatively more fat tissue compared to medium and small does. Moreover, as other authors have reported in females submitted to alter feeding regimens, our data did not reveal differences in ovulation and embryo recovery rate and embryo recovery percentage between ad libitum and restricted donor females (Kwong et al., 2000; Tripp et al., 2000; Cardinali et al., 2008). However, nutritional diet during rearing not only affects body condition, but also has shown to alter metabolic and reproductive hormones influencing fertility (Brecchia et al., 2006).

In our work, embryos were transferred to females from a maternal line to analyse only the embryonic origin effect and discard the endometrial environment effect, as this maternal environment has been shown to be better for embryo development and fetal survival than the uterine environment of line 
R (Naturil-Alfonso et al., 2015). When embryos from ad libitum and restricted does were transferred to a female from a maternal rabbit line, they reached a similar implantation rate, and therefore, similar implantation losses were observed. However, fetal and gestational losses were higher in embryos originated in restricted females, doubling gestational losses of ad libitum ones. In a similar way, litter size of ad libitum embryos was higher than in restricted. Discrepancies are found in the literature about the influence of diet and body condition on pregnancy establishment and miscarriages. On the one hand, similar implantation rate and litter size in females following a control or an ad libitum low protein diet has previously been reported (Kwong et al., 2000). On the other hand, decreased pregnancy rates and high miscarriages rates have been observed in response to obesity in women (Robker, 2008) or in ewes with high feed intake (Parr et al., 1987).

However, our results are in contrast to those reported in rabbit. Petrere et al. (1993) described no effect of feed restriction (150 g/day) on post-implantation losses compared with ad libitum ones (220 g), similar to Cappon et al. (2005) in fetal viability. This disagreement may be produced by the line studied, as these studies worked with a maternal line while our work was carried out with a paternal one. Rabbit paternal lines are characterised by reduced reproductive performance, with the highest implantational, gestational, fetal and perinatal losses (Mehaisen et al., 2004; Vicente et al., 2012). Previously, it has been shown that embryonic genotype influences implantation and fetal survival, being lower in does of paternal lines when compared with a maternal line as reference, but maternal genotype also affects implantation rate (Vicente et al., 2013a). More recently, Naturil-Alfonso et al. (2015) reported that embryonic 
genotype influences prenatal survival at early gestation, which is in contrast with our results as the survival rate at Day 14 (implantation rate) was the same between groups. Thus, the differences between groups may be attributed to the model employed.

In addition, restricted derived foetuses showed lower fetal growth from implantation to birth (Figure 4.4). The vast majority of the studies analysing fetal growth in feed regimen altered conditions reported alterations in placental length, foetus birth weight and post-natal growth (Kwong et al., 2000; MacLaughlin et al., 2005; Picone et al., 2011; Cordier et al., 2013). As in our results, it was previously shown in rabbit does that hypercholesterolemic and hyperlipidic diet led to fetal growth differences between groups, with the main differences found at term of gestation (days 27 and 28) (Picone et al., 2011; Cordier et al., 2013).

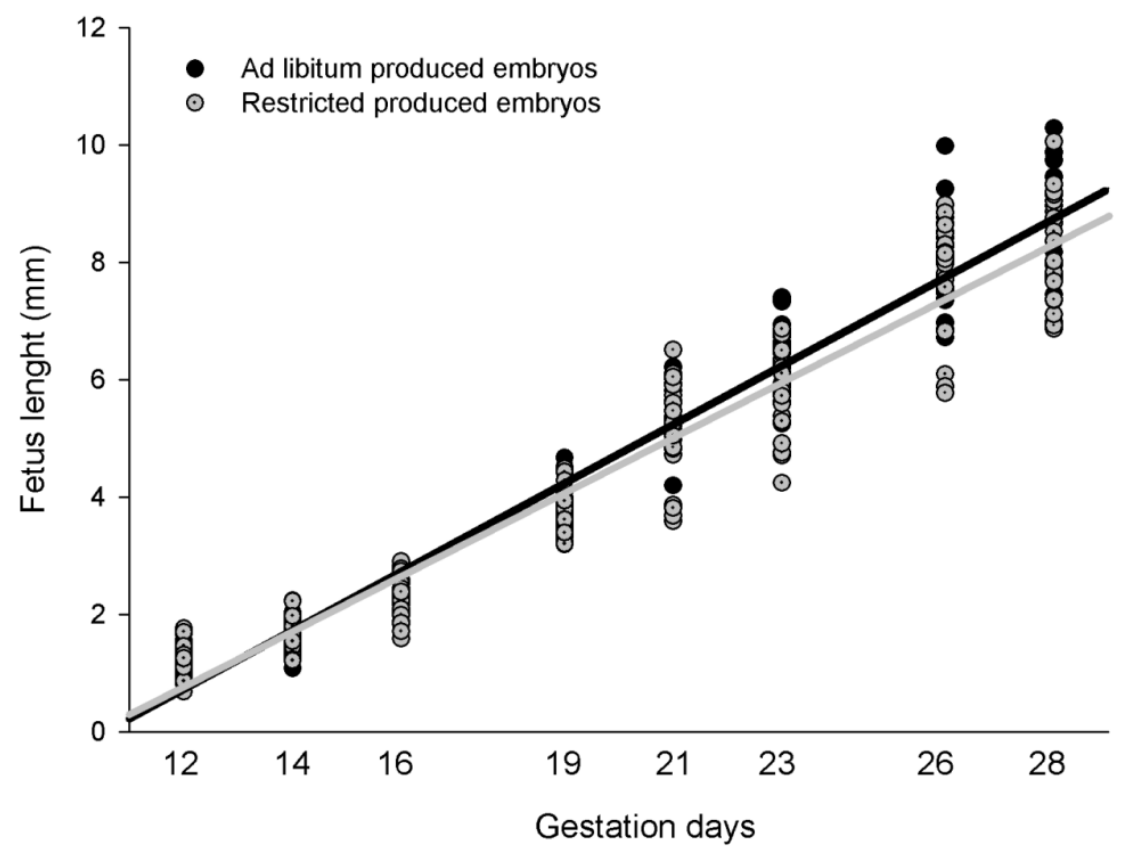

Figure 4.4. Regression lines of fetal growth from day 14 to 28 of gestation in surrogate females for ad libitum and restricted produced embryos. 
Our findings confirm that fetal growth is altered by the feeding regimen of the mother during rearing, and further suggest that this developmental trajectory is established during oocyte development and maturation. Previous studies reported that effects of under- or over-nutrition on embryo development begin at the ovarian levels (Wakefield et al., 2008; Igosheva et al., 2010; Luzzo et al., 2012). During oocyte growth phase, RNA and protein synthesis and storage take place (Crozet et al., 1981; Godsen et al., 1997). Meiotic progression up to MII, fertilisation and early embryonic development must be maintained by the stored RNA and proteins (Bachvarova, 1992). Additionally, acquisition of DNA methylation is mostly performed in antral follicles and Mll-ovulated oocytes (Saitou et al., 2012). This DNA methylation or methylation errors showed to still be present at blastocyst stage (Denomme and Mann, 2012). Deficiencies in these processes could lead to a decrease in developmental competence (Anguita et al., 2008). In fact, it was shown that pre-implantation embryo development can be reprogrammed during the final stage of oocyte maturation (Leroy et al., 2015). Recently, wu et al. (2015) have reported that oocytes from obese female mice fertilised in vitro have reduced potential to form blastocysts in vitro, but also when they were transferred to surrogate females fetal growth was higher in foetuses derived from oocyte of obese mice than from controls. These authors indicated that maternal obesity before conception alters developmental growth trajectory of the foetus already established during oocyte development and maturation, within the follicle or before fertilisation. This is consistent with our work, where results evidence those differences in nutrition before conception may affect oocytes in some way that is subsequently inherited by the embryo and is manifested at the level of fetal 
and gestational losses and fetal growth. In contrast, acute fasting of $72 \mathrm{~h}$ prior to Al has shown to alter metabolic and endocrine markers, but did not affect follicle and oocyte development in rabbits (García-García et al., 2011). However, our study focuses in long-term consequences (3 reproductive cycles and posterior embryos) of a long-restricted period during rearing, while GarcíaGarcía-García et al. (2011) studied the direct consequences of short fasting period on nulliparous does, which did not involved follicular development and oocyte competence as ovulated follicles of this cycle were already in development during the fasting period.

The alterations observed in this line selected by growth rate may be due to feed restriction. It could be that a slight negative energy balance during rearing in the restricted does might have affected the oocyte. Specifically in rabbits, Arias-Álvarez et al. (2009) reported that metabolic status of the female is associated with reproductive outcomes, as this status determines the acquisition of oocyte developmental competence, in terms of nuclear and cytoplasmic maturation.

As stated previously, these lines have serious reproductive issues, with high fetal and perinatal losses (Vicente et al., 2012). The way in which an animal accommodates a nutritional change will depend upon its priorities (Friggens, 2003). The genetic characteristics of this line could make does prioritise their own maintenance to that of the offspring, as there is a genetic component controlling size and mobilisation of body fatness, with high priority in safeguarding body reserves of the animals (Theilgaard, 2006). Thus, if these females are restricted during rearing they may have a lack of dietary intake capacity to meet the demands. So, when they eat ad libitum they have 
enough energy to supply their needs and also for the offspring, and consequently the gestational losses are reduced and the fetal growth is higher.

Therefore, we showed that a restricted diet in females selected for growth rate during rearing may alter the oocyte in some undetermined way, and consequently the embryo, which leads to an increase in the fetal and gestational losses when compared with losses of embryos from females with an ad libitum diet, and increases fetal growth and litter size. Considering this, and that (i) the last study reporting implantational, fetal and gestational losses for the rabbit line employed in this work (line R) showed results similar to ours in restricted embryos for fetal and gestational losses (Vicente et al., 2012); and (ii) embryonic genotype is mainly responsible for these losses; we can affirm that with a restricted diet during rearing we have altered the oocyte and embryo, and so increased the fetal and gestational losses and decreased fetal growth.

In conclusion, although no differences in weight, perirenal fat thickness, ovulation and embryo recovery rates are found between females fed ad libitum or restricted during rearing, fetal and gestational losses and fetal growth are altered between embryos produced by these females. Our study shows that when embryos came from feed restricted females, the gestational losses are those expected for this line and fetal growth is lower, while with an ad libitum diet gestational losses are reduced by half. It may be that restrictive nutrition affects oocytes and so alters the embryo, which in turns reduces gestational losses and fetal growth. Our results highlight the importance of periconceptional diet in oocytes and embryos of a rabbit line selected by growth characteristics. Thus, they call for further studies on oocytes and embryos to better understand the mechanisms responsible for the effects 
observed in this rabbit model, and also on the metabolism of this line to elucidate their energy management during gestation.

\section{REFERENCES}

Anguita B, Paramio MT, Jiménez-Macedo AR, Morató R, Mogas T, Izquierdo D. 2008. Total RNA and protein content, Cyclin Bl expression and developmental competence of prepubertal goat oocytes. Anim Reprod Sci $103290-303$.

Arias-Álvarez M, García-García RM, Rebollar PG, Revuelta L, Millán P, Lorenzo PL. 2009. Influence of metabolic status on oocyte quality and follicular characteristics at different postpartum periods in primiparous rabbit does. Theriogenology 72 612-623.

Ashworth CJ, Antipatis C, Beatti L. 1999a. Effects of pre- and post-mating nutritional status on hepatic function, progesterone concentration, uterine protein secretion and embryo survival in Meishan pigs. Reprod Fertil Dev $1167-$ 73.

Ashworth CJ, Beatti L, Antipatis C, Vallet. J. 1999b. Effets of pre- and postmating feed intake on blastocyst size, secretory function and glucose metabolism in Meishan gilts. Reprod Fertil Dev 11 323-327.

Atchley WR, and Hall BK. 1991. A model for development and evolution of complex morphological structures. Biol Rev 66 101-157.

Atchley WR, Logsdon TR, Cowley DE, Eisen EJ. 1991. Uterine effects, epigenetics and postnatal skeletal development in the mouse. Evolution 45891 909.

Bachvarova RF. 1992. A maternal tail of poli(A): the long and the short of it. Cell $69895-897$.

Besenfelder U, Brem G. 1993. Laparoscopic embryo transfer in rabbits. J Reprod Fertil 99 53-56. 
Brecchia G, Bonanno A, Galeati G, Federici C, Maranesi M, Gobbetti A, Zerani M, Boiti C. 2006. Hormonal and metabolic adaptation to fasting: Effects on the hypothalamic-pituitary-ovarian axis and reproductive performance of rabbit does. Domest Anim Endocri 31 105-122.

Cappon GD, Fleeman TL, Chapin RE, Hurtt ME. Effects of feed restriction during organogenesis on embryo-fetal development in rabbit. 2005. Birth Defects Research 74 424-430.

Cardinali R, Dal Bosco A, Bonanno A, Di Grigoli A, Rebollar PG, Lorenzo $\mathrm{PL}$, Castellini C. 2008. Connection between body condition score, chemical characteristics of body and reproductive traits of rabbit does. Livest Sci 116209 215.

Cordier AG, Léveille P, Dupont C, Tarrade A, Picone O, Larcher T, Dahirel M, Poumerol E, Mandon-Pepin B, Lévy R, Chavatte-Palmer P. 2013. Dietary lipid and cholesterol induce ovarian dysfunction and abnormal $\mathrm{LH}$ response to stimulation in rabbits. Plos one 8 e63101.

Cowley DE, Pomp D, Atchley WR, Eisen EJ, Hawkins-Brown D. 1989. The impact of maternal uterine genotype on postnatal growth in adult body size in mice. Genetics 122 193-203.

Cowley DE. 1991a. Genetic prenatal maternal effects on organ size in mice and their potential contribution to evolution. J Evol Biol 3 363-381.

Cowley DE. 1991b. Prenatal effects on mammalian growth: embryo transfer results. Proceedings of the $4^{\text {th }}$ International Congress if Systematic and Evolutionary Biology 2 762-779.

Crozet N, Motlik J, Szöllösi D. 1981. Nucleolar fine structure and RNA synthesis in porcine oocytes during early stages of antrum formation. Biol Cel 41 35-42.

Daoud NM, Mahrous KF, Ezzo OH. 2012. Feed restriction as a biostimulant of the production of oocytes, their quality and GDF-9 gene expression in rabbit oocytes. Anim Reprod Sci 136 121-127. 
Denomme MM, Mann MRW. 2012. Genomic imprints as model for the analysis of epigenetic stability during assisted reproductive technologies. Reproduction 144 393-409.

Edwards LJ, McMillen IC. 2002. Impact of maternal undernutrition during the periconceptional period, fetal number, and fetal sex on the development of the hypothalamo-pituitary adrenal axis in sheep during late gestation. Biol Reprod 66 1562-1569.

Ernst CA, Rhees BK, Miao CH, Atchley WR. 2000. Effect of long-term selection for early postnatal growth rate on survival and prenatal development of transferred mouse embryos. J Reprod Fert 118 205-210.

Estany J, Baselga M, Blasco A, Camacho J. 1989. Mixed model methodology for the estimation of genetic response to selection in litter size in rabbit. Livest Prod Sci 21 67-76.

Estany J, Camacho J, Baselga M, Blasco A. 1992. Selection response of growth rate in rabbits for meat production. Genet Sel Evol 24 527-537.

Fortun-Lamothe L. 2006. Energy balance and reproductive performance in rabbit does. Anim Reprod Sci 93 1-15.

Friggens NC. 2003. Body lipid reserves and the reproductive cycle: towards a better understanding. Livest Prod Sci 83 219-236.

García-García RM, Rebollar PG, Arias-Álvarez M, Sakr OG, Bermejo-Álvarez P, Brecchia G, Gutierrez-Adan A, Zerani M, Boiti C, Lorenzo PL. 2011 . Acute fasting before conception affect metabolic and endocrine status without impacting follicle and oocyte development and embryo gene expression in the rabbit. Reprod Fertil Dev 23 759-768.

Godsen R, Krapez J, Briggs D. 1997. Growth and development of the mammalian oocyte. Bioessays 19 875-882.

Igosheva N, Abramov AY, Poston L, Eckert JJ, Fleming TP, Duchen MR, McConnell J. 2010. Maternal diet-induced obesity alters mitochondria activity and redox status in mouse oocytes and zygotes. PLoS One 5 el0074. 
Kwong WY, Wild AE, Roberts P, Willis AC, Fleming TP. 2000. Maternal undernutrition during preimplantation period of rat development causes blastocyst abnormalities and programming of postnatal hypertension. Development 127 4195-4202.

Leroy JLMR, Valckx SDM, Jordaens L, De Bie J, Desmet KLJ, Van Hoeck V, Brit† JH, Marei WF, Bols PEJ. 2015. Nutrition and maternal metabolic health in relation to oocyte and embryo quality: critical views on what we learned from the dairy cow model. Reprod Fertil Dev 27 693-703.

Luzzo KM, Wang Q, Purcell SH, Chi M, Jimenez PT, Grindler N, Schedl T, Moley KH. 2012. High fat diet induced developmental defects in the mouse: oocyte meiotic aneuploidy and fetal growth retardation/brain defects. PLoS One 7 e49217.

MacLaughlin SM, Walker SK, Roberts CT, Kleemann D, McMillen IC. 2005. Periconceptional nutrition and the relationship between maternal body weight changes in the periconceotional period and feto-placental growth in the sheep. J Physiol 565 111-124.

Mehaisen GMK, Vicente JS, Lavara R. 2004. In vivo embryo recovery rate by laparoscopic technique from rabbit does selected for growth rate. Reprod Dom Anim 39 347-351.

Mocé ML, Santacreu MA, Climent A, Blasco A. 2004. The effect of divergent selection for uterine capacity on fetal and placental development at term in rabbits: Maternal and embryonic genetic effects. J Anim Sci 82 1046-1052.

Naturil-Alfonso C, Marco-Jiménez F, Jiménez-Trigos E, Saenz-de-Juano MD, Viudes-de-Castro M, Lavara R, Vicente J. 2015. Role of Embryonic and Maternal Genotype on Prenatal Survival and Foetal Growth in Rabbit. Reprod Domest Anim 50 312-320.

Parr RA, Davis IF, Fairclough RJ, Miles MA. 1987. Overfeeding during early pregnancy reduces peripheral progesterone concentration and pregnancy rate in sheep. J Reprod Fert 80 317-320. 
Pascual JJ, Castella F, Cervera C, Blas E, Fernández-Carmona J. 2000. The use of ultrasound measurement of perirenal fat thickness to estimate changes in body condition of young female rabbits. Anim Sci 70 435-442.

Petrere JA, Rohn WR, Grantham II LE, Enderson JA. 1993. Food restriction during organogenesis in rabbits: effects on reproduction and the offspring. Fundame Appl Toxicol 21 517-522.

Picone O, Laigre P, Fortun-Lamothe L, Archilla C, Peynot N, Ponter AA, Berthelot V, Cordier AG, Duranthon V, Chavatte-Palmer P. 2011. Hyperlipidic hypercholesterolemic diet in prepubertal rabbits affects gene expression in the embryo, restricts fetal growth and increases offspring susceptibility to obesity. Theriogenology 75 287-299.

Robker R. 2008. Evidence that obesity alters the quality of oocytes and embryos. Pathophysiology $15115-121$.

Rommers JM, Meijerhoft R, Noordhuizen JP, Kemp B. 2002. Relationships between body weigth at first mating and subsequent body development, feed intake, and reproductive performance of rabbit does. J Anim Sci 80 2036-2042.

Saitou M, Kagiwada S, Kurimoto K. 2012. Epigenetic reprogramming in mouse pre-implantation development and primordial germ cells. Development 13915 31.

Sánchez JP, de La Fuente LF, Rosell JM. 2012. Health and body condition of lactating females on rabbit farms. J Anim Sci 90 2353-2361.

Theilgaard P. 2006. Prolificacy, reproductive longevity and body reserves in female rabbits examined using selection lines. Ph.D. Thesis. Universitat Politècnica de València. Spain; pp. 126.

Tripp MW, Ju JC, Hoagland TA, Riesen JW, Yang X, Zinn SA. 2000. Influence of somatotropin and nutrition on bovine oocyte retrieval and in vitro development. Theriogenology 53 1581-1590.

Vicente JS, Llobat L, Viudes-de-Castro MP, Lavara R, Baselga M, MarcoJiménez F. 2012. Gestational losses in a rabbit line selected for growth rate. Theriogenology 77 81-88. 
Vicente JS, Llobat L, Jiménez-Trigos E, Lavara L, Marco-Jiménez F. 2013a. Effect of emrbyonic and maternal genotype on embryo and foetal survival in rabbit. Repro Dom Anim 48 402-406.

Vicente JS, Saenz-de-Juano MD, Jiménez-Trigos E, Viudes-de-Castro MP, Peñaranda DS, Marco-Jiménez F. 2013b. Rabbit morula vitrification reduces early foetal growth and increases losses throughout gestation. Criobiology 67 321-326.

Viudes-de-Castro MP, Vicente JS. 1997. Effect of sperm count on the fertility and prolificity traits of meat rabbits. Anim Reprod Sci 46 313-9.

Wakefield SL, Lane M, Schulz SJ, Hebart ML, Thompson JG, Mitchell M. 2008. Maternal supply of omega-3 polyunsaturated fatty acids alter mechanisms involved in oocyte and early embryo development in the mouse. Am J Physiol Endocrinol Metab 294 E425-E434.

Watkins AJ, Ursell E, Panton R, Papenbrock T, Hollis L, Cunningham C, Wilkins A, Perry VH, Sheth B, Kwong WY, Eckert JJ, Wild AE, Hanson MA, Osmond C, Fleming TP. 2008. Adaptative response by mouse early embryos to maternal diet protect fetal growth but predispose to adult onset disease. Biol Reprod 78 299-306.

Xiccato,G Trocino A. 2010. Energy and Protein Metabolism and Requirements. In: de Blas C, Wiseman J (ed), Nutrition of the Rabbit $2^{\text {nd }}$ edition. CABI, Wallingford, UK, pp. 83-118.

Wilmut I, Sales DI, Ashowrth CJ. 1986. Maternal and embryonic factors associated with prenatal loss in mammals. J Reprod Fert 76 851-864.

Wilson ME, Ford SP. 1997. Differences in trophoectoderm mitotic rate and P450 17a-hydroxylase expression between late preimplantation Meishan and Yorkshire conceptuses. Biol Reprod 56 380-385.

Wu LL, Russell DL, Wong SL, Chen M, Tsai TS, St John JC, Norman RJ, Febbraio MA, Carroll J, Robker RL. 2015. Mitochondrial dysfunction in oocytes of obese mothers: transmission to offspring and reversal by pharmacological endoplasmic reticulum stress inhibitors. Development $142 \quad 681-691$ 


\section{CHAPTER FIVE}

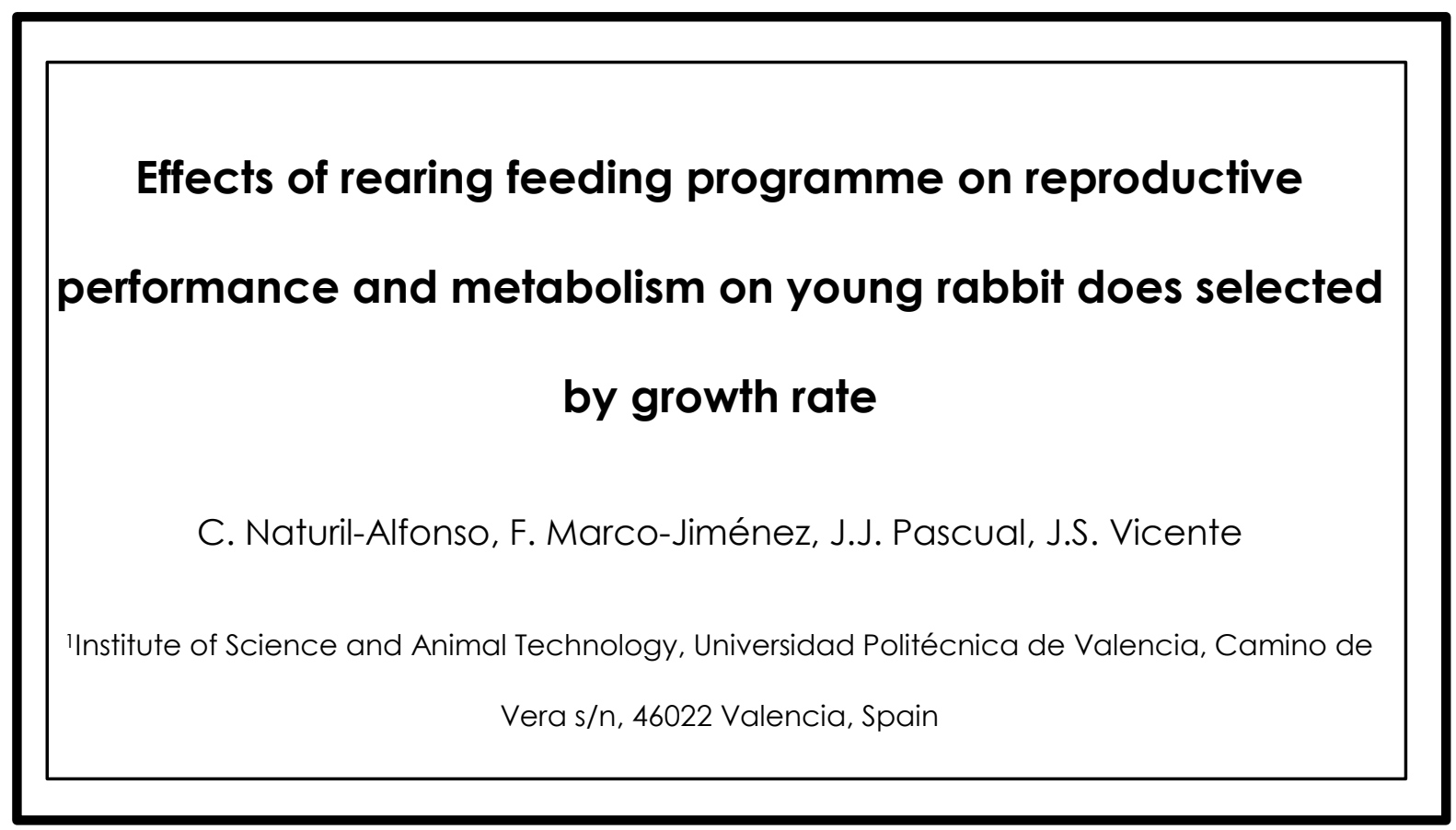

This work was supported by the Spanish Research Project AGL2014- 53405-C2-1-P (CICYT). Carmen Naturil was supported by a research grant from the Education Ministry of the Valencian Regional Government (programme VALi+d. ACIF / 2013 / 296). 



\section{ABSTRACT}

Several reports have established that different maternal feeding regimes prior to mating could modify reproductive performance. This study evaluated the effect of two different feeding regimes from 16 weeks of age to third parity on feed intake, body weight and composition, metabolic and hormone parameters (leptin, NEFA, BOHB, fructosamine) and reproductive performance in rabbit does selected for growth rate. Twenty-four 16-week-old does were randomly distributed in two groups: restricted (130g/day) or ad libitum (235.5g/day) fed. One month later, the does were artificially inseminated (Al). Measurements of weight, perirenal fat thickness, leptin, Non-Esterified-FattyAcids (NEFA), beta-hydroxybutyrate (BOHB) and fructosamine were performed at $\mathrm{Al}$, parity and weaning. Fertility, prolificacy, productivity and litter size at parity were recorded. Ad libitum females were heavier than restricted does in the 1st reproductive cycle, although without differences in perirenal fat thickness. However, differences disappeared in posterior cycles. Differences were also found in NEFAs and BOHB concentrations. However, no differences were found in global reproductive performance in terms of fertility, prolificacy and productivity between groups. Therefore, different rearing regimes until first Al in females selected by growth rate had no effect on their reproductive outcomes, as the reproductive performance was not improved during and after three reproductive cycles. 



\section{INTRODUCTION}

Paternal lines are selected for post-weaning daily weight gain (Estany et al., 1992). These lines are essential in rabbit farm production as they are employed as terminal sires in the three-way cross scheme in order to obtain crossbred animals with both reproductive and growth traits to produce larger number of rabbits with fast growth and high feed efficiency (Baselga, 2004). Despite the relevance of growth rate, the efficiency and profitability of rabbit meat production depends on reproductive success, defined by fertility and litter size (Piles et al., 2005). Unfortunately, long-term selection for growth rate traits can result in physiological, immunological and/or reproductive problems (Rauw et al., 1998). Piles and Tusell (2011) founded that the genetic correlation between average daily weight and reproductive traits in female is negative but low in magnitude: selection for growth traits could produce a slightly negative effect in fertility of paternal lines. However, other studies have shown that ovulation rate and litter size increase with the body weight of the doe in different breeds of rabbits ranging from 1.2 to $6 \mathrm{~kg}$ (Bünger et al., 2005), which suggests a positive relationship between body weight and litter size (Mgheni and Christensen, 1985; Camacho and Baselga, 1990). Therefore, genetic correlations between growth and reproductive traits in rabbits are contradictory, perhaps due to the genetic line and the reproductive characteristic studied (Camacho and Baselga, 1990; Rochambeau et al., 1994; Gómez et al., 1998; Garreau et al., 2000; García and Baselga, 2002).

Line $R$ is a rabbit synthetic line created in 1990 selected by individual selection criterion of daily weight gain from weaning (28 days) to slaughter age (63 days, Estany et al., 1992). The main objective was to improve the feed efficiency, 
because of its negative and important genetic correlation between growth rate and conversion index (Blasco, 1989). After 36 generations, line $R$ has shown severe reproductive problems such as ovulation failure, implantational embryo failure and lesser litter size, related with higher implantational, gestational and fetal losses (Vicente et al., 2010; 2012; Naturil-Alfonso et al., 2015).

The reproductive performance of animals could be affected by their feeding regimen and consequently, their nutritional balance (Wolfenson and Blum, 1988; Fortun-Lamothe, 2006). Several reports have established that an altered maternal nutritional regimen prior to mating and during pre-implantation development can influence follicular/oocyte characteristics and embryo development (Edwards and McMillen, 2002; MacLaughlin et al., 2005; Watkins et al., 2008; Picone et al., 2011; Daoud et al., 2012). In this sense, a restrictive diet during rearing is used to control body condition and prevent the negative effects of overfattening on fertility and fetal losses (Rommers et al., 2004). However, an ad libitum diet provides better sexual development, in terms of receptivity, ovulation rate, blastocyst size and implantation rate, even containing more fat (Ashworth et al., 1999a,b; Rommers et al., 2004). Thus, our hypothesis was that the nutritional regimen is not enough to cope with the needs during reproduction of these females, which are selected for growth rate over 36 generations, causing a long-term nutrient deficiency which leads to the subsequent reproductive problems.

The aim of this study was to evaluate the influence of two different rearing feeding strategies (restricted and ad libitum) from rearing to first insemination on reproductive performance, body composition and circulating metabolic hormones and metabolites in a rabbit line selected by growth rate. 


\section{MATERIAL AND METHODS}

All chemicals used in this study were purchased from Sigma-Aldrich Química S.A. (Madrid, Spain) unless stated otherwise.

\section{Ethical Statement}

The experiment was performed in accordance with the principles of animal care published by Spanish Royal Decree 53/2013 (BOE 2013). The animal studies were approved by the Committee of Ethics and animal Welfare of the Universidad Politécnica de Valencia (procedure 2015/vsc/00061). Researchers involved in the work with the animals held an animal experimentation license issued by the Spanish authorities.

\section{Animals}

The animals used in this study came from a synthetic rabbit line selected for growth rate between weaning and slaughter time (9th weeks of life) for 36 generations at the experimental farm from the Universidad Politécnica de Valencia (Estany et al., 1992). Twenty-four females were housed individually at 12 weeks of age, with free access to water, under a 16-hour light/8-hour dark photoperiod unless stated below.

At four months of age, females were divided in two experimental groups: feeding restricted ( $n=13$; provided daily with $130 \mathrm{~g} /$ day to comply with energy requirements for maintenance: 340 kJ day-1 kg-1 LW0.75; Xiccato and Trocino 2010) or ad libitum ( $n=11)$. Rabbits were fed with a commercial rabbit diet (on dry matter basis: $17.5 \%$ crude protein, $3.5 \%$ ether extract, $16.7 \%$ crude fibre, $2938 \mathrm{kcal} / \mathrm{kg}$ ). After one month under these experimental conditions, females were reproduced. The feed intake of ad libitum does was determined by 
weighing the feeder at the beginning and end of each week, and all feed supplies given within a week were recorded. Additionally, when a restricted doe was tested as pregnant, the diet was established as an ad libitum regime.

\section{Reproductive traits}

A total of 24 does (13 restricted and 11 ad libitum) were used in this study. The reproductive period included the first three parities of each doe until weaning of the third litter.

Receptivity of does was determined observing the vulvar colour and turgescence, considering receptive those with red/purple and swollen vulva. Artificial insemination (Al) was performed with $0.5 \mathrm{~mL}$ of fresh heterospermic pool of males from the same line selected with motility criteria and diluted 1:5 with tris-citric-glucose diluent (Viudes-de-Castro and Vicente, 1997). Immediately after insemination, ovulation was induced by an intramuscular injection of $1 \mu \mathrm{g}$ of Buserelin Acetate (Suprefact, Hoescht Marion Roussel, S.A., Madrid, Spain).

Fertility was assessed at Day 14 post-insemination by ultrasound examination by a portable colour Doppler ultrasound device (Esaote, Spain) with 7.5 MHz linear probe (4-12 MHz range). Prior to examination, does were anaesthetized with ketamine 35 and xylazine $16 \mathrm{mg} / \mathrm{kg}$ intramuscularly and the abdomen of the doe was clipped. Does were placed in a polystyrene cage where they were prevented from moving. The ultrasound examination was performed from right to left with the probe in sagittal orientation for identification of the fetal sacs. Five days before parturition, each doe had free access to a nestbox that was put in front of the cage. At parturition, litter size was recorded. Nestboxes were 
removed 3 weeks later and kits were placed in the cage with the doe to stimulate solid-feed intake. Weaning was performed $30 \mathrm{~d}$ post-partum. The number of kits at weaning was also noted. Second and third inseminations were performed 12 days post-kindling (semi-intensive breeding rhythm). Nonpregnant does were inseminated 21 days after the previous one. Does not pregnant after two successive inseminations were excluded from the experiment

Fertility, prolificacy and productivity were evaluated at the end of the three reproductive cycles. Fertility rate was calculated for each group (ad libitum or restricted) as the number of does that kindled after insemination compared to the number of inseminations performed. Prolificacy was determined per female as the total number of born kits compared to the total number of inseminations. Productivity was calculated per female as the total number of born kits compared to the total number of inseminations.

\section{Body condition}

Body weight and body composition of rabbit does were determined at Al, parity and weaning over 3 reproductive cycles. The perirenal fat thickness (PFT) of does was measured by ultrasound to evaluate body condition, as described by Pascual et al., (2000a). Briefly, images were obtained with the portable colour Doppler ultrasound device stated above. PFT measures were indirectly obtained using the ultrasound unit software. When measuring the PFT, does were also weighed.

\section{Collection of blood samples}

Blood samples were taken at the moment of Al, parity and weaning. They were obtained from the central ear artery into EDTA-coated tubes and immediately 
centrifuged at $3000 \times \mathrm{g}$ for 10 minutes and were stored at $-20^{\circ} \mathrm{C}$ until analysis. Samples were taken twice for each female to determine the profile of NEFA (non-esterified fatty acids), leptin, BOHB (beta-hydroxybutyrate: ketone bodies) and fructosamine concentration.

\section{Metabolites assay}

Samples were analysed for leptin, non-esterified fat acids (NEFA), fructosamine, beta-hydroxybutyrate (BOHB) and glucose. Leptin was analysed by Multispecies Leptin assay (RIA, XL-85K) (Milipore Corporation, Billerica, MA, USA), according to the manufacturer's guidelines. Intra- and inter-assay CV were 9.1\% and 9.3\%, respectively. NEFAs were determined using the NEFA C ACSACOD assay method (Wako Chemicals GmbH, Neuss, Germany). Serum levels of fructosamine were assessed by a colorimetric assay (Roche Diagnostics). $\mathrm{BOHB}$ was determined as an increase in absorbance at $340 \mathrm{~nm}$ owing to the production of $\mathrm{NADH}$, at slightly alkaline $\mathrm{pH}$ in the presence of $\mathrm{BOHB}$ dehydrogenase. Sample blanks were included and the method involved oxamic acid in the media to inhibit lactate dehydrogenase, as proposed by Harano et al., (1985). Analyses of NEFA, BOHB and glucose were performed using an auto-analyser, ADVIA 1650® Chemistry System 8Siemens Medical Solutions, Tarrytown, NY, USA); in all instances, the intra- and inter-assay CV was below $2 \%$ and $4 \%$, respectively.

\section{Statistical analysis}

To compare fertility between groups, a general linear model was performed including the type of feeding with two levels (ad libitum or restricted) as a fixed factor. The error was designated as having a binomial distribution using the probit link function. Binomial data for fertility were assigned a value of one if Al 
was positive. Failure to inseminate resulted in a score of zero. Prolificacy and productivity differences between groups were analysed with a generalized linear model including the type of feeding with two levels (ad libitum and restricted) as a fixed effect.

The model used to analyse litter size and metabolic data at artificial insemination, partum and weaning during first, second and three or more reproductive cycles was a mixed model (PROC MIXED by Statistical Analysis System, SAS, 2002), in a repeated measure design that took into account the variation between animals and the covariation within them. Covariance structures were objectively compared using the most severe criteria (Schwarz Bayesian criterion), as suggested by Littell et al., (1998). The model included the feeding programme (ad libitum or restricted), the moment (Al, partum or weaning) and their interaction as fixed effects. Random terms in the model included a permanent effect of each animal (p) and the error term (e), both assumed to have an average of zero and variance $\sigma 2 p$ and $\sigma 2 e$, respectively. Different contrasts were computed to test the significance of the differences between feeding regimens.

Differences of $p<0.05$ were considered significant. Data are shown as means \pm standard error means (S.E.M.). All analyses were performed with SPSS 16.0 software package (SPSS Inc., Chicago, Illinois, USA, 2002).

\section{RESULTS}

\section{Reproductive performance}

Donor females fed ad libitum showed significantly increased ingestion of $55 \%$ compared to the restricted group (235.5 $\pm 6.87 \mathrm{~g} /$ day vs. $130.0 \mathrm{~g} / \mathrm{day})$. 
No significant differences were found in fertility rate, prolificacy and productivity between restricted and ad libitum females at the end of the established reproduction period. However, average fertility rate of the three reproductive cycles was higher in ad libitum females, as more than half of these females became pregnant, while less than half of the restricted females did so ( $0.56 \pm 0.085$ vs. $0.43 \pm 0.073$ for ad libitum and restricted females, respectively) Average prolificacy of the three productive cycles was similar for both groups (7.2 \pm 0.54 and $7.7 \pm 0.54$ for restricted and ad libitum females, respectively) while productivity was $5.0 \pm 0.94$ for restricted females and $6.6 \pm 1.00$ for ad libitum ones.

Figure 5.1 shows the effect of the feeding programme on litter size of different parturitions. Differences were only detected at second kindling, where ad libitum females showed higher litter size than restricted ones (8.6 \pm 0.90 vs. $6.0 \pm$ 1.14 , respectively).

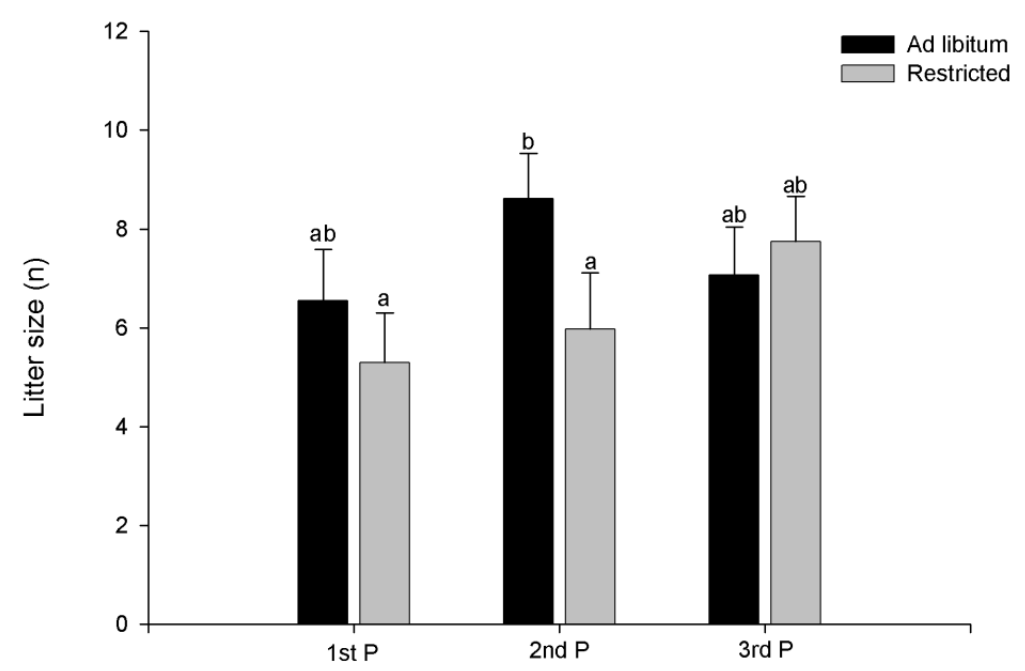

Figure 1.1. Litter size for ad libitum and restricted females. Bars show the mean value \pm SEM of the females involved in each group. Bars with different superscripts are significantly different $(p<0.05)$. 


\section{Body condition}

Ad libitum females showed to be heavier during almost the entire reproductive cycle at the different 1st, 2nd and 3rd cycles (Figure 5.2). Interestingly, at the moment of artificial insemination, ad libitum does were heavier at first and second reproductive cycles, while at third Al body weight was similar between groups. In fact, during the first reproductive cycle differences in body weight diminished and had already disappeared by the 3rd cycle (Figure 5.2).

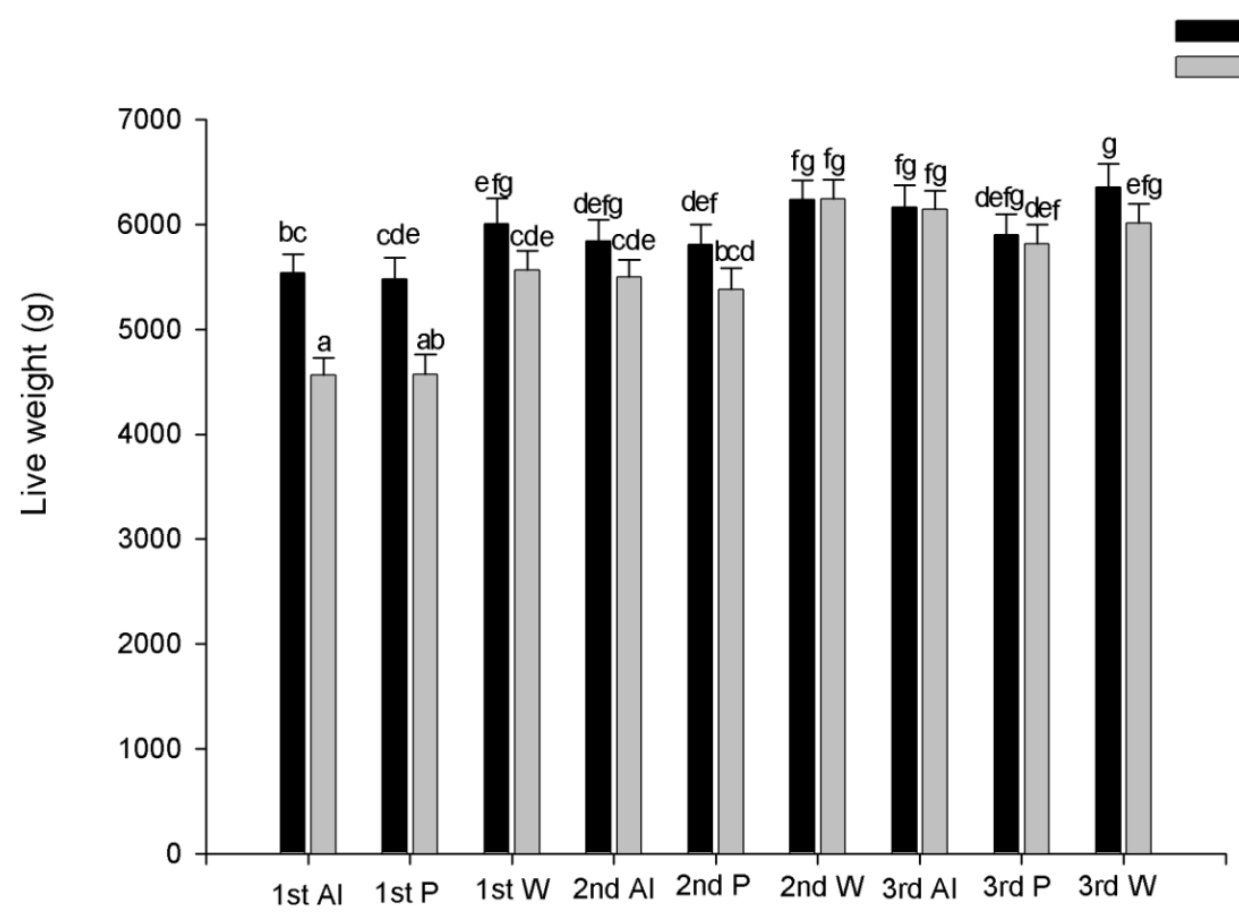

Figure 5.2. Live body weight evolution of females at artificial insemination (Al), parturition (P) and weaning (W) at different reproductive cycles (first: 1st; second: 2nd; and third or posterior: 3 rd). Bars with different superscripts are significantly different $(p<0.05)$.

However, those ad libitum females with higher body weight at 1st Al were those which did not get pregnant (Table 5.1). 
Table 5.1. Effect of an ad libitum or restricted diet during rearing and Al success (pregnant status) on body condition.

\begin{tabular}{|l|c|c|}
\hline \multicolumn{1}{|c|}{ Type } & Weight & Perirenal fat (mm) \\
\hline Ad libitum/pregnant & $5048.00 \pm 123.15^{\mathrm{a}}$ & $9.36 \pm 0.38$ \\
\hline Ad libitum/non-pregnant & $5474.17 \pm 112.42^{\mathrm{b}}$ & $9.01 \pm 0.35$ \\
\hline Restricted/pregnant & $4487.14 \pm 104.08^{\mathrm{c}}$ & $8.63 \pm 0.32$ \\
\hline Restricted/non-pregnant & $4611.67 \pm 112.42^{\mathrm{c}}$ & $8.71 \pm 0.35$ \\
\hline
\end{tabular}

Al: artificial insemination. Means in the same arrow with different letters show significant differences between female groups $(p<0.05)$.

In contrast, no significant differences were observed for perirenal fat thickness between ad libitum and restricted females (Figure 5.3). Thus, when PFT was analysed for ad libitum and restricted females at different reproductive cycles and moments (Al, kindling and weaning), significant differences were only found at first Al $(9.36 \pm 0.29 \mathrm{~mm}$ vs. $8.7 \pm 0.27 \mathrm{~mm}$, for ad libitum and restricted females, respectively). Additionally, the reduction in PTF at first partum is higher in ad libitum females (-0.68) than in restricted ones (-0.44) (Figure 5.3). Moreover, differences in PTF fluctuations are also observed in the second cycle, with high differences between Al, partum and weaning in restricted females, while PTF of ad libitum females remained constant. 


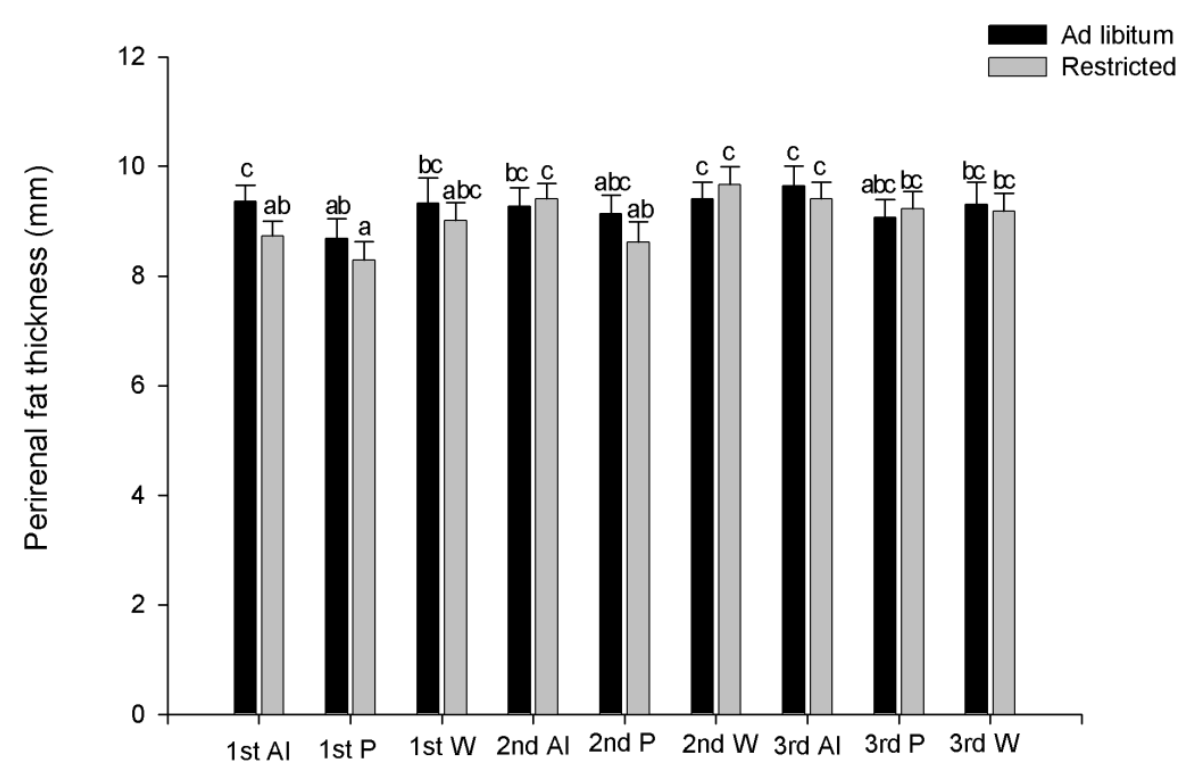

Figure 5.3. Perirenal fat thickness evolution of females at artificial insemination (Al), parturition (P) and weaning (W) at different reproductive cycles (first: 1st; second: 2nd; and third or posterior: 3rd). Bars with different superscripts are significantly different $(p<0.05)$.

\section{Blood metabolites parameters}

The plasma profile of leptins, NEFAs, fructosamine and BOHB are shown in Figure 5.4. When metabolites were analysed for restricted and ad libitum females, small differences were found. Circulating leptin levels at 3rd reproductive cycle were shown to be reduced at $\mathrm{Al}$ and parturition in restricted females compared with levels from ad libitum females $(-0.24 \mathrm{ng} / \mathrm{mL}$ and $-0.31 \mathrm{ng} / \mathrm{mL}$ at $\mathrm{Al}$ and partum, respectively, Figure 5.4A).

NEFAs plasma concentrations showed to be different between females from different feeding regimens only at 1 st and 2 nd parturition. Ad libitum females showed higher levels of NEFAs than restricted ones (Figure 5.4B). Moreover, females overlapping suckling and gestation presented higher NEFAs plasma concentrations (Figure 5.4B). 
A
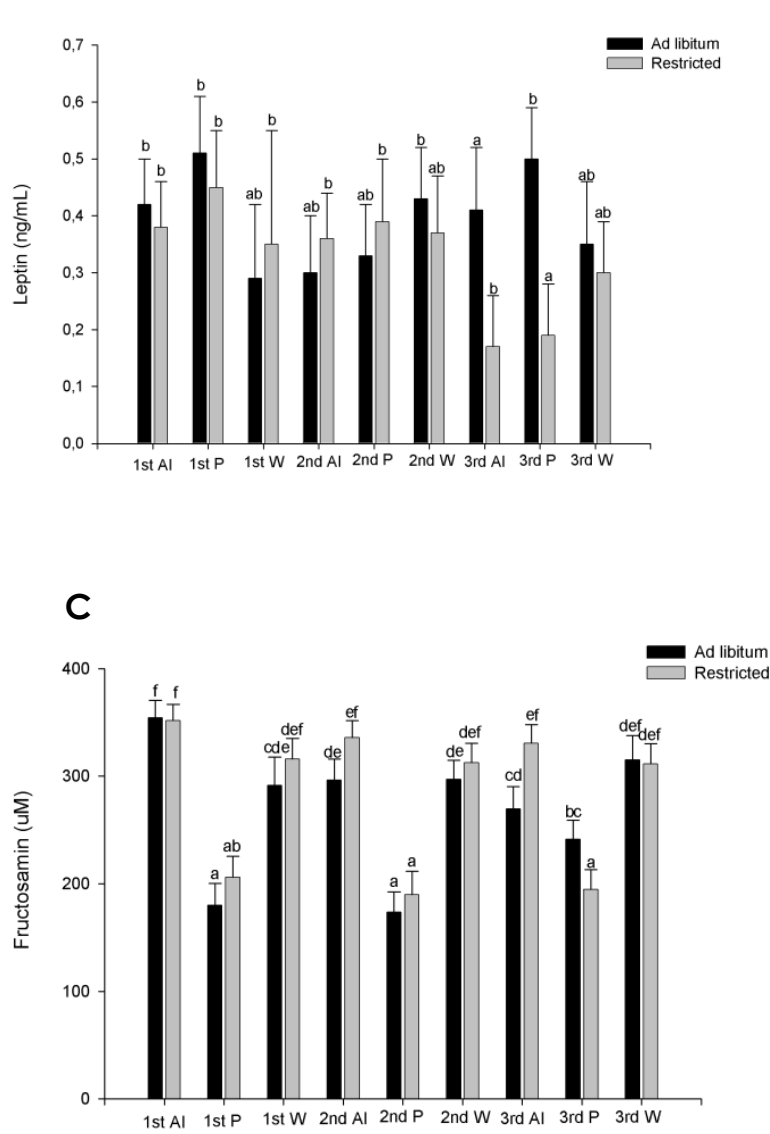

B

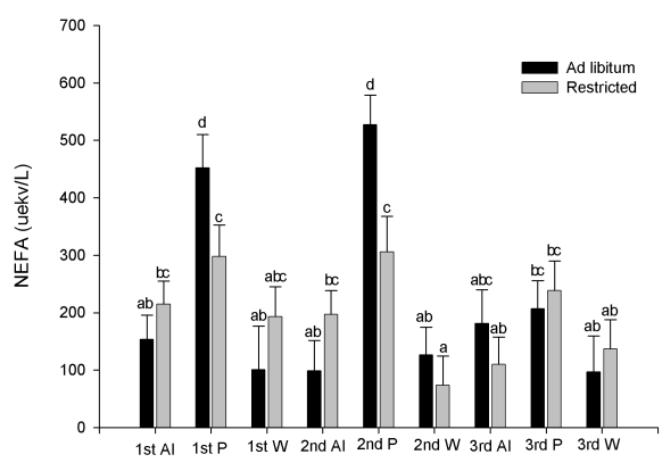

D

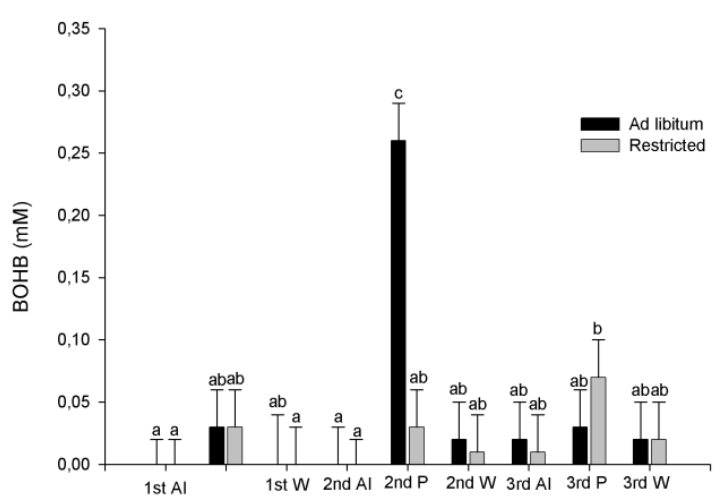

Figure 5.4. Evolution of blood plasma (A) leptin, (B) non-esterified fatty acids (NEFA), (C) fructosamine and (D) beta-hydroxybutyrate concentrations in females at artificial insemination (Al), parturition (P) and weaning (W) at different reproduction cycles (first: 1st; second: 2nd; and third or posterior: 3rd). Bars with different superscripts are significantly different $(p<0.05)$.

Fructosamine plasma levels are shown in Figure 5.4C. No differences are found at any time between ad libitum and restricted females except at $3 \mathrm{rd} \mathrm{Al}$ and partum. At 3rd Al ad libitum females showed lower levels of plasma fructosamine $(269.6 \pm 21.0 \mu \mathrm{M}$ vs. $330.6 \pm 17.4 \mu \mathrm{M}$, for ad libitum and restricted females, respectively). However, at 3rd kindling fructosamine plasma concentration was higher in ad libitum females than in restricted ones (241.4 \pm $17.9 \mu \mathrm{M}$ vs. $194.9 \pm 18.2 \mu \mathrm{M}$, for ad libitum and restricted females, respectively). On the other hand, the highest levels of plasma fructosamine for both ad 
libitum and restricted females were detected at 1st Al, while the lowest levels were detected at partum (Figure 5.4C).

Levels obtained for plasma BOHB concentrations are generally too low for detection. Only at kindling levels were high enough to allow measurements. Specifically, only differences were found at 2nd partum (Figure 5.4D). At this point ad libitum females showed higher levels of BOHB plasma concentration than restricted does $(0.26 \pm 0.03 \mathrm{mM}$ vs. $0.03 \pm 0.03 \mathrm{mM}$, for ad libitum and restricted females, respectively).

\section{DISCUSSION}

The relationship between nutrition and reproduction has been observed for several decades (Fortun-Lamothe, 2006). Previous studies have demonstrated that the nutritional regimen before and after mating influences the profile of circulating concentrations of metabolites and reproductive hormones, such as glucose, NEFA, leptin, insulin and IGF-I, which could determine reproductive performance (Ferguson et al., 2003; Brecchia et al., 2006; García-García et al., 2011). Our results confirm this effect of nutritional regimen on metabolic alterations in different ways, but did not show any effect on reproductive efficiency of $R$ line (paternal line).

Our results revealed that ad libitum females were heavier throughout the reproductive period studied, as a consequence of the higher feed intake. The higher body weight at first $\mathrm{Al}$ remained during the reproductive period, but as Rommers et al. (2004) appreciated, the difference was compensated between groups until it finally disappeared in the 3rd reproductive cycle. Several works have shown that selection for growth traits results in heavier animals with negative responses in reproduction performance (Mgheni and Christensen, 
1985; Arias-Álvarez et al., 2009; Gómez et al., 1999; Ragab et al., 2010). Maybe this fact meant that ad libitum does with excess body weight at first Al were those which did not get pregnant. However, another possibility is that the selection process influences maturation process and genotypes, and these animals could present a lower degree of physiological maturation, which would explain at least some of the reproductive failures.

Interestingly, the higher weight of ad libitum females is not indicative of overfat females, as no differences in PFT were detected between females fed with different rearing strategies. Differences in PFT were only significant at 1st Al. As previously observed by Martínez-Paredes et al. (2012), at 1st Al ad libitum females presented higher PFT, probably as a consequence of higher feed intake, but these differences disappeared at 1st kindling. Nevertheless, during the second reproductive cycle higher fluctuations were observed in restricted females between the different moments analysed. These fluctuations are indicative of higher pre-partum fat mobilization with negative consequences on litter size. At 2nd partum, restricted females presented the lowest litter size. This appreciation is contrary to other results in rabbit paternal lines which did not find effects of feed restriction on litter size when analysing until 4th parturition (Verdelhan et al., 2005). Thus, metabolite analysis would help to understand if reduction in litter size at second partum was a direct effect of different feeding regimes or just a chance effect.

The differences in body weight, PFT and litter size in the second reproductive cycle between ad libitum and restricted females were also manifested in plasma metabolite concentrations, specifically in NEFAs and BOHB levels. NEFA concentrations at kindling are the highest, indicating high reserve mobilizations 
due to the body fat transfer to the fetuses during the last week of pregnancy, causing a NEB in the mother (Rommers et al., 2004). At 2nd kindling, NEFA plasma concentrations were higher in ad libitum females than in restricted ones, which may be related with the higher litter size in these females (+3.3). The higher number of kits would increase the needs of milk production and consequently present higher reserve mobilizations (Pascual et al., 2000b; Pascual et al., 2002), which was reflected in higher blood concentrations of NEFAs (Savietto et al., 2014).

Similar to the NEFA results, plasma BOHB concentration were higher in ad libitum females than in restricted ones at 2 nd partum. These higher levels of BOHB might be indicative of the energy effort of the females to cope with the high energetic needs due to the litter size in this parturition (8.6, when the average was 6.8). On the other hand, $\mathrm{BOHB}$ levels were only able to be detected at parturitions, when the highest reserve mobilizations take place (Pascual et al., 2013).

In this work, we chose fructosamine as a parameter to evaluate glucose variations, as it is a more stable indicator of short-term glycaemic status, which reflects the average glucose levels for the previous 10-14 days (True, 2009). Although body weight results seemed to indicate a severe restriction in restricted females, results did not reveal any difference in plasma fructosamine concentrations between females from different feeding regimens in the 1st and 2nd reproductive cycles. These results indicated that the restriction was not too severe and restricted females had sufficient energy. However, at 3rd kindling and weaning ad libitum females had higher levels of blood fructosamine. The higher number of kits in the second kindling might induce a higher feed intake 
post-weaning due to the higher suckling needs (Pascual et al., 2002), which would in turn be reflected in the increase in blood fructosamine concentration.

It is also at 3rd reproductive cycle when differences between groups in plasma leptin concentrations are found. The lower leptin concentration in restricted females might be indicating that restricted females reach $3 \mathrm{rd}$ and subsequent reproductive cycles with lower body energy reserves, which may reflect female depletion. However, no differences were detected either in body weight or in PTF between females from both groups. Thus, lower leptin concentration in 3rd and subsequent cycles may be a consequence of higher overlapping between gestation and weaning. Moreover, the lower litter size at 2nd partum in restricted females may lead to a lower feed intake due to lower milk production needs, with a consequent drop in leptin levels.

Therefore, few differences were found at metabolic levels between females fed ad libitum or restricted from rearing to reproduction, with no significant effects on reproductive performance. Differences were mainly detected in the 1st reproductive cycle, which seemed to be compensated at later parturitions $(\geq 3)$.

In our previous study, the feeding regimen showed a significant effect on embryonic quality, increasing the number of kits born when embryos came from an ad libitum fed donor female (Naturil-Alfonso et al., 2016). Based on these results, we hypothesized that the nutritional regime is not enough to cope with the needs during reproduction of those females which are selected for growth rate. Needs were established from the equation proposed by Xiccato and Trocino (2010): 340 kJ day-1 kg-1 LW0.75, so the nutritional requirements for these females were previously established as $130 \mathrm{~g} /$ day with a commercial 
rabbit diet on dry matter basis: $17.5 \%$ crude protein, $3.5 \%$ ether extract, $16.7 \%$ crude fibre, $2938 \mathrm{kcal} / \mathrm{kg})$. However, after 36 generations of selection, the nutritional needs of these females for reproductive could have changed. Nevertheless, the different feeding regimen strategies (restricted and ad libitum) during the rearing period of young rabbit females selected for growth rate did not induce changes in their productive life performance. On the other hand, physiological mature degree or genotypes might have been modified through the selection process.

In the light of these results, other different strategies should be carried out. Generally, heavy animals with lower productivity need a low metabolic effort. In these animals, metabolic effort is only determinant at first gestation, but mainly at second parturition, as in other rabbit lines, when lactation and gestation are overlapped, as can be appreciated in the fluctuations detected in this study (LS, NEFAs and BOHB). Therefore, further studies testing other nutritional and rearing strategies, such as a feeding strategy at these particular times, should be carried out.

\section{REFERENCES}

Arias-Álvarez M, García-García RM, Rebollar PG, Nicodemus N, Revuelta L, Millán P, Lorenzo PL. 2009. Effects of a lignin-rich fiber diet on productive, reproductive and endocrine parameters in nulliparous rabbit does. Livest Sci 123 107-115.

Asworth CJ, Antipatis C, Beattie L. Effects of pre- and post-mating nutritional status on hepatic function, progesterone concentration, uterine protein secretion and embryo survival in Meishan pigs. Reproduction, Fertility and Development 1999a 11 67-73. 
Asworth CJ, Beattie L, Antipatis C, Vallet J. Effects of pre- and postmating feed intake on blastocyst size, secretory function and glucose metabolism in Meishan gilts. Reproduction, Fertility and Development 1999b 11 323-327.

Baselga M. 2004. Genetic improvement of meat rabbits. Programmes and diffusion. In: Proc. 8th World Rabbit Congress, Puebla, Mexico, 1-13.

Blasco A. 1989. Genética y nutrición del conejo. In C. de Blas Alimentación del conejo. Ediciones Mundi,Prensa, Madrid.

Brecchia G, Bonanno A, Galeati G, Federici C, Maranesi M, Gobbetti A, Zerani M, Boiti C. Hormonal and metabolic adaptation to fasting. 2006. Effects on the hypothalamic-pituitary-ovarian axis and reproductive performance of rabbit does. Domestic Animal Endocrinology 31 105-122.

Bünger L, Lewis RM, Rothschild MF, Blasco A, Renne U, Simm G. 2005. Relationships between quantitative and reproductive fitness traits in animals. Phil Trans R Soc B 360 1489-1502.

Camacho J, and Baselga M. 1990. Genetic correlation between reproductive and growth traits in rabbits. In Proc: 4th World Congress on Genetics Applied to the Livestock Production, Edinburgh, Scotland 16:366-369.

Daoud NM, Mahrous KF, Ezzo OH. 2012. Feed restriction as a biostimulant of the production of oocytes, their quality and GDF-9 gene expression in rabbit oocytes. Anim Reprod Sci 136 121-127.

Edwards LJ, McMillen IC. 2002. Impact of maternal undernutrition during the periconceptional period, fetal number, and fetal sex on the development of the hypothalamo-pituitary adrenal axis in sheep during late gestation. Biology of Reproduction 66 1562-1569.

Estany J, Camacho J, Baselga M, Blasco A. 1992. Selection response of growth rate in rabbits for meat production. Genet Sel Evol 24 527-537.

Ferguson EM, Ashworth CJ, Edwards SA, Hawkins N, Hepburn N, Hunter MG. 2003. Effect of different nutritional regimens before ovulation on plama 
concentrations of metabolic and reproductive hormones and oocyte maturation in gilts. Reproduction 126 61-71.

Fortun-Lamothe L. 2006. Energy balance and reproductive performance in rabbit does. Animal Reproduction Science 93 1-15.

García ML, Baselga M. 2002. Estimation of correlated response on growth traits to selection in litter size of rabbits using a cryopreserved control population and genetic trends. Livestock Production Science 78 91-98.

García-García RM, Rebollar PG, Arias-Álvarez M, Sakr OG, BermejoÁlvarez P, Brecchia G, Gutierrez-Adan A, Zerani M, Boiti C, Lorenzo PL. 2011. Acute fasting before conception affects metabolic and endocrine status without impacting follicle and oocyte development and embryo gene expression in the rabbit. Reprod Fertil Dev 23 759-768.

Garreau H, Szendro ZS, Larzul C, Rochambeau H. 2000. Genetic parameters and genetic trends of growth and litter size traits in the white Pannon breed. In Proc. 7th World Rabbit Congress, Valencia, Spain.

Gomez EA, Rafel O, Ramon J. 1998. Genetic relationships between growth and litter size traits at first parity in a specialized dam line. In Proc. 6th World Congress on Genetics Applied to Livestock Production, Armidale, Australia. 25.

Gómez AE, Baselga M, Rafel O, García ML, Ramón J. 1999. Selection, diffusion and performances of six Spanish lines of meat rabbit. Cahiers Options Méditerranéennes 41 147-152.

Littell RC, Henry PR and Ammerman CB. 1998. Statistically analysis of repeated measures data using SAS procedures. Journal of Animal Science 76, 1216-1231.

Martínez-Paredes E, Ródenas L, Marínez-Vallespín B, Cervera C, Blas E, Brecchia G, Boiti C, Pascual JJ. 2012. Effects of feeding programme on the performance and energy balance of nulliparous rabbit does. Animal 6, 10861095. 
McLaughlin SM, Walker SK, Roberts CT, Kleemann D, McMillen IC. 2005. Periconceptional nutrition and the relationship between maternal body weight changes in the periconceotional period and feto-placental growth in the sheep. J Physiol 565 111-124.

Mgheni M, Christensen K. 1985. Selection experiment on growth and litter size in rabbits: II. Two-way selection response for body weight at 112 days. Acta Agric Scand 95 278-286.

Naturil-Alfonso C, Marco-Jiménez F, Jiménez-Trigos E, Saenz-de-Juano MD, Viudes-de-Castro MP, Lavara R, Vicente JS. 2015. Role of embryonic and maternal genotype on prenatal survival and foetal growth in rabbit. Reprod Domest Anim 50 312-320.

Naturil-Alfonso C, Lavara R, Vicente JS, Marco-Jiménez F. Effects of female dietary restriction in a rabbit growth line during rearing on reproductive performance and embryo quality. 2016. Reprod Domest Anim 51 114-122.

Pascual JJ, Castella F, Cervera C, Blas E, Fernández-Carmona J. 2000a. The use of ultrasound measurement of perirenal fat thickness to estimate changes in body condition of young female rabbits. Animal Science 70 435-442.

Pascual JJ, Cervera C, Fernández-Carmona J. 2000b. The effect of dietary fat on the performance and body composition of rabbits in their second lactation. Animal Feed Science and Technology 86, 191-203.

Pascual JJ, Motta W, Cervera C, Quevedo F, Blas E, Fernández-Carmona J. 2002. Effect of dietary energy source on the performance and perirenal fat thickness evolution of primiparous rabbit does. Animal Science 75, 267-279.

Pacual JJ, Savietto D, Cervera C, Baselga M. 2013. Resources allocation in reproductive rabbit does: A review of feeding and genetic strategies for suitable performance. World Rabbit Science 21, 123-144.

Picone O, Laigre P, Fortun-Lamothe L, Archilla C, Peynot N, Ponter AA, Berthelot V, Cordier AG, Duranthon V, Chavatte-Palmer P. 2011. Hyperlipidic hypercholesterolemic diet in prepubertal rabbits affects gene expression in the 
embryo, restricts fetal growth and increases offspring susceptibility to obesity. Theriogenology 75 287-299.

Piles M, Rafel O, Ramon J, Varona L. 2005. Genetic parameters of fertility in two lines of rabbits with different reproductive potential. J Anim Sci 83 340343.

Piles M, Tusell L. 2011. Genetic correlation between growth and female and male contributions to fertility in rabbit. J Animal Breeding and Genetics 129 298-305.

Ragab M, Baselga M. 2010. Inbreeding effect on reproductive traits in four maternal lines of rabbits Proceedings 9th World Congress on Genetics Applied to Livestock Production, Leipzig (Germany), p. ID083.

Rauw W, Kanis ME, Noordhuizen-Stassen EN, Grommers FJ. 1998. Undesirable side effects of selection for high production efficiency in farm animals: A review. Livestock Production 56 15-33.

Rochambeau H, Bolet $G$, Tudela F. 1994. Long-term selection. Comparison of two rabbit strains. In: Proc. 5th World Congress Genetics Applied Livestock Production, Guelph, Canada, 19 257-260.

Rommers JM, Meijerhof R, Noordhuizen JPTM, Kemp B. 2004. Effect of feeding program during rearing and age at first insemination on performances during subsequent reproduction in young rabbit does. Reprod Nutr Dev 44321 332.

Savietto D, Cervera C, Ródenas L, Martínez-Paredes E, Baselga M, García-Diego FJ, Larsen T, Friggens NC, Pascual JJ. 2014. Different resource allocation strategies result from selection for litter size at weaning in rabbit does. Animal 8, 618-628.

True MW. 2009. Circulating biomarkers of glycemia in diabetes management and implications for personalized medicine. J Diabetes Sci Technol 3 743-747. 
Verdelhan S, Bourdillon A, David JJ, Hurtaud J, Lédan L, Renouf B, Roulleau X, Salaun JM. Comparaison de deux programmes alimentaires pour la préparation des futures reproductrices. 11 èmes Journées de la Recherche Cunicole, 29-30 novembre 2005, Paris.

Vicente JS, Llobat L, Viudes-de-Castro MP, Lavara R, Baselga M, MarcoJiménez F. 2012. Gestational losses in a rabbit line selected for growth rate. Theriogenology 77 81-88.

Viudes-de-Castro MP, Vicente JS. 1997. Effect of sperm count on the fertility and prolificity traits of meat rabbits. Anim Reprod Sci 46 313-9.

Watkins AJ, Ursell E, Panton R, Papenbrock T, Hollis L, Cunningham C, Wilkins A, Perry VH, Sheth B, Kwong WY, Eckert JJ, Wild AE, Hanson MA, Osmond C, Fleming TP. 2008. Adaptative response by mouse early embryos to maternal diet protect fetal growth but predispose to adult onset disease. Biology of Reproduction 78 299-306.

Wolfenson D, Blum O. 1988. Embryonic development, conception rate, ovarian function and structure in pregnant rabbits heat-stressed before or during implantation. Animal Reproduction Science 17 259-270.

Xiccato G, Trocino A. 2010. Energy and Protein Metabolism and Requirements. In: de Blas C, Wiseman J (ed), Nutrition of the Rabbit 2nd edition. CABI, Wallingford, UK, pp. 83-118. 


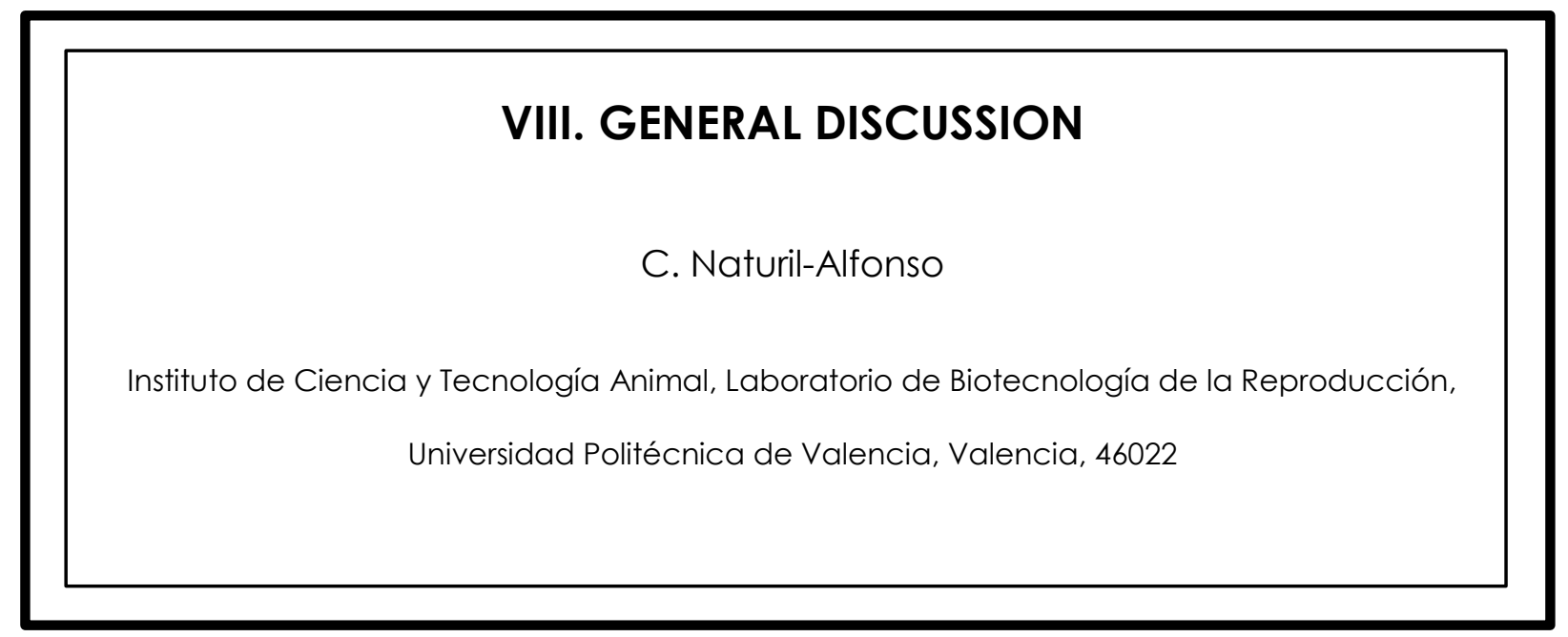





\section{GENERAL DISCUSSION}

Paternal lines are essential in the efficiency of rabbit meat production as they are employed as terminal sires in the three-way cross scheme in order to obtain crossbred animals with both reproductive and growth traits (Baselga, 2004). These lines are selected for rapid growth rate by post-weaning daily weight gain (Estany et al., 1992). So, the efficiency of rabbit meat production depends on production and reproduction traits (Baselga and Blasco, 1989; Baselga, 2004.) For these reasons, the demand for crossbred females and the use of males from specialized paternal lines is increasing apace. Although selection for growth rate has resulted in an increase in growth patterns, feed conversion ratio and tissue composition (Khalil and Al-Saef, 2008), this genetic selection process has introduced several drawbacks: long-term selection for growth rate can result in physiological, immunological and/or reproductive problems (Rauw et al., 1998).

In rabbit, as in other species, selection for growth traits shows negative correlated responses in reproductive performance (Mgheni and Christensen, 1985; Gómez et al., 1999; Ragab and Baselga, 2010; Piles and Tusell, 2011). However, estimates of genetic correlation between litter size and growth rate are low and contradictory. While some authors have reported that ovulation rate and litter size increase with body weight, suggesting a positive relationship between body weight and litter size (Bünger et al., 2005; Mgheni and Christensen, 1985; Camacho and Baselga, 1990), other studies concluded contrasting results, showing that selection for growth rate leads to a negative but low magnitude effect in fertility of paternal lines (Piles and Tusell, 2011; Vicente et al., 2003: 2012: 2013). One possible explanation is that the 
magnitude and sign of the correlations could depend on the reproductive trait studied and the population or strain under study (Rochambeau et al., 1994; Garreau et al., 2000; García and Baselga, 2002).

Line $R$ is a paternal synthetic rabbit line created in 1990 at the Universidad Politécnica de Valencia selected by individual selection on the criterion of daily weight gain from weaning to slaughter age (Estany et al., 1992). The aim of this line was to improve the growth rate, because of its negative and important genetic correlation with the conversion index (Blasco, 1989). However, as in other lines selected for growth rate, after 36 generations submitted to the genetic selection process this line presents severe reproductive problems, such as ovulation failures, implantational embryos failures and lesser litter size, related with higher implantational, gestational and fetal losses when compared with other rabbit maternal lines (Vicente et al., 2012; 2013). Several in-depth studies have examined the causes of these reproductive problems reported in this line. On the one hand, it has been reported that gestational losses may be caused by lower estradiol plasma levels in these lines at Day 12 of gestation, which could be responsible for the lower progesterone plasma levels found at Day 24 (Vicente et al., 2012). These authors suggested possible alterations in steroidogenic activity linked to the genotype of in this line. Moreover, due to the role of progesterone in pregnancy maintenance, the difference in sexual hormones appropriated to the genotype, would be responsible for the observed gestational losses. Moreover, IGF-I plasma concentrations showed to be higher in paternal lines. High levels of IGF-I have been determined as inherent to lines selected by growth rate with a beneficial effect on birth weight and postnatal growth (Clutter et al., 1995). However, IGF-I has been associated 
with an inhibitory effect on expression of nitric oxide synthase, which controls the production of nitric oxide. Both nitric oxide synthase and nitric oxide have been also related with the ovulation process and steroidogenic activity of corpora lutea in rabbits, so the high serum level of IGF-I could suggest metabolic troubles that can alter the steroid turnover or bioavailability.

Additionally, Llobat et al. (2012) reported other relevant factors such as insulin related growth factors and their receptors to be also affected in this line. Specifically, IGFII-R showed to be downregulated in embryos and endometrium of females from line $R$, which could lead to an abnormal fetal growth and development, and mainly to placentation failures. This thesis was developed in order to characterize the reproductive performance of line $\mathrm{R}$ females and to try to improve it by testing different nutritional feeding regimens after the rearing period and prior to first reproduction. With these objectives, the first two studies were focused on the reproductive performance characterization, while the last three studies were carried out to evaluate the effectiveness of feeding regimes before reproduction on the reproductive performance.

Firstly, in the first study of this thesis we aimed to determine the causal agent of the reduced reproductive performance of line $R$, making a breakdown of the influence of $R$ genotype by reciprocal embryo transfers between line $R$ and line A, which allow us to evaluate the influence of both maternal and embryonic genotype R at different stages of pregnancy (Day 14, 24 and 30), as higher gestational, embryo and fetal losses, have been found at implantation and birth. The results showed that the influence of embryonic and maternal genotypes on prenatal survival and growth, seem to change over gestation. Embryonic genotype seems to influence prenatal survival and fetal weight at 
early gestation, while maternal genotype seems to have an effect at late gestation (Day 30) on fetal losses. Additionally, at placental level, both embryonic and maternal genotype affected placental weight at mid and last gestation.

In the light of the findings of this study, fetal placenta does not seem to be responsible for deficient reproductive outcomes of line $R$, at least at gene expression level, at Day 14 and 24. Moreover, when any of the genotypes seemed to present an effect on either fetal or maternal placenta, at all times genotype $\mathrm{R}$ benefited from higher fetal placental weight at Day 24 for $R / R$ genotype and higher maternal placental weight at Day 14 and at Day 30 for $R$ and R/R genotype, respectively. Nevertheless, focusing on prenatal losses, according to previous studies that reported higher implantational and gestational losses in this line (Vicente et al., 2012; 2013), both embryonic and maternal genotype seemed to play a role, with lower outcomes for genotype $R$ when compared with genotype A. Implantational rate at Day 14 was influenced by embryonic genotype, while the interaction of embryonic and maternal genotypes resulted in lower live fetuses rate at Day 24 for the $R / R$ genotype, and only maternal genotype affected prenatal survival rate at Day 30 with lower figures for genotype R. Therefore, the low reproductive efficiency characterizing line $\mathrm{R}$ seems to be a consequence of both embryonic and maternal genotypes, with a lower implantational and live fetus rate for line $\mathrm{R}$ than for maternal line A.

For this reason, we conducted the second experiment to determine if the causes of the low reproductive performance have their origin in the female, focusing on the initial steps of the reproductive process, the ovulation system. 
Previous studies working in this rabbit line have reported alterations in ovulation frequency and ovulation rate in females of line $R$ when compared with a maternal line (Vicente et al., 2012; 2013). Thus, in this work we aimed to evaluate if an inadequate neuroendocrine reflex at hypothalamus-pituitary system is the cause of the ovulation induction failures in these females. When we compared the ovulation failures of females naturally mated and artificially inseminated, we found out that while all Al females ovulated, $32 \%$ of the natural mated females failed in ovulation, according to previous reports in this line (30\%, Vicente et al., 2012). As widely reported in rabbit production, when does are $\mathrm{Al}$ they are treated with $\mathrm{GnRH}$ analogues to induce ovulation, and none of them fail. In this connection, we ruled out problems due to LH secretion or the absence of follicular LH receptors, so we proposed that ovulation deficiencies could be a consequence of failures in nervous stimuli to the hypothalamus or an inadequate neuroendocrine reflex in the hypothalamus-pituitary system to trigger the appropriate GnRH response. In fact, although not significant, reduced concentrations of mean LH were detected in NM females compared with GnRH treated females, leading to lower ovulation rate (also observed by Balasubramanian et al., 2012) and consequently resulting in lower global pregnancy rates observed (34.4\% vs. $66.7 \%$ for NM and Al, respectively).

On the other hand, the analysis of body conditions and metabolic hormones and metabolites related to energy balance reported higher leptin, BOHB and body weight in non-ovulated NM females than in ovulated ones. Other authors have related elevated leptin levels and high weight with a reduced LH production by the pituitary (Duggal et al., 2000; Brecchia et al., 2006; Cardinali et al., 2008; Balasubramanian et al., 2012). 
In view of all of these outcomes, with low reproductive efficiency and alterations in body condition and metabolic hormones and metabolites, as mentioned above, the last three experiments were focused on the evaluation of the possible benefits on different nutritional regimes applied to females of line $\mathrm{R}$ after rearing period and previous to mating. It is widely known that availability of food and the actions of intaken and digested food have profound and complex effects upon numerous neuroendocrine axes in the body with reproductive consequences.

Nutritional balance is calculated from the difference between the nutritional supply from the food and the requirements of the animal (Fortun-Lamothe, 2006). Based on the equation proposed by Xiccato and Trocino (2010): $340 \mathrm{~kJ}$ $\mathrm{day}^{-1} \mathrm{~kg}^{-1} \mathrm{LW}^{0.75}$, the nutritional requirements for these females could be satisfied by $130 \mathrm{~g} /$ day with a commercial rabbit diet on dry matter basis: $17.5 \%$ crude protein, 3.5\% ether extract, $16.7 \%$ crude fibre, $2938 \mathrm{kcal} / \mathrm{kg})$. However, in the literature review we realized that in a previous study with the New Zealand White rabbit strain (a maternal line with lower ingestion and growth rate) the control group was fed with 150g/day of a $2490 \mathrm{kcal}$ DE/kg (Daoud et al., 2012). Thus, the hypothesis was that the nutritional regime is not enough to cope with the needs during the pubertal periods of those females selected for growth rate, causing a long-term nutrient deficiency which leads to the subsequent reproductive problems. Indeed, maternal nutrition is one of the main factors affecting developmental competence of mammalian oocytes and embryos (Moussa et al., 2015).

Thus, in the third experiment of the thesis we analysed how the feeding regimen (ad libitum or restricted) after rearing period and prior to reproduction could 
affect the hypothalamus-hypophysis axis and oocyte quality by gene expression analysis. However, no differences were found in the hypothalamushypophysis microarray analysis between females fed ad libitum or restricted, discarding alterations in the central nervous system which would explain the ovulation failures. Therefore, peripheral mechanisms such as failure in the nervous stimuli to the hypothalamus-hypophysis system may be the cause of the ovulation failures, which may the object of study in future works.

On the other hand, previous studies of the effects of under- or overnutrition on embryo development reported initial effects at ovarian level (Wakefield et al., 2008; Igosheva et al., 2010; Luzzo et al., 2012). Nutritional support is crucial to provide the follicular cells with sufficient energy source to complete the growth and developmental programmes (Moussa et al., 2015). Our results manifested that oocytes from different feeding regimens present differential gene expression of an essential gene responsible for maternal mRNA transcription and translation in the fully growth oocyte (MSY2). These alterations on at least one of the group of genes studied indicate that the oocyte is altered in some undetermined way, leading to alterations in embryonic development which could explain the differences in global gestational losses and fetal growth reported in this line.

Therefore, the alterations on ovulation and the prenatal losses reported in these females may not be a consequence of the hypothalamus-hypophysis themselves; it may the consequence of nutritionally derived factors which target hypothalamus and pituitary and are responsible for down-regulation of GnRH secretion and reduced synthesis of $\mathrm{LH}$, as well as the effects on oocyte and subsequent alterations in embryo development (García-García et al., 
$2011)$. In fact, MSY2 dysfunctions have shown to be involved in main processes such as oocyte maturation and activation, meiotic spindle alterations and deficient protein synthesis and total amount of mRNA in fully growth oocytes (Yu et al., 2004), which may explain the drop in fertility, litter size and developmental arrest during pre- or post-implantatory embryo development.

Consequently, these effects on embryo development were examined in the fourth study. Thus, in this study we focused on the relevance of the embryo genotype which we previously determined (chapter 1) that influenced prenatal survival and fetal weight at early gestation, taking into account that the genotype of the embryos is only relevant in embryo survival in a favourable maternal environment (Mocé et al., 2004). In the first experiment of this work we concluded that feeding regimen could alter the fertilization process, uterine environment and/or the oocyte, which would be manifested at the embryo level. For this reason, in the second experiment we produced 24-hour embryos for line $\mathrm{R}$ females and transferred to recipient females from a maternal line due to the results of chapter 1, which showed that the maternal environment of Line A females was better for embryo development and fetal survival than uterine environment of line R. Although we did not detect differences in ovulation and embryo recovery rate between ad libitum and restricted donor females, according to other studies (Kwong et al., 2000; Tripp et al., 2000; Cardinali et al., 2008), differences were found in embryo and fetal development. These differences were established from implantation to birth, with lower gestational and higher growth of ad libitum derived fetuses than restricted ones. Although previous studies carried out with rabbits have reported opposite results to ours, without a relation between restricted feed restriction on post-implantation 
losses and fetal viability (Petrere et al., 1993; Cappon et al., 2005), the difference between these works and ours is that our study is characterized by the use of a paternal line, while the others were performed with a maternal line.

Our findings confirm that fetal growth is altered due to the feeding regimen of the donor doe prior to mating, so suggest that the alterations detected in MSY2 expression in chapter 3 have real consequences in the subsequent embryo and fetal developmental trajectory, which are established during oocyte development and maturation.

Therefore, the final chapter of this thesis attempted to determine if different ingestion regimes have an effect on the reproductive life of the females submitted to a semi-intensive reproductive system. As we determined in chapters 3 and 4 , the nutritional regimen prior to mating has been shown to influence oocyte characteristics, determining the future development of the early embryo and the effectiveness of the reproductive process. Thus, this effect on the metabolism and reproductive performance was analysed in rabbit does selected for growth rate. Results reported some differences in body weight and NEFAs, BOHB and leptin concentrations at different moments of the period studied. Although leptin has been established as a key factor in the nutritional-reproductive pathway, leptin differences were only found at third or subsequent gestations. Leptin concentrations have been related to GnRH/LH secretory system regulation but this role may depend upon the current overall nutritional status (Brecchia et al., 2006). This may explain the absence of differences in gene expression in the hypothalamus-hypophysis seen in the third chapter of this thesis, when we try to explain the causes of ovulation failures revealed in the second chapter by a microarray analysis of the ad libitum and 
restricted hypothalamus-hypophysis. However, despite these occasional differences and contrary to the expected results in light of the previous results of the thesis, no differences were detected in the productive life performance (fertility, prolificacy and productivity).

Overall, Arias-Álvarez et al. (2009) reported that the metabolic status of the female is associated with reproductive outcomes and determines the oocyte developmental competence. So, the nutritionally derived factors target both hypothalamus and pituitary. Consequently, as folliculogenesis is controlled by gonadotropins from the pituitary, it affects the ovulation process. Additionally, alterations in LH secretions, a consequence of the alterations in the hypothalamus-hypophysis axis, may have an impact on oocyte quality (Labreque et al., 2014). Therefore, these parameters could affect the competence of the gamete before fertilization, which influences oocyte maturation and lastly embryo development (Arias-Álvarez et al., 2009) affecting the overall reproductive outcomes.

In this connection, we hypothesized that it could be that the restriction to which these females are submitted leads to a slightly negative energy balance in females with an effect on reproduction performance which starts at oocyte level. In fact, the reproductive performance of animals is highly altered when the nutritional regimen is negative (Fortun-Lamothe, 2006). Nevertheless, although differences were found at oocyte level which seem to be relevant in embryonic and fetal development and growth, chapter 5 showed no improvement in reproductive performance when line $\mathrm{R}$ embryos from different feeding regimens developed in the maternal environment of line $R$. In this regard, Theilgaard (2006) suggested that there is a genetic component 
controlling size and mobilization of body fat, with a high priority in safeguarding body reserves of the females. So, we suggest that the genetic characteristics of this line prioritize their own maintenance to the offspring, accommodating their own demands.

Therefore, other reproductive and nutritional strategies should be tested in order to carry out an adjusted management of rabbit females selected by growth rate, which must be adapted to their specific characteristics. Thus, these strategies would enhance the females to achieve coherent reproductive outcomes. Additionally, other studies focused on the direct relationship between selection for growth rate and reproductive performance should be carried out in order to consider this factor in subsequent line foundations.

\section{LITERATURE CITED}

Arias-Álvarez M, García-García RM, Rebollar PG, Nicodemus N, Revuelta L, Millán P, Lorenzo PL. 2009. Effects of a lignin-rich fiber diet on productive, reproductive and endocrine parameters in nulliparous rabbit does. Livest Sci 123 107-115.

Balasubramanian P., Jagannathan L., Subramanian M., Gilbreath E.T., MohanKumar P.S., MohanKumar S.M.J. 2012. High fat diet affects reproductive functions in female diet-induced obese and dietary resistant rats. J Neurondocrinol 24 748-755.

Baselga M, Blasco A, 1989. Mejora genetica del conejo de produccion de carne. Ed Mundi-Prensa Libros SA, Madrid.

Baselga, M. 2004. Genetic improvement of meat rabbits. Programmes and diffusion. In: Proc. 8th World Rabbit Congress, Puebla, Mexico, 1-13.

Blasco A. 1989. Genética y nutrición del conejo. In C. de Blas Alimentación del conejo. Ediciones Mundi, Prensa, Madrid. 
Brecchia G, Bonanno A, Galeati G, Federici C, Maranesi M, Gobbetti A, Zerani M, Boiti C. 2006. Hormonal and metabolic adaptation to fasting: Effects on the hypothalamic-pituitary-ovarian axis and reproductive performance of rabbit does. Domest Anim Endocrinol 31 105-122.

Bünger L, Lewis RM, Rothschild MF, Blasco A, Renne U, Simm G. 2005. Relationships between quantitative and reproductive fitness traits in animals. Phil Trans R Soc B 360 1489-1502.

Camacho J, and Baselga M. 1990. Genetic correlation between reproductive and growth traits in rabbits. In Proc: 4th World Congress on Genetics Applied to the Livestock Production, Edinburgh, Scotland 16:366-369.

Cappon GD, Fleeman TL, Chapin RE, Hurtt ME. 2005. Effects of feed restriction during organogenesis on embryo-fetal development in rabbit. Birth Defects Research 74 424-430.

Cardinali R, Dal Bosco A, Bonanno A, Di Grigoli A, Rebollar PG, Lorenzo PL, Castellini C. 2008. Connection between body condition score, chemical characteristics of body and reproductive traits of rabbit does. Livest Sci 116209 215.

Clutter AC, Spicer LJ, Woltmann MD, Grimes RW, Hammond JM, Buchanan DS. 1995. Plasma growth hormone, insulin-like growth factor I, and insulin-like growth factor binding proteins in pigs with divergent genetic merit for postweaning average daily gain. J Anim Sci 73 1776-1783

Daoud NM, Mahrous KF, Ezzo OH. 2012. Feed restriction as a biostimulant of the production of oocytes, their quality and GDF-9 gene expression in rabbit oocytes. Anim Reprod Sci 136 121-127.

Duggal PS, Van Der Hoek KH, Milner CR, Ryan NK, Amstrong DT, Magoffin DA, Norman RJ. 2000. The in vivo and in vitro effects of exogenous leptin on ovulation in the rat. Endocrinology 141 1971-1976.

Estany J, Camacho J, Baselga M, Blasco A. 1992. Selection response of growth rate in rabbits for meat production. Genet Sel Evol 24 527-537. 
Fortun-Lamothe L. 2006. Energy balance and reproductive performance in rabbit does. Anim Repr Sci 93 1-15.

García ML and Baselga M. 2002. Estimation of correlated response on growth traits to selection in litter size of rabbits using a cryopreserved control population and genetic trends. Livest Prod Sci 78 91-98.

García-García RM, Rebollar PG, Arias-Álvarez M, Sakr OG, Bermejo-Álvarez P, Brecchia G, Gutierrez-Adan A, Zerani M, Boiti C, Lorenzo PL. 2011 . Acute fasting before conception affects metabolic and endocrine status without impacting follicle and oocyte development and embryo gene expression in the rabbit. Reprod Fertil Dev 23 759-768.

Garreau H, Szendro ZS, Larzul C, Rochambeau De H. 2000. Geentics parameters and genetic trends of growth and litter sizr in the White Phannon Breed. In: Proc. 7th World Rabbit Congress, Valencia, Spain, 403-408.

Gomez EA, Baselga M, Rafel O, Garcia ML, Ramon J. 1999. Selection, diffusion and performances of six Spanish lines of meat rabbit. Cahiers Options Mediterraneennes 41 147-152.

Igosheva N, Abramov AY, Poston L, Eckert JJ, Fleming TP, Duchen MR, McConnell J. 2010. Maternal diet-induced obesity alters mitochondria activity and redox status in mouse oocytes and zygotes. PLoS One 5 el0074.

Khalil MH, Al-Saef AM. Methods, criteria, techiniques and genetique responses for rabbit selection: A review. In: 9 th World Rabbit Congress - June 10-13, 2008 - Verona - Italy.

Kwong WY, Wild AE, Roberts P, Willis AC, Fleming TP. 2000. Maternal undernutrition during preimplantation period of rat development causes blastocyst abnormalities and programming of postnatal hypertension. Development 127 4195-4202.

Labreque R, Vigneault C, Blondin P, Sirard MA. 2014. Gene expression analysis of bovine oocytes at optimal coasting time combined with GnRH antagonist during the no-FSH period. Theriogenology 81 1092-1100. 
Luzzo KM, Wang Q, Purcell SH, Chi M, Jimenez PT, Grindler N, Schedl T, Moley $\mathrm{KH}$. 2012. High fat diet induced developmental defects in the mouse: oocyte meiotic aneuploidy and fetal growth retardation/brain defects. PLoS One 7 e49217.

Mgheni M, Christensen K. 1985. Selection experiment on growth and litter size in rabbits: II. Two-way selection response for body weight at 112 days. Acta Agric Scand, 95:278-286.

Mocé ML, Santacreu MA, Climent A, Blasco A. 2004. The effect of divergent selection for uterine capacity on prenatal survival in rabbits: Maternal and embryonic genetic effects. J Anim Sci 82 68-73.

Moussa M, Shu J, Zhang XH, Zeng F. 2015. Maternal control of oocyte quality in cattle "a review". Anim Reprod Sci 155 11-27.

Petrere JA, Rohn WR, Grantham II LE, Enderson JA. 1993. Food restriction during organogenesis in rabbits: effects on reproduction and the offspring. Fundam Appl Toxicol 21 517-522.

Piles M and Tusell L. 2011. Genetic correlation between growth and female and male contributions to fertility in rabbit. J Anim Breed Genet 129 298-305.

Ragab M., Baselga M. 2010. Inbreeding effect on reproductive traits in four maternal lines of rabbits. Proc: 9th World Congress on Genetics Applied to Livestock Production, 1-6 August, 2010. Leipzig, Germany. p. ID083

Rauw W, Kanis ME, Noordhuizen-Stassen EN, Grommers FJ. 1998. Undesirable side effects of selection for high production efficiency in farm animals: A review. Livest Prod Sci 56 15-33.

Rochambeau De H, Bolet G, Tudela F. 1994. Long term selection. Comparison of two rabbit strains. In: Proc. 5th World Congress on Genetics Applied to Livestock Production, Guelph 19 257-260.

Theilgaard P. 2006. Prolificacy, reproductive longevity and body reserves in female rabbits examined using selection lines. Ph.D. Thesis. Universitat Politècnica de València. Spain; pp. 126. 
Tripp MW, JU JC, Hoagland TA, Riesen JW, Yang X, Zinn SA. 2000. Influence of somatotropin and nutrition on bovine oocyte retrieval and in vitro development. Theriogenology 53 1581-1590.

Vicente JS, Viudes-de-Catro MP, García ML, Baselga M. 2003. Effect of rabbit line in a cryopreservation program by vitrification. Reprod Nutr Develop 43 147153.

Vicente JS, Llobat L, Viudes-de-Castro MP, Lavara R, Baselga M, MarcoJiménez F. 2012. Gestational losses in a rabbit line selected for growth rate. Theriogenology 77 81-88.

Vicente JS, Llobat L, Jiménez-Trigos E, Lavara L, Marco-Jiménez F. 2013. Effect of emrbyonic and maternal genotype on embryo and foetal survival in rabbit. Repro Dom Anim 48 402-406.

Wakefield SL, Lane M, Schulz SJ, Hebart ML, Thompson JG, Mitchell M. 2008. Maternal supply of omega-3 polyunsaturated fatty acids alter mechanisms involved in oocyte and early embryo development in the mouse. Am J Physiol Endocrinol Metab 294 E425-E434.

Xiccato, G Trocino A. 2010. Energy and Protein Metabolism and Requirements. In: de Blas C, Wiseman J (ed), Nutrition of the Rabbit 2nd edition. CABI, Wallingford, UK, pp. 83-118.

Yu J, Deng M, Medvedev S, Yang J, Hecht NB, Schultz RM. 2004. Transgenic RNAi-mediated reduction of MSY2 in mouse oocytes results in reduced fertility. Dev Biol 268 195-206. 



\title{
IX. CONCLUSIONS
}

\author{
C. Naturil-Alfonso
}

Instituto de Ciencia y Tecnología Animal, Laboratorio de Biotecnología de la Reproducción, Universidad Politécnica de Valencia, Valencia, 46022 



\section{CONCLUSIONS}

In $\mathrm{R}$ females from paternal rabbit lines, both maternal and embryonic genotypes are relevant in the reproductive performance of the female, although their roles change over the course of gestation.

The ovulation failures of females from line $\mathrm{R}$ seem to come as a consequence of a reduction in plasma $\mathrm{LH}$ concentrations. These alterations may be due to the altered metabolic status and not to any alteration in the hypothalamushypophysis axis.

In fact, the effect of different nutritional regimes (ad libitum and restricted) after rearing period and prior to first mating/Al did not reveal significant changes in hypothalamus-hypophysis gene expression, but significant differences in oocyte gene expression in a group of genes were found in oocytes from the different groups. These differences established at the oocyte level were inherited and also manifested at embryonic level, as when embryos formed ad libitum were developed in recipient maternal line females, they showed lower gestational losses and higher fetal growth than restricted ones. Nevertheless, under a common semi-intensive farm production system females submitted to the different feeding regimens did not show any difference in fertility rate without improving the reproductive performance of this line, although minor differences were found at metabolic level. 